\title{
A systematic review of participatory scenario planning to envision mountain social-ecological systems futures
}

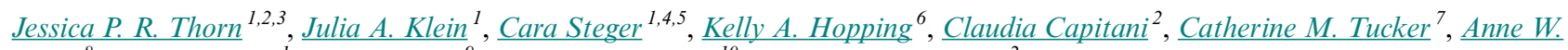
${\underline{\text { Nolin }^{8}}}^{8}, \underline{\text { Robin S. Reid }}^{1}, \underline{\text { Roman Seidl }}^{9}, \underline{\text { Vishwas S. Chitale }}^{10}{\text { and } \text { Robert Marchant }^{2}}^{2}$

\begin{abstract}
Mountain social-ecological systems (MtSES) provide crucial ecosystem services to over half of humanity. However, populations living in these highly varied regions are now confronted by global change. It is critical that they are able to anticipate change to strategically manage resources and avoid potential conflict. Yet, planning for sustainable, equitable transitions for the future is a daunting task, considering the range of uncertainties and the unique character of MtSES. Participatory scenario planning (PSP) can help MtSES communities by critically reflecting on a wider array of innovative pathways for adaptive transformation. Although the design of effective approaches has been widely discussed, how PSP has been employed in MtSES has yet to be examined. Here, we present the first systematic global review of single- and multiscalar, multisectoral PSP undertaken in MtSES, in which we characterize the process, identify strengths and gaps, and suggest effective ways to apply PSP in MtSES. We used a nine-step process to help guide the analysis of 42 studies from 1989 screened articles. Our results indicate a steady increase in relevant studies since 2006, with 43\% published between 2015 and 2017. These studies encompass 39 countries, with over $50 \%$ in Europe. PSP in MtSES is used predominantly to build cooperation, social learning, collaboration, and decision support, yet meeting these objectives is hindered by insufficient engagement with intended end users. MtSES PSP has focused largely on envisioning themes of governance, economy, land use change, and biodiversity, but has overlooked themes such as gender equality, public health, and sanitation. There are many avenues to expand and improve PSP in MtSES: to other regions, sectors, across a greater diversity of stakeholders, and with a specific focus on MtSES paradoxes. Communicating uncertainty, monitoring and evaluating impacts, and engendering more comparative approaches can further increase the utility of PSP for addressing MtSES challenges, with lessons for other complex social-ecological systems.
\end{abstract}

Key Words: alpine; adaptive transformation; coupled natural-human systems; highlands; montane; planetary boundaries; stewardship; sustainability science; transdisciplinary

\section{INTRODUCTION}

Mountain social-ecological systems (MtSES; Box 1) encompass approximately $30.5 \%$ of all land (Karagulle et al. 2017, Sayre et al. 2018) and $23 \%$ of the Earth's total forest cover (Körner and Ohsawa 2006). Characterized by high levels of biodiversity and endemism, they support an estimated $85 \%$ of the world's amphibian, bird, and mammal species (Rahbek et al. 2019a). Based on 2017 population data, MtSES are inhabited by up to $28.3 \%$ (2.21 billion) of the global human population (Karagulle et al. 2017, Rose et al. 2018), many of whom are among the world's poorest people (Körner et al. 2017). One in two rural mountain dwellers faces food insecurity, and they have less access to infrastructure and services compared to lowland populations (FAO 2015, Manuelli et al. 2017, FAO and UNCCD 2019). Many local communities rely on the ecosystem services from MtSES regions, such as timber, natural hazard regulation, and tourism, for their subsistence and livelihoods (Harrison et al. 2010). Beyond these MtSES communities, more than half of humanity relies on the freshwater originating in MtSES (Liniger and Weingartner 1998). Indeed, the world's 10 longest rivers have headwaters in MtSES, e.g., the Yangtze River on the Tibetan Plateau and Congo River in the East African Rift (Encalada et al. 2019).
Central to the well-being and survival of much of humanity, MtSES are confronted by climate change, biodiversity loss, land use conversion, and other long-term social-economic challenges (Cuni-Sanchezet al. 2018, Hagedorn et al. 2019, Klein et al. 2019a, $b$, Rahbek et al. 2019b, Steger et al. 2020). For instance, the rate of warming is amplified as elevation increases (Hagedorn et al. 2019), resulting in higher exposure to climate change in MtSES than the global average or in lower elevation regions (Pepin et al. 2015, IPCC 2018). Such warming can lead to rising cloud bases or reduced overall cloud immersion, which plays an important ecological role in many tropical montane cloud forests by creating isolated patches of habitat with more fog and mist, high soil moisture and carbon storage, and unique species (Bruijnzeel et al. 2011, Helmer et al. 2019). In higher elevation MtSES, glacial retreat has been rapid, with societal implications (Carey et al. 2017, Nyima and Hopping 2019). In recent decades, many MtSES have also experienced destabilizing demographic fluxes caused by seasonal migration, permanent rural exodus, amenity inmigration, aging, restructured market relationships, industrial developments, and the abandonment of economic activities (Glorioso and Moss 2007, Park and Pellow 2011). Therefore, understanding the challenges to present and future sustainability of MtSES is critical to plan for potential trajectories of change, not only for the rural communities that have developed in relative

\footnotetext{
${ }^{1}$ Department of Ecosystem Science and Sustainability, Colorado State University, Fort Collins, CO USA, ${ }^{2}$ York Institute of Tropical Ecosystems, Department of Environment and Geography, University of York, York, UK, ${ }^{3}$ African Climate and Development Initiative, University of Cape Town, Cape Town, South Africa, ${ }^{4}$ Graduate Degree Program in Ecology, Colorado State University, Fort Collins, CO USA, ${ }^{5}$ Natural Resource Ecology Laboratory, Colorado State University, Fort Collins, CO USA, ${ }^{6}$ Human-Environment Systems, Boise State University, Boise, ID USA, ${ }^{7}$ Department of Anthropology, University of Florida, Gainesville, FL USA, ${ }^{8}$ University of Nevada, Reno, NV USA, ${ }^{9}$ Leibniz University Hannover, Institute for Radioecology and Radiation Protection, ${ }^{10}$ International Centre for Integrated Mountain Development, Kathmandu, Nepal
} 
isolation and whose survival and cultures depend directly on MtSES resources, but also for the lowland communities that depend on resources flowing from these ecosystems (FAO 2015).

Yet, planning for sustainable, equitable transitions in MtSES is a daunting task considering the range of uncertainties and the peculiar conditions of MtSES, referred to as paradoxes (see Klein et al. 2019b; Box 2). Uncertainties in future planning are associated with a high occurrence of cross-scale interactions in MtSES, such as cascading hydrological changes at watershed/ basin scales (Jaeger et al. 2017) and often mismatched supply and demand of ecosystem services across elevational gradients (Brunner et al. 2016). Uncertainties in possible futures are highly contingent and nonlinear, and are affected by events and decisions that are themselves often highly unpredictable (IPBES 2016). Planning for transitions is further complicated in that decisions based on a specific prediction can lead to unintended consequences for sustainability and equity, particularly when scientists assessing conservation priorities do not use participatory approaches, have different values than MtSES stakeholders, and these hidden value-judgements are not made explicit (Huber et al. 2013, Seidl 2015). Poorly defined problems related to resource allocation can also arise from a lack of scientific advice, e.g., the Green Revolution in the Himalayas (Rasul 2010, Game et al. 2013).

\section{Box 1: Definition of MtSES.}

MtSES are typically characterized by high kinetic energy, steep vertical gradients, and are more likely than nonmountain regions to experience multihazards such as earthquakes, landslides, avalanches, flash floods, erosion, and fire (Gardner and Dekens 2007, Zimmerman and Keiler 2015, Klein et al. 2019b). One recent attempt to characterize global mountain extent is the K3 geospatial raster, which uses three classification parameters (slope, relative relief, and profile) to define four mountain classes of plains, hills, mountains, and tablelands at 250-m resolution (Karagulle et al. 2017, Sayre et al. 2018). However, different definitions of mountains have been proposed for various contexts and countries. This is in part because definitions established for MtSES boundaries are determined not only by geological conditions and landforms but also by climatic and hydrological conditions, ecosystem patterns, animal and plant distributions, and human activities, e.g., mountaineering, mining, and leisure (Körner and Ohsawa 2006, Körner et al. 2017). Definitions also diverge because the biophysical boundaries of MtSES can be difficult to align with administrative or economic boundaries (Price et al. 2018). In this paper, we use the K3 definition to analyze global mountain distributions in relation to population density, because it is the most recent, accurate, and finest resolution dataset available. However, our concept of MtSES is more holistic than the biophysical K3 definition, encompassing complex adaptive systems consisting of interacting social-ecological processes and unique challenges (Box 2).

Participatory scenario planning (PSP) can help overcome some of these challenges for sustainable and equitable transitions in MtSES by using novel combinations of expertise to creatively envision and critically reflect on a wider array of innovative pathways for adaptive transformation (van der Heijden 1996, Kok and van Vliet 2011, Bai et al. 2016). The central idea of PSP is to consider a range of diverse, plausible futures, e.g., events, conditions, and uncertainties, rather than focusing on the prediction of a single or most probable outcome (Wilkinson and Eidenow 2008). Through close collaboration with diverse stakeholders, the process can build consensus, trust, and cooperation among participants, and improve the legitimacy and understanding of scenario outputs (Barnaud et al. 2007, Kohler et al. 2017, Allington et al. 2018). PSP offers a valuable means to bridge the science-policy interface, by accommodating varied perspectives, needs, expectations, and values, and by coproducing an integrated understanding of landscape and socioeconomic dynamics (Peterson et al. 2003, Wilkinson 2009, IPBES 2016).

PSP can also help address some of the challenges created by MtSES paradoxes (Box 2). For example, PSP can increase decision makers' abilities to identify when, where, and why scarcities occur in MtSES, e.g., water availability due to changing snowpack melt (Jaeger et al. 2017). PSP can encourage MtSES adaptation to global change by examining system drivers, identifying the underlying mechanisms most relevant for unpredictable futures, and evaluating which interventions are most appropriate (Soliva and Hunziker 2009, Fischler et al. 2016). At the same time, local knowledge that emerges through PSP can help fill critical gaps in understanding the functioning of MtSES when data are scarce (Oteros-Rozas et al. 2015). PSP is an opportunity not only to open local knowledge systems to global trends that may affect isolated and remote MtSES, e.g., through telecoupling, but also introduce local knowledge to those living outside MtSES, mainstream it into decision-making processes (Capitani et al. 2019), and assess trade-offs between key ecosystem services such as water, biodiversity, and carbon (Capitani et al. 2019). PSP may be a better tool for addressing MtSES challenges than other methods, e.g., participatory GIS, integrated assessment models, and ethnographic or economic valuations, because of the explicit attempt to not only help people to understand, prepare, and adapt more effectively to future events, but also to develop actionable pathways to challenge and change these events (Kahane 2012).

\section{Box 2: MtSES paradoxes}

Klein et al. (2019b) identified a set of "paradoxes" that summarize common challenges in MtSES. This is one way to think about the interacting complexities and surprising, contradictory aspects of MtSES that may reveal opportunities for sustainable transitions. These paradoxes (P) are as follows: (P1) MtSES tend to be resource rich but income poor; (P2) Policies affecting MtSES are often made by outsiders with limited understanding of local dynamics; (P3) MtSES are remote but vulnerable to global change; (P4) MtSES experience destabilizing in- and outmigration; (P5) Although often difficult to access, MtSES attract diverse actors with substantive institutional, distributional, or socio-political inequities, which pose challenges for representative decision making; and (P6) To capture their high spatio-temporal complexity, MtSES require fine-scale data for effective resource management, yet these data are often lacking. 
The limitations of PSP, like any approach, should be acknowledged (e.g., see Hubacek and Rothman 2005). For example, when bringing together a diversity of stakeholders, competing interests can trigger conflicts, and facilitators need to be trained to manage inherent power dynamics (Oteros-Rozas et al. 2015). In scenario generation, the assumptions underlying value-choices are often not explicitly reported, even though there is the potential to be transparent about values (Rawluk et al. 2018), which can lead to certain values or worldviews dominating the scenarios. It is difficult to assess the influence of PSP on decision making because the process results in multiple strategies. Additionally, there is the danger that decisions based on PSP can downplay uncertainty or lack sufficient evidence to inform robust policy decisions (Reed et al. 2013).

Although the design of effective PSP approaches has been discussed in many research fields (e.g., van Vuuren et al. 2012, Kok et al. 2017), no systematic assessment to date has evaluated how PSP has been employed in MtSES worldwide. Previous PSP synthesis efforts have focused on particular sectors, e.g., climate change adaptation (Star et al. 2016), methods (e.g., Reed et al. 2013), typological approaches that distinguish between phases in the PSP process (e.g., van Notten et al. 2003), or placed-based PSP for all SES (Oteros-Rozas et al. 2015). Here, we systematically review peer-reviewed and nonpeer-reviewed literature of singleand multiscalar, multisectoral PSP undertaken in MtSES globally. We use a systematic review approach because this rigorous approach can be a starting point for generating new knowledge and planning (Gleeson et al. 2016). Specifically, we investigate three questions: (1) How has PSP been employed in MtSES, with what geographic, temporal, and thematic foci? (2) What are the benefits of PSP as applied to MtSES? (3) What are key gaps of PSP in MtSES, and what can be learned from PSP in other contexts?

\section{METHODS}

Search strategy

A systematic review of the literature on PSP in MtSES followed methods established by the Collaboration for Environmental Evidence Guidelines and Standards for Evidence Synthesis in Environmental Management (CEE 2013). This method is used widely and recognized as a standard for accessing, appraising, and synthesizing scientific information to inform decision making. To minimize bias, improve reporting, and ensure a highquality and comprehensive systematic review, we followed the preferred reporting items for systematic reviews and metaanalyses (PRISMA) checklist (Moher et al. 2009). This checklist corresponds to the iterative stages of our structured review process (Fig. 1); PRISMA helps authors ensure a transparent and complete reporting of their review process by using systematic and explicit methods to identify, select, and critically appraise relevant research, and to collect and analyze data from the studies included in the review. Following these protocols ensured rigor, objectivity, verifiable procedures, and clarity of the study design (CEE 2013). We developed the search strategy for finding MtSES PSP studies through (a) discussions with researchers and stakeholders at a workshop on participatory modeling in MtSES; (b) consultations with an advisory board of scientific experts in PSP in MtSES (Appendix 1) throughout 2017-2018; and (c) working with an experienced environmental librarian.
Sources of publications and key search terms

We conducted systematic searches of peer-reviewed and nonpeerreviewed literature in bibliographic databases, key international journals, specialist organizations, online databases, and search engines, as well as via an open webinar with the extended Mountain Sentinels Collaborative Network and consultations with its advisory board (between 22 April and 8 November 2017). Five bibliographic databases were searched: Thomson Reuter's (formally ISI) Web of Science ${ }^{\mathrm{TM}}$, Core Collection Academic Search Premier, CAB Abstracts published by CAB International (1973-present), AGRICOLA National Agricultural Library and Citation Database and Social Sciences Full Text (H. W. Wilson). A repeat search on 4 November 2019 in Web of Science found only three additional studies published since the initial review. Five key international e-journals whose topic areas closely aligned with the research question were hand searched. Google Scholar was used to retrieve the first 200 search results and we checked for studies not captured in the above databases. Fourteen subjectspecific web sites including nongovernmental organizations, public and research institutions, and online databases were searched for reports, conference proceedings, policy briefs, book chapters, and individual research papers (Table 1). To assist in screening nonpeer-reviewed literature, text extraction software was used to identify key words related to the research questions.

Table 1. Specialist organizations and online databases searched in the systematic review. Web site links were correct as of 12 May 2020 .

\begin{tabular}{|c|c|c|}
\hline \multicolumn{2}{|c|}{ No.Organization } & \multirow{2}{*}{$\begin{array}{l}\text { Web site } \\
\text { http://mountain.org/publications/ }\end{array}$} \\
\hline 1 & $\begin{array}{l}\text { The Mountain Institute } \\
\text { (TMI) }\end{array}$ & \\
\hline 2 & $\begin{array}{l}\text { Mountain Research Initiative } \\
\text { (MRI) }\end{array}$ & $\begin{array}{l}\text { https://www.mountainresearchinitiative. } \\
\text { org/ }\end{array}$ \\
\hline 3 & $\begin{array}{l}\text { United Nations Environment } \\
\text { Programme (UNEP) }\end{array}$ & http://www.unep.org/publications/ \\
\hline 4 & $\begin{array}{l}\text { Interdisciplinary Mountain } \\
\text { Research }\end{array}$ & $\begin{array}{l}\text { http://www.mountainresearch.at/index. } \\
\text { php/en/projects }\end{array}$ \\
\hline 5 & $\begin{array}{l}\text { International Centre for } \\
\text { Integrated Mountain } \\
\text { Development (ICIMOD) }\end{array}$ & http://www.icimod.org/himaldoc \\
\hline 6 & Stockholm Resilience Centre & $\begin{array}{l}\text { http://www.stockholmresilience.org/ } \\
\text { publications.html }\end{array}$ \\
\hline 7 & $\begin{array}{l}\text { Social-Ecological Systems } \\
\text { (SES) Library }\end{array}$ & https://seslibrary.asu.edu/ \\
\hline 8 & $\begin{array}{l}\text { International Commission for } \\
\text { the Protection of the Alps } \\
\text { (CIPRA) }\end{array}$ & http://www.cipra.org/en/publications \\
\hline & EURAC Research & $\begin{array}{l}\text { http://www.eurac.edu/en/research/ } \\
\text { Publications/Pages/default.aspx }\end{array}$ \\
\hline & $\begin{array}{l}\text { Ecosystem Services and } \\
\text { Poverty Alleviation }\end{array}$ & http://www.espa.ac.uk/ \\
\hline & Valuing the Arc & $\begin{array}{l}\text { https://eprints.soton.ac.uk/372347/1/ } \\
\text { VtAspecialissue.pdf }\end{array}$ \\
\hline & $\begin{array}{l}\text { The Mountain Partnership of } \\
\text { the UN FAO }\end{array}$ & $\begin{array}{l}\text { http://www.fao.org/mountain- } \\
\text { partnership/publications/en/ }\end{array}$ \\
\hline & Natural Capital Project & $\begin{array}{l}\underline{\text { https://naturalcapitalproject.stanford. }} \\
\text { edu/publications }\end{array}$ \\
\hline & $\begin{array}{l}\text { Mountain Sentinels } \\
\text { Collaborative Network }\end{array}$ & https://mountainsentinels.org/ \\
\hline
\end{tabular}

Researchers and experts compiled search terms related to components of the research question (Appendix 2). We tested 40 strings of alternative search terms in Web of Science ${ }^{\mathrm{TM}}$ to determine the most comprehensive search. We then built a test 
Fig. 1. Overview of article screening and inclusion in the systematic review (adapted from PRISMA; Moher et al. 2009). EURAC: European Academy of Bozen/Bolzano; Int.: International; AGRICOLA: U.S. Department of Agriculture, National Agricultural Library; UNEP: United Nations Environment Programme; UN FAO: United Nations Food and Agricultural Organization; ICIMOD: International Centre for Integrated Mountain Development; SES: Social-Ecological Systems; Pov.: Poverty; CIPRA: International Commission for the Protection of the Alps.

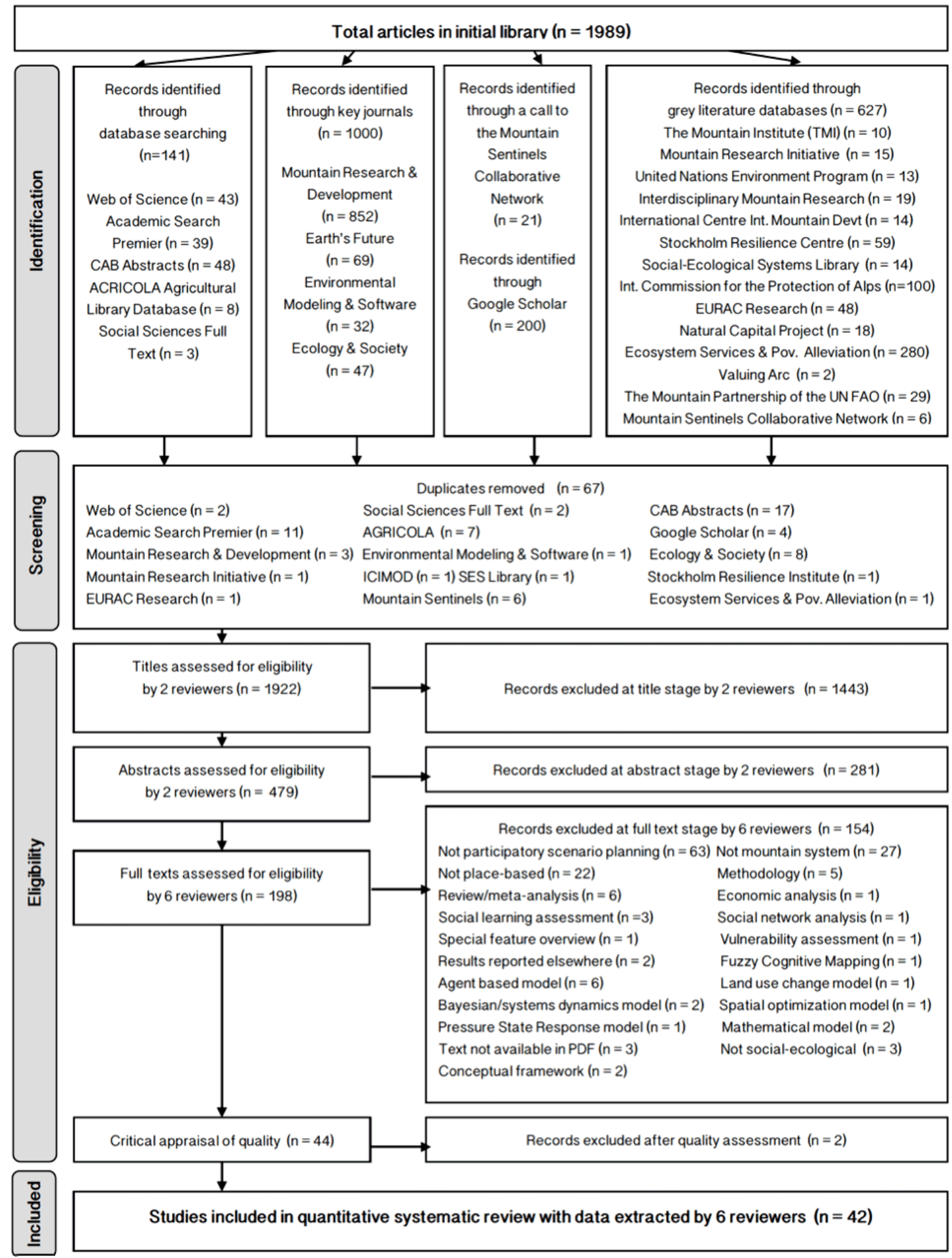


library of 30 references to confirm that the search strings captured relevant literature, balancing specificity and sensitivity (Pullin et al. 2013; Appendix 3, 4). The final string that resulted in 43 relevant studies when tested in Web of Science consisted of the terms: "scenario analy*," "scenario develop*," "scenario plan*," "scenario," "mountain*," "participat*," "collaborat*." These terms were applied to all databases, subject to their individual search requirements. Boolean operator terms and wildcards, i.e., a character that can be used to substitute for other character(s) in a string, connected search terms, which were disaggregated using truncation ("** in most databases). The final searches produced a total of 1989 studies for further screening.

Study inclusion criteria

Studies were included in the review if they do the following: report data on PSP with local stakeholders; include stakeholders living permanently/seasonally in MtSES, or stakeholders affected upstream/downstream, e.g., by ecosystem service provisioning or migration; address interactions of social and ecological systems (van Notten et al. 2003, Binder et al. 2013), or adaptive management (Holling and Allen 2002, Walker et al. 2002, Folke 2007); use qualitative or quantitative data, or both; are available in electronic format; are published in English, given the linguistic competency of the review team; and defined their system of focus to include MtSES facing single- and multiscalar, multisectoral challenges. All publications were included that were published up to November 2017. Of the papers that met the inclusion criteria, only three studies were excluded from the analysis because they were published in other languages, i.e., German, French, and Spanish.

\section{Data screening and critical appraisal}

Six reviewers conducted screening at title, abstract, and full text stages to assess whether studies met the inclusion criteria listed above and chronicled the reason for exclusion in a master Microsoft Excel database (Fig. 1, Appendix 5). At title and abstract screening, Randolph's free-marginal Kappa coefficient, i.e., degree of chance-adjusted agreement, on a random subset of 100 studies was 0.72 , which falls above the normal agreement range of $>0.6-0.7$ (Randolph 2008), indicating that there was sufficient agreement among reviewers. Where there was doubt, we retained the studies. Ambiguities were discussed in regular meetings, and secondary reviewers verified decisions. We used five quality criteria to assess whether studies were of sufficient quality for inclusion (Fig. 2; see Rodríguez et al. 2016).

The development of a nine-step process to guide data coding, extraction, and evaluation

Forty-two studies met the inclusion and quality criteria. We created a codebook (Appendix 6) that was developed and tested on six case studies by two independent investigators. To help structure our coding (and thus, exploration) of the studies, we used themes taken from a synthesis of key issues for MtSES sustainability (Klein et al. 2019b), the global planetary and social boundaries frameworks (Rockström et al. 2009, Raworth 2012), and a nine-step process for conducting PSP that we developed based on a literature review and expert contribution. The ninestep process consisted of methods that were commonly applied in PSP tools and typologies broadly (both within and beyond MtSES), depending on study context, purpose, and goals (e.g., Scholtz and Tietje 2002, van Notten et al. 2003, Oteros-Rozas et al. 2015; Fig. 3). Based on these nine steps, we developed 89 questions that we used to evaluate the extent to which the 42 studies included information about each step. In our evaluation of each study, we also included several open-ended questions pertaining to the primary livelihoods mentioned in each case study, and any strengths and weaknesses of the PSP process. Rather than using a set of pre-existing, theoretically informed codes for these open-ended questions we developed codes inductively. Finally, we used a Likert scale to assess the degree to which each study explicitly addressed uncertainty. Six reviewers evaluated the studies (between 9 November 2017 and 2 February 2018). Each reviewer met with a second reviewer on a weekly basis to discuss and resolve inconsistencies in their coding. See Appendices 7 and 8 for a full list of the case studies analyzed.

Fig. 2. Five criteria used in quantitative quality assessment. Each study that met the inclusion criteria $(n=44)$ received a total quality assessment score of $0-5$, based on the sum of its scores for each quality criterion (yes $=1$, no $=0$ ). Only studies with total scores of 3-5 were considered eligible for further data extraction.

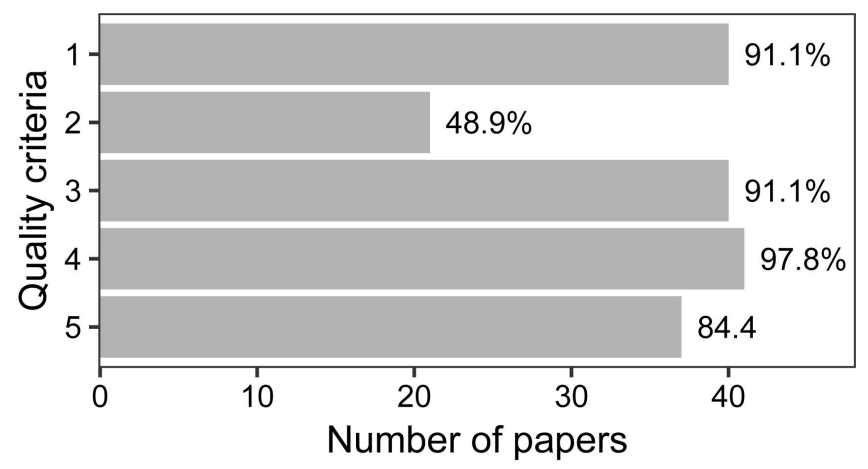

Quality criteria:

1 - Data collection methods are thoroughly explained, clear, replicable

2 - Sample size is well explained and representative of the population

3 - Qualitative or quantitative analytical methods are thoroughly explained, clear, replicable; key terms are well defined

4 - Results/conclusions are logically derived and supported by presented evidence

5 - Confounding factors are considered and well explained

\section{Analysis}

We generated summary statistics based on the frequency of citations and conducted qualitative and quantitative syntheses on trends. We mapped case studies in ESRI ArcGIS 10.5 (ESRI 2015). Point locations of case studies were identified either directly from the reviewed manuscripts, by contacting study authors, or estimated using other geographical information provided in the text. We assessed their geographic distribution relative to the distribution of mountain areas and human populations in MtSES. We defined geographic regions following the United Nations Statistics Division's Intermediate Regions. We calculated mountain areas by region from the $250-\mathrm{m}$ resolution K3 mountain definition (Karagulle et al. 2017; Box 1) and mountain population using the 30-arc-second LandScan ${ }^{\mathrm{TM}} 2017$ dataset (LandScan 2017 ${ }^{\mathrm{TM}}$, ORNL, UT-Battelle, LLC; Rose et al. 2018). 
Fig. 3. A flow chart of the proportion of studies within the systematic review (shown in dark grey in the pie charts and percentages) that provided information on each step of the nine-step process that we used to analyze participatory scenario planning (PSP) case studies in mountain social-ecological systems (MtSES). Appendix 9 provides additional detail. The process starts by establishing the goal of the PSP and defining the context boundaries. Stakeholders then envision desired and undesired futures, i.e., imagining forward-looking strategies, interventions, or innovations that could inspire transformative change. Following this, the internal and external drivers of change within the defined SES boundaries are identified. Narrative storylines are then constructed, which can be transformed into quantifiable models and tested for consistency and plausibility. Process and results are communicated to relevant stakeholders for dissemination and feedback. The PSP process and outputs are then monitored and evaluated to inform future iterations, policy and management priorities, and research.

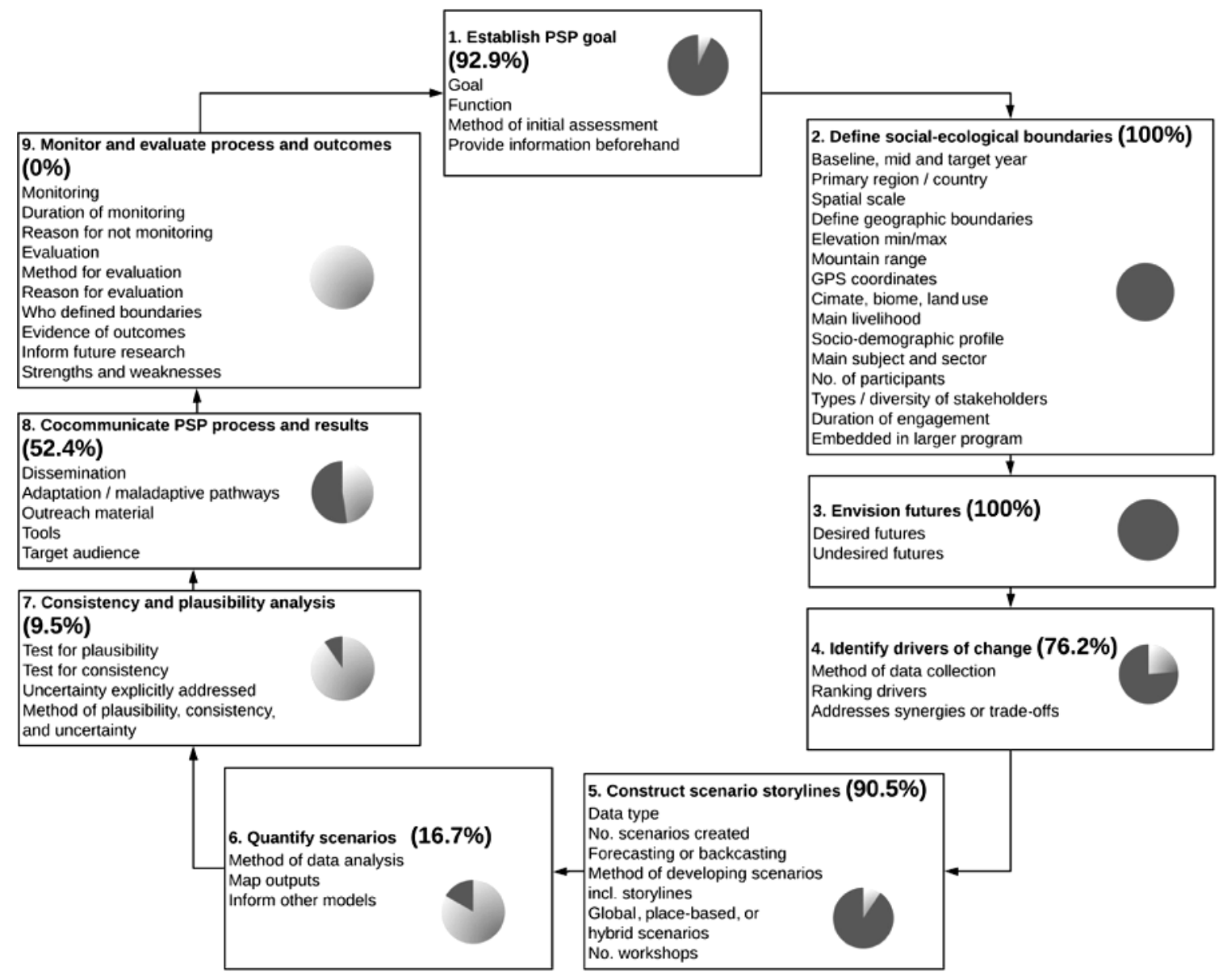

\section{RESULTS}

\section{The state of PSP in MtSES}

\section{Bibliographic patterns}

Empirical research on PSP in MtSES is growing. The first study on the topic was published in 2006 (Fig. 4). Most studies were peer-reviewed articles $(95.2 \%, \mathrm{n}=40)$, published in a wide range of journals $(n=22)$. The remaining two were an unpublished manuscript and a report. Seventeen of the 40 journal articles were open access $(42.5 \%)$. The journals that dominate the literature on this topic are Ecology and Society $(23.8 \%, \mathrm{n}=10)$, followed by Land Use Policy and Mountain Research and Development (9.5\%, $\mathrm{n}=4$ in each). Both Ecology and Society and Mountain Research and Development are fully open access journals. Half (50\%) of the
MtSES PSP studies were coauthored by researchers who had collaborated on other papers included in the review.

\section{Geographic application}

Case studies meeting the inclusion criteria were spread across 39 countries and five continents (Fig. 5). PSP in MtSES has primarily been applied in Europe (54.8\%, $\mathrm{n}=23$ studies). Eight studies were conducted in Asia (19.1\%), half of which were in China; five in Africa $(11.9 \%)$, four of which were in Tanzania; four in North America (9.5\% ea.), all in the United States; and two in Oceania (4.8\%), both in the Australian Alps. Almost half of the PSP studies $(45.2 \%, \mathrm{n}=19)$ were defined by political or administrative units, while $28.6 \%(\mathrm{n}=12)$ were defined by natural features and $21.4 \%(n=9)$ were defined by both. One-third of studies $(n=14)$ were developed at the landscape scale. In terms of the spatial scale, 
six studies were conducted at the farm or village/community level $(14.3 \%)$, four at district level $(9.5 \%)$, nine at regional level $(21.4 \%)$, four at national level $(9.5 \%)$, and five at the international level (11.9\%). Although many MtSES ranges span international political borders, e.g., Mount Elgon, Rwenzori, the Pyrenees, Alps, and Himalayas (Körner and Ohsawa 2006), only five studies researched transboundary MtSES in Asia $(n=2)$ and Europe $(n$ $=3$ ). Eight studies $(19.1 \%)$ explicitly used a spatially nested, multilevel approach.

Fig. 4. Growth in the number of studies on participatory scenario planning (PSP) in mountain social-ecological systems (MtSES) published each year over a 12-year period, $43 \%$ of which were produced between 2015 and 2017. Growth of PSP in MtSES (black) is commensurate to the growth of publications that report on scenarios, both within the field of environmental science $(* 1000$, dark grey) and in all fields $(* 10,000$, light grey), as indicated in a Web of Science search over the same period.

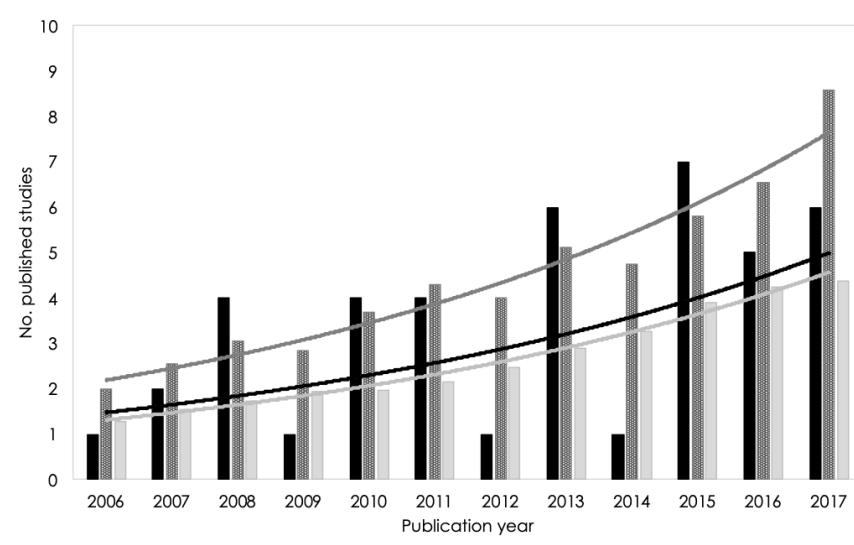

Many of the studies conducted PSP at multiple sites within continents ( $\mathrm{n}=127$ sites). When considering this finer spatial resolution, European sites emerge as particularly overrepresented in the literature $(63.8 \%)$ relative to both the proportion of global mountain area contained in Europe $(17.9 \%)$ and the proportion of the global mountain population inhabiting European MtSES (8.0\%; Fig. 6). East Africa is also overrepresented $(13.4 \%)$ relative to its proportion of mountain area $(5.8 \%)$, but less so when considering its share of the global mountain population $(9.6 \%)$. No sites were located in mountain regions of Northern, Central, and Western Africa, Central and Western Asia, or Central and South America, despite South America containing a relatively high proportion of the global mountain area (12.3\%) and population (7.7\%). North America is also under-represented relative to its proportion of mountain area $(13.1 \%)$, although its share of the global mountain population is low $(2.2 \%)$. East Asia is most severely under-represented (3.9\%), considering that it contains the largest proportion of mountain area $(17.3 \%)$ and highest population of any region $(29.6 \%)$.

\section{Temporal scope}

The mean time span between the scenario creation and the projected year was 33 years, but scenarios ranged from 14 to 90 years into the future. The mean baseline year for scenarios was 2009, ranging from 2000 to 2015, while the mean target year for scenarios was 2042, ranging from 2020 to 2100. Thirty-eight studies $(90.5 \%)$ used a single target year. Only eight studies $(19 \%)$ used a midterm horizon year to mark incremental progress toward final scenarios, with a mean of 2023, ranging from 2010 to 2040.

Fig. 5. Map of study locations. The inset map depicts the European region. Some of the study areas indicated with black dots closely overlap. The blue shaded areas represent mountains, as defined by Karagulle et al. (2017). Definitions of mountains by the authors of the studies included in this review may differ.

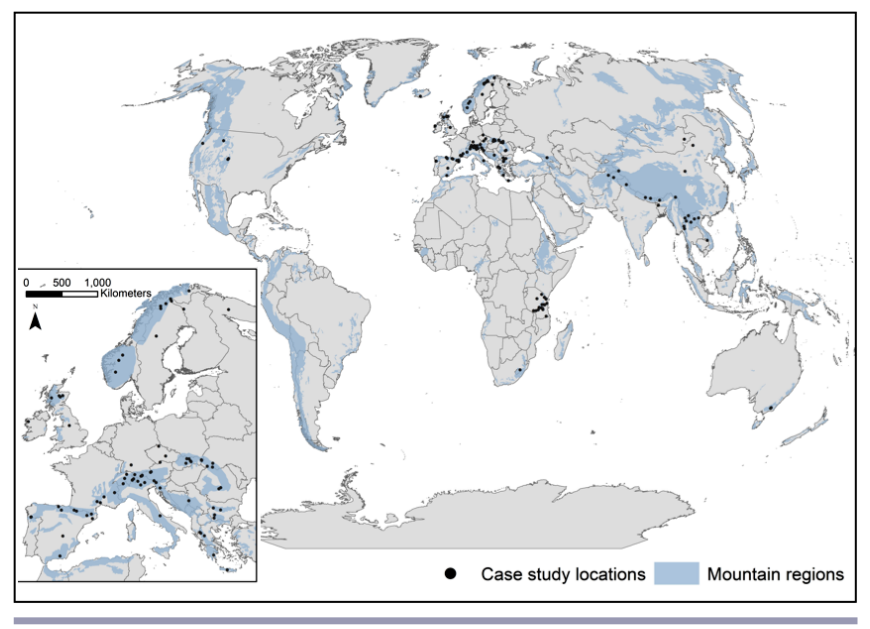

Thematic coverage

The most prominent themes identified through PSP in MtSES were governance and policy change, which were addressed in all studies $(100 \%, \mathrm{n}=42)$; land use change and its economic drivers, e.g., markets, income, and employment $(92.9 \%, \mathrm{n}=39)$; the maintenance of cultural or biological diversity $(81 \%, n=34)$ and, conversely, biodiversity loss $(78.6 \%, \mathrm{n}=33)$; demographic change $(78.6 \%, \mathrm{n}=33)$; technological/infrastructure change $(71.4 \%, \mathrm{n}=$ $30)$, and climate change $(66.7 \%, \mathrm{n}=28$; Fig. 7). Aside from technological/infrastructure change, all of these topics were identified as key issues in MtSES by Klein et al. (2019b). Several of the "planetary boundaries" (Rockström et al. 2009), including land use change $(92.9 \%)$, biodiversity loss $(78.6 \%)$, climate change $(66.7 \%)$, and freshwater use $(64.3 \%)$, were frequently the focus of studies. Of these planetary boundaries, chemical pollution $(14.3 \%)$ and phosphorus or nitrogen cycles $(4.8 \%$ ea.) received less attention, while stratospheric ozone depletion, ocean acidification, and atmospheric aerosol loading were not addressed in any of studies. From Raworth's (2012) "environmentally safe and socially just space for humanity" framework, income and jobs (92.9\%), water (64.3\%), food $(47.6 \%)$, education $(45.3 \%)$, and energy $(42.9 \%)$ were frequently addressed, while other key aspects, such as social equity and voice $(26.2 \%)$, health $(23.8 \%)$, gender equality $(4.8 \%)$, and sanitation $(0 \%)$, were infrequently addressed.

\section{The nine-step PSP process}

We explored the extent to which studies employed each step in the nine-step PSP process (Figs. 3 and 7), as described below. We found $50 \%$ of the studies addressed at least eight of the nine steps outlined. 
Fig. 6. The distribution of participatory scenario planning (PSP) study sites differs among geographic regions. The percentage of PSP study sites in each region (relative to all PSP study sites) is compared to the percentage of mountain area located in each region (relative to the total global mountain area; (a) and to the percentage of people living in mountains in each region (relative to the total global mountain population; (b). In (a, b), points with numeric labels are coded as follows: $1=$ Western Africa, $2=$ Central Asia, $3=$ Northern Africa, $4=$ Central Africa, $5=$ Western Asia, $6=$ Caribbean and Central America. Dashed lines represent a 1:1 relationship. Population density in mountains varies across geographic regions (c). Geographic regions are drawn from the United Nations' definition of Intermediate Regions (d).
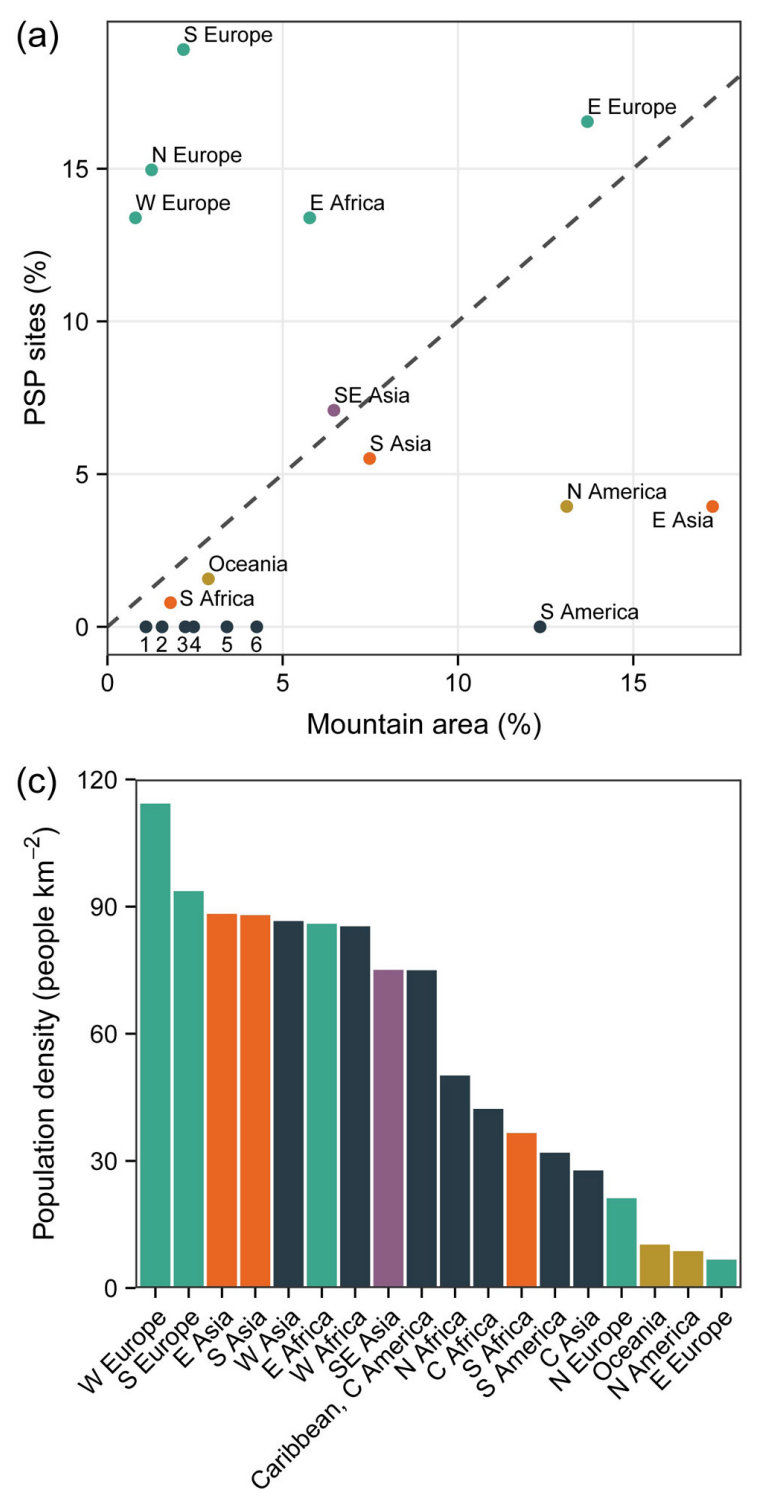

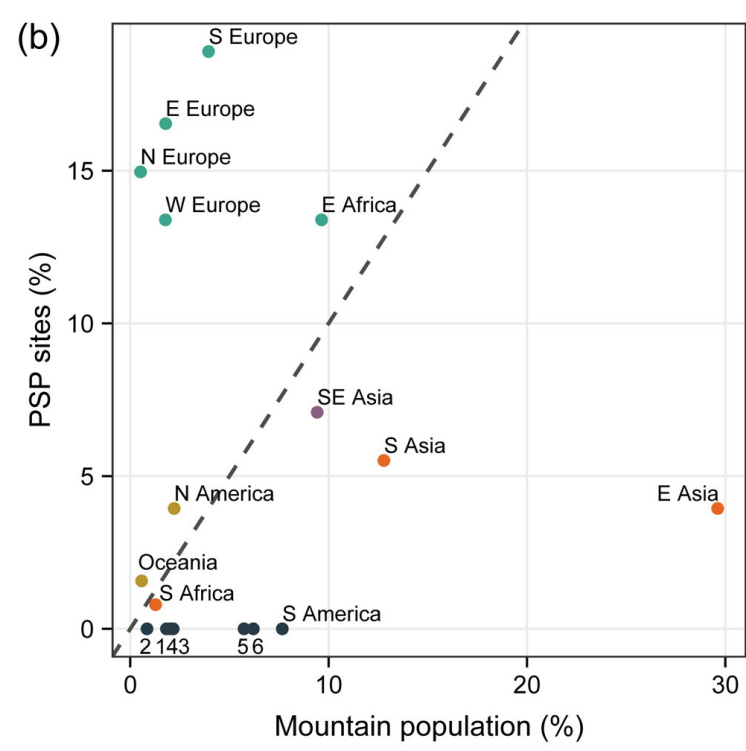

(d)

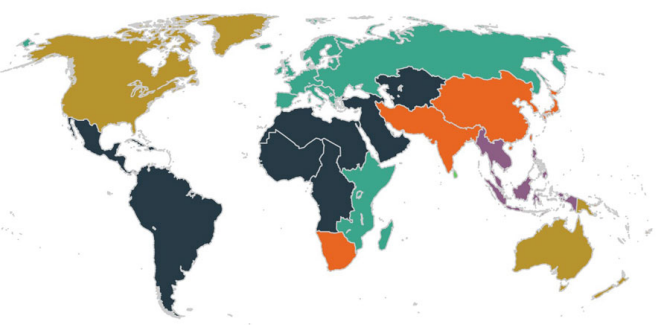

Overrepresented relative to area and population

Underrepresented relative to area

Underrepresented relative to population

Underrepresented relative to area and population

Not represented

\section{Step 1. Establish PSP goal}

Most studies $(97.6 \%, \mathrm{n}=41)$ stated a clear PSP goal at the beginning of their project. The most common goal (or purpose) was to improve understanding among stakeholders $(78.6 \%, \mathrm{n}=$ 33 ), by explicitly integrating their diverse views into shared representations of the future. Decision support was the goal of $45.2 \%(n=19)$ of studies, often focusing on ecosystem service management, REDD+ initiatives, climate change mitigation to reduce greenhouse gas emissions, or national planning. The next most frequently stated goal of PSP was for prediction $(31.0 \%, \mathrm{n}$ $=13)$, followed by learning $(11.9 \%, \mathrm{n}=5)$ and communication $(9.5 \%, n=4)$. Building on categories created by van Notten et al. (2003), we determined that the goal of PSP was exploratory (i.e., creating scenarios to examine plausible drivers of change) in $61.9 \%$ of studies $(n=26)$, prepolicy (i.e., creating scenarios to examine futures according to their desirability) in $23.8 \%$ of studies $(\mathrm{n}=10)$, and both exploratory and prepolicy in $14.3 \%$ of studies $(n=6)$. 
Fig. 7. The percentage of studies that employed each step of the nine-step process for participatory scenario planning (PSP) in mountain social-ecological systems (MtSES). The themes (2a-d) are defined when determining boundary conditions. These form the main focus of alternative futures explored in the scenarios. Step 2a comes from Rockström et al. 2009, Step 2b from Raworth 2012, and Step 2c and 2d from Klein et al. $2019 b$ (see Appendix 9 for further details). NTFP = nontimber forest products.
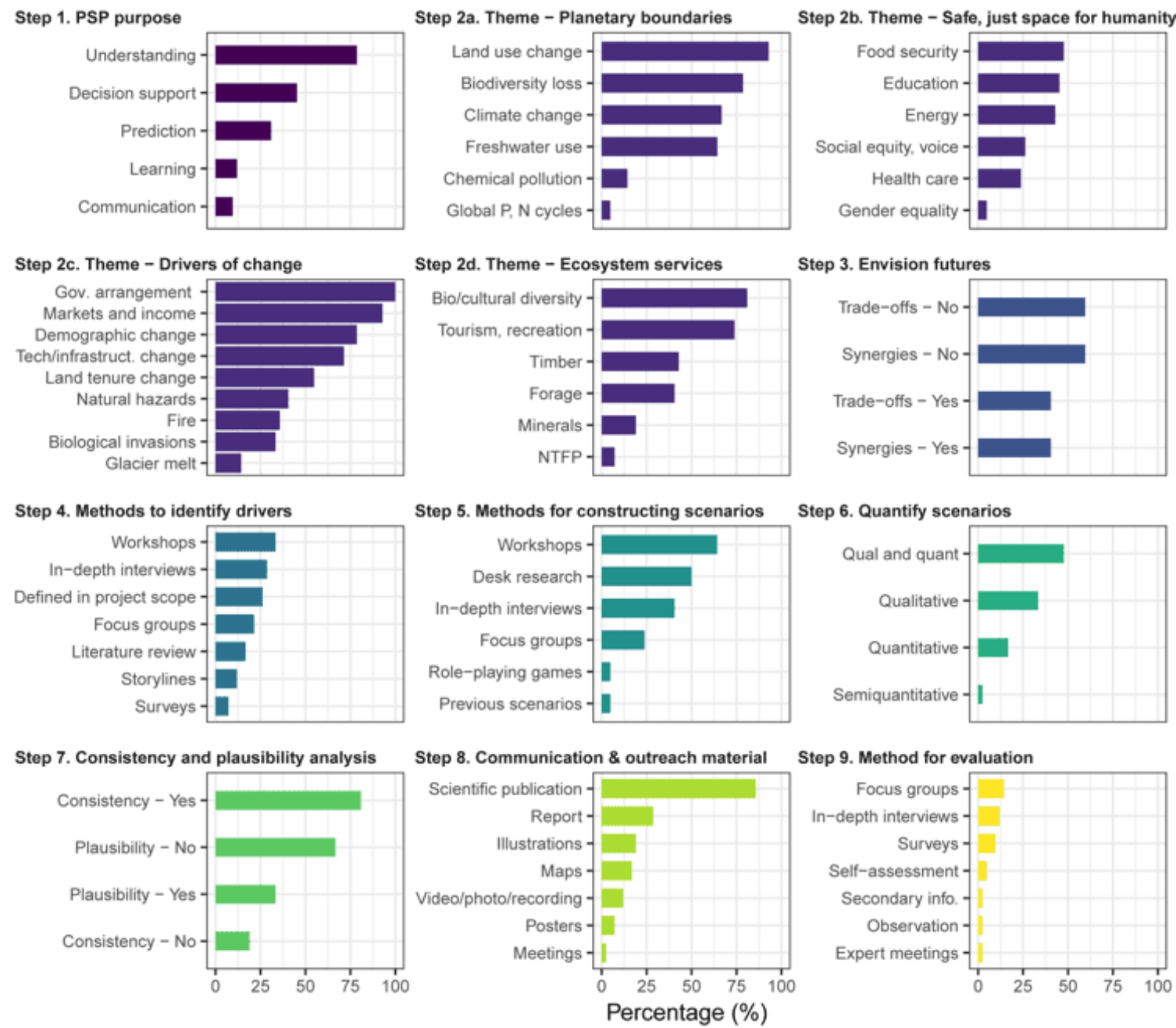

Overall, studies' functions were more process oriented $(\mathrm{n}=20$, $47.6 \%)$ than product oriented $(\mathrm{n}=9,21.4 \%)$, indicating that tangible outcomes were less frequently reported. In most studies $(92.9 \%, n=39)$, initial assessments were conducted to obtain background information, often by building on long-term research collaborations $(42.9 \%, \mathrm{n}=18)$, key stakeholder open/closedended interviews and informal consultations $(40.5 \%, \mathrm{n}=17)$, or a literature review $(19 \%, n=8)$. In $42.9 \%(n=18)$ of studies, participants were given information about trends, history, and the PSP process beforehand, while $52.4 \%(n=22)$ of studies did not report this.

Step 2. Define social-ecological system boundaries

All studies defined the system boundaries prior to developing scenarios. These boundaries entail multiple aspects, such as the climate, biomes, land use, and livelihoods of the MtSES and features of the PSP process, such as the thematic focus, number or diversity of stakeholders involved, and the length of their involvement. Recognizing that these categories are nonexclusive, we find that most studies were defined by issues $(73.8 \%, \mathrm{n}=31)$, more so than by geographic areas $(14.3 \%, n=6)$ or the types of stakeholders or institutions involved $(7.1 \%, \mathrm{n}=3)$.

The majority of studies $(52.4 \%, \mathrm{n}=22)$ were located in temperate regions, one-fifth in dryland or semiarid $(19.1 \%, \mathrm{n}=8), 16.7 \%(\mathrm{n}$ $=7)$ in tropical or subtropical, and $11.9 \%(n=5)$ in alpine, inneralpine, cold continental, or subarctic regions. Six studies $(14.3 \%)$ spanned multiple climatic zones. Studies were primarily situated in forested biomes $(59.5 \%, \mathrm{n}=25)$, in either protected $(33.3 \%, \mathrm{n}$ $=14$ ) or unprotected areas $(26.2 \%, \mathrm{n}=11)$, closely followed by grasslands, shrublands, or savannahs $(50 \%, \mathrm{n}=21)$. Few scenario studies were located in urban or peri-urban areas $(11.9 \%, \mathrm{n}=5)$ 
or tundra $(7.1 \%, n=3)$. Nearly a third of studies $(n=12)$ spanned multiple biomes.

Tourism and recreation comprised the largest proportion of land uses studied $(50 \%, \mathrm{n}=21)$, followed by agro-pastoralism $(42.9 \%$, $\mathrm{n}=18)$ and timber/logging $(33.3 \%, \mathrm{n}=14)$. Few residential areas $(9.5 \%, \mathrm{n}=4)$ have been studied using PSP. Over a quarter of studies $(28.6 \%, \mathrm{n}=12)$ focused on one land use, while $50 \%$ studied two $(n=21), 11.9 \%$ studied three $(n=5)$, and $9.5 \%$ studied four $(\mathrm{n}=4)$. The primary local livelihood was smallholder or commercial agriculture $(57.1 \%, \mathrm{n}=24)$. Other important livelihoods were trade and tourism $(54.8 \%, \mathrm{n}=23)$, and private industry, e.g., mining, hunting, and forestry $(50 \%, \mathrm{n}=21)$. Most studies $(81 \%, n=34)$ stated the socio-demographic profile of the participants.

The most prominent stakeholders participating in the processes were district, regional, and national government officials $(57.1 \%$, $\mathrm{n}=24)$, land managers $(52.3 \%, \mathrm{n}=22)$, and conservation groups, park authorities, and NGOs $(47.6 \%, \mathrm{n}=20)$. Municipal institutions, community councils, or tribal and indigenous organizations were only represented in a third of cases $(33.3 \%, \mathrm{n}$ $=14)$, followed closely by private $(31 \%, \mathrm{n}=13)$ and academic $(21.4 \%, \mathrm{n}=9)$ institutions. No studies included bilateral or multilateral organizations. The number of participants ranged from 11 to 240 individuals, averaging $48.4 \pm 9.9$ (mean \pm SE). PSP studies most frequently had three different types of stakeholder groups participating in workshops $(23.8 \%, \mathrm{n}=10)$, although this ranged from 1 to 10 . Few included more than six types of stakeholders $(9.5 \%, \mathrm{n}=4)$. Stakeholder engagement typically lasted one year $(47.6 \%, n=20)$, followed by $1-4$ years $(23.8 \%, n$ $=10$ ). Only one study indicated long-term ( $>10$ years) engagement with stakeholders in the process. The PSP process was described as embedded in a larger research program in $40.5 \%$ $(n=17)$ of cases. (See "Thematic coverage" above and Fig. 7 for additional details on the use of themes.)

Step 3. Envision desiredlundesired futures

All reviewed MtSES PSP studies included envisioned desired and undesired futures. Less than half of the studies discussed synergies and trade-offs $(40.5 \%, \mathrm{n}=17)$ between desired and undesired futures.

\section{Step 4. Identify drivers of change}

The majority $(76.2 \%, \mathrm{n}=32)$ of studies identified drivers of change, using a range of methods such as participatory workshops $(33.3 \%, \mathrm{n}=14)$, in-depth interviews $(28.6 \%, \mathrm{n}=12)$, project scoping $(26.2 \%, \mathrm{n}=11)$, and focus group discussions $(21.4 \%, \mathrm{n}=9)$. Most studies $(61.9 \%, \mathrm{n}=26)$ did not rank drivers in terms of importance or threat to the system.

\section{Step 5. Construct scenario storylines}

Most scenarios included storylines or narratives, i.e., qualitative description of future developments $(90.5 \%, \mathrm{n}=38)$. Scenarios were normally constructed using forecasting $(90.5 \%, \mathrm{n}=38)$ rather than backcasting $(4.8 \%, \mathrm{n}=2)$, while two studies used both $(4.8 \%)$. Data were typically collected from workshops $(64.3 \%, \mathrm{n}$ $=27)$, desk-based research $(50 \%, \mathrm{n}=21)$, interviews $(40.5 \%, \mathrm{n}=$ $17)$, and focus group discussions $(23.8 \%, \mathrm{n}=10)$. Twenty-six studies used a combination of two to four of these methods to construct the scenarios, whereas only two studies used a single method. On average, two to three workshops were held over the
PSP process (ranging from zero to eight). Over half used only local-level scenarios $(57.1 \%, \mathrm{n}=24)$, while fewer used only regional/global scenarios $(11.9 \%, \mathrm{n}=5)$, and about one-third of studies used a hybrid of local and regional/global scenarios $(31 \%$, $\mathrm{n}=13)$.

\section{Step 6. Quantify scenarios}

Almost half of studies $(47.6 \%, \mathrm{n}=20)$ combined qualitative and quantitative scenarios, while only $16.7 \%$ studies $(n=7)$ used purely quantifiable scenarios, i.e., built models of change using indicators that can be measured, based on expert elicitation or extrapolating past trends. One-third of the studies used only qualitative scenarios $(33.3 \%, \mathrm{n}=14)$, i.e., using "what-if" narrative storylines, and one study (2.4\%) was semiquantitative. Scenarios were predominantly qualitatively analyzed using cluster analysis of heterogeneous rank data and impact analysis $(40.5 \%, \mathrm{n}=17)$ and participant surveys $(28.6 \%, \mathrm{n}=12)$. Geographic Information Systems were used to model dynamic relationships over time and space in $26.2 \%$ of studies $(n=11)$. Slightly less than half of studies $(45.3 \%, \mathrm{n}=19)$ used PSP to inform other models, including agent-based $(16.7 \%, \mathrm{n}=7)$, land use change $(11.9 \%, \mathrm{n}=5)$, debris flow $(9.5 \%, \mathrm{n}=4)$, mass balance, hydrological, Bayesian networks, or dynamic models $(7.1 \%, \mathrm{n}=$ 3 ea.).

Step 7. Consistency and plausibility analysis

Only $9.5 \%$ of studies employed both consistency and plausibility analyses $(n=4)$. Very few $(19 \%, n=8)$ conducted a test for consistency, whether internal, i.e., reviewing whether impact variables within a narrative can occur in combination, or external, i.e., whether diverse future states, or local/global scenarios contradict one another. One-third of studies $(33.3 \%, n=14)$ conducted a test for plausibility, i.e., if the scenario falls within the limits of what might conceivably happen. Methods included historical or expert validation, comparing findings to published results from neighboring areas and/or other models, and assessing policies, plans, and actions to identify barriers and bridges to desired outcomes.

Although divergent futures implicitly capture uncertainty, only in 18 cases did the six reviewers strongly agree $(7.1 \%, n=3)$ or agree $(35.7 \%, \mathrm{n}=15)$ that studies explicitly addressed uncertainty. Three main methods were used in the studies to address uncertainty: positioning scenarios along two axes representing extremes (e.g., high/low), ranking scenarios using a scale, or discussing limitations and data resolution. No studies measured stakeholders' degree of confidence in the data inputs or outputs.

\section{Step 8. Cocommunication of PSP process and results}

Dissemination of results to stakeholders involved in the PSP process was mentioned in half the studies $(50 \%, \mathrm{n}=21)$. Dissemination aimed to summarize findings, ensure results are understood, obtain feedback, and discuss intentions to apply the evidence to real-world challenges. In most cases, the target audiences were participants who developed the scenarios $(45.2 \%$, $\mathrm{n}=19)$ or researchers $(42.9 \%, \mathrm{n}=18)$. Occasionally, intended audiences were decision makers operating at sub/national levels. To communicate results beyond the group involved in the PSP process, the main outreach materials were scientific publications $(85.7 \%, \mathrm{n}=36)$ and reports $(28.6 \%, \mathrm{n}=12)$. The main tools were knowledge representation or cognitive conceptualization diagrams, which represent system entity, processes, and 
interactions $(35.7 \%, \mathrm{n}=15)$, spatial representation tools $(33.3 \%$, $\mathrm{n}=14)$, narratives $(16.7 \%, \mathrm{n}=7)$, or other simulation tools $(16.7 \%$, $\mathrm{n}=7$ ). Often a combination of tools, such as maps, diagrams, and three-dimensional landscape visualizations, was used to help different audiences, such as local inhabitants and authorities, to conceptualize models $(40.5 \%, \mathrm{n}=17)$.

Step 9. Monitor and evaluate process and outcomes

No studies conducted both monitoring and evaluation. One study monitored outcomes over one year using systematic data collection to track progress using indicators (Bogdan et al. 2016). Most studies $(66.7 \%, \mathrm{n}=28)$ did not formally evaluate the design, implementation, results, or consequences of social learning. Half of all studies included in the review $(\mathrm{n}=21)$ provided evidence of short- and long-term outcomes, while few $(7.1 \%, n=3)$ used outputs to inform further research. Evaluation methods included qualitative, self-reflexive assessments in focus groups, interviews, surveys, literature reviews, participant observation, and expert meetings. Table 2 summarizes the strengths and weaknesses of the PSP process reported by participants.

\section{DISCUSSION}

Our evaluation of how PSP has been employed in MtSES, including a characterization of the process, is organized around the following key areas. First, we evaluate the geographic, temporal, and thematic foci of the studies. We then examine the benefits of PSP for MtSES using the nine-step PSP process, explicitly considering the goals of the process (Step 1), the stakeholders/institutions involved and how the boundaries of the MtSES were defined (Step 2), the identification of drivers of change (Step 4), the cocommunication of the PSP process and results (Step 8), and the evaluation of process and outcomes (Step 9). Steps 3 and 5 are examined in detail in a subsequent paper. Finally, to identify key gaps in PSP for MtSES, and what can be learned from the application of PSP in other SES, we analyze which steps in the nine-step process were frequently omitted.

\section{How has PSP been employed in MtSES, with what geographic, temporal, and thematic foci?}

\section{Geographic application}

Although MtSES research is on the rise (Gleeson et al. 2016), the geographic coverage of PSP in MtSES remains biased toward European countries, with less focus in Asian, African, and Latin American MtSES, relative to their total extent and total human population. Globally, population density is highest in Western and Southern European MtSES (Fig. 5), where 32.3\% of PSP sites are located. By contrast, East Asian MtSES cover the largest area and host the highest total human population of any MtSES globally, but only $3.9 \%$ of PSP sites are located there. South America has a relatively large share of mountain area $(12.3 \%)$, but completely lacks PSP studies. Although these results may be an artefact of our language selection criteria, we consulted with MtSES experts working in these regions, who confirmed that to their knowledge no published records of PSP exist to date (although other methods to assess SES may have been applied). This finding reflects similar biases in broader conservation research, where comparatively less research is undertaken in the world's most biodiverse countries (Meijaard et al. 2015), and the science conducted is often not led by researchers based in-country (Boakes et al. 2010, Thorn et al. 2016, Wilson et al. 2016).
A lack of MtSES PSP application in developing countries may bias any synthesis effort toward the values, needs, and context of regions where it is more frequently conducted, i.e., Europe, with the risk that these conclusions may then be translated incorrectly to other regions (Hovland 2003). Therefore, commonalities and divergences in trajectories of change across MtSES should be analyzed by taking into account SES across an array of socioeconomic-cultural conditions. Efforts to synthesize across global MtSES must remain cognizant of these biases, and work to mitigate them. For example, the MtSES research community needs to closely consider ways to address the entrenched disadvantages some countries have when initiating research projects, e.g., access to funding, in-house research support offices, language (Meijaard et al. 2015). There is also a need to reduce the logistical and financial burden of studying across international political borders. In particular, regional organizations have a key role to play in enhancing transboundary cooperation, as evidenced by the PSP work in the Hindu Kush Himalaya by the International Centre for Integrated Mountain Development (Roy et al. 2019).

Although it has been suggested that MtSES are best analyzed across scales, where material and social connections between the highlands and lowlands become clear (Jaeger et al. 2017), our review revealed few scenarios with this type of nested, multilevel approach. This is not surprising because multilevel analyses are more complicated and require a greater diversity of actors and resources. The spatial scale selected could reflect the priorities of actors responsible for managing adaptation pathways or of institutions driving the PSP process. More multiscale spatial and organizational integration is therefore required across the different phases of PSP to improve the extent to which different MtSES perspectives are incorporated (Lebel 2006, Biggs et al. 2007, Brand et al. 2013, Mistry et al. 2014, Rosa et al. 2017).

\section{Temporal scope}

There has been a steady increase in studies concerning MtSES since 2006, perhaps mirroring the growth in international global climate and biodiversity assessments that have increasingly referenced PSP research, e.g., Global Biodiversity Outlook and subglobal Millennium Ecosystem Assessment scenarios. For instance, spikes in 2013 and 2015 occurred when planning processes increasingly adopted PSP to envision future pathways and social science methods, e.g., International Panel on Climate Change (IPCC) Fourth Assessment or Sustainable Development Summit, and when the International Panel on Biodiversity and Ecosystem Services (IPBES) was launched. These trends indicate a growing interest in MtSES futures, both locally and meeting large-scale sustainability challenges, whilst demonstrating increased investment in MtSES research.

The temporal scope of PSP in MtSES is wide ranging. Many studies selected medium-term time horizons ( $\sim 30$ years), which may be associated with forecasts of human population or species distributions, successional change in forests, the generational memory of land managers, infrastructural lock-in, or multidecadal climate change projections. Near-term horizons of 14 years, the shortest of any study in this review, may be associated with municipal planning or business cycles, institutional memory, or international strategies such as the Sustainable Development Goals. The longest time horizon of scenarios was 90 years, 
Table 2. Strengths and weaknesses reported by stakeholders participating in the studies, showing that there are clear benefits to participatory scenario planning (PSP), e.g., consensus building and dialogue, illuminating assumptions and interconnections, but also limits to the process and use of PSP, e.g., extent of representativeness for concrete decision making, knowledge- and resource-intensive. SES = social-ecological system.

\begin{tabular}{|c|c|c|}
\hline Strengths and weaknesses & Explanation & Examples of references \\
\hline \multicolumn{3}{|l|}{ Strengths } \\
\hline Bring together stakeholders views & $\begin{array}{l}\text { Joint problem definition, conceptual framing, consensus building } \\
\text { Trans- or cross-disciplinary dialogue across epistemologies, methods, } \\
\text { vocabularies, values, cultures, assumptions, and power differentials } \\
\text { Engage minority groups in decision making }\end{array}$ & $\begin{array}{l}\text { Lamarque et al. } 2013 \text {, } \\
\text { Oteros-Rozas et al. } 2013\end{array}$ \\
\hline Facilitate SES thinking & $\begin{array}{l}\text { Apply to policy, planning, and management } \\
\text { Stimulate creative thinking } \\
\text { Combine scientific and local knowledge }\end{array}$ & $\begin{array}{l}\text { Barnaud et al. } 2007 \text {, } \\
\text { Allington et al. } 2018\end{array}$ \\
\hline Reduce complexity & $\begin{array}{l}\text { Reduce complexity to focus strategic action } \\
\text { Avoid complex models that are difficult to understand }\end{array}$ & $\begin{array}{l}\text { Daconto and Sherpa } 2010 \text {, } \\
\text { Mitchell et al. } 2015\end{array}$ \\
\hline Address uncertainty & $\begin{array}{l}\text { Test adaptive governance attributes to deliver acceptable outcomes } \\
\text { across futures } \\
\text { Recognize path dependency }\end{array}$ & $\begin{array}{l}\text { Mitchell et al. } 2015 \\
\text { Murphy et al. } 2016\end{array}$ \\
\hline Encourage long-term regional development & $\begin{array}{l}\text { Envision and manage trade-offs, e.g., land use, ecosystem services } \\
\text { Improve confidence, negotiation, and adaptability } \\
\text { Develop monitoring framework }\end{array}$ & $\begin{array}{l}\text { Bourgoin and Castella 2011, } \\
\text { Malinga et al. } 2013\end{array}$ \\
\hline Policy recommendations & $\begin{array}{l}\text { Adequate to temporal and spatial specificities } \\
\text { Tool to prepare policy strategies in a continuous, dynamic process }\end{array}$ & $\begin{array}{l}\text { Enfors et al. } 2008 \text {, } \\
\text { Carlsson et al. } 2015\end{array}$ \\
\hline Transferability of models & $\begin{array}{l}\text { Methods embed place-based knowledge into quantitative modeling } \\
\text { Apply to future or larger research }\end{array}$ & $\begin{array}{l}\text { Jaeger et al. } 2017 \text {, } \\
\text { Allington et al. } 2018\end{array}$ \\
\hline \multicolumn{3}{|c|}{ T: } \\
\hline Lack of detail & $\begin{array}{l}\text { Limited clarification of well-defined problem } \\
\text { Limited description of outcomes, or detailed storylines }\end{array}$ & $\begin{array}{l}\text { Walz et al. } 2007 \\
\text { Murphy et al. } 2016\end{array}$ \\
\hline Bias in sampling and facilitation & $\begin{array}{l}\text { Facilitators can impose personal bias if eliciting participation and } \\
\text { collaboration } \\
\text { Typically limited participation from urban areas }\end{array}$ & $\begin{array}{l}\text { Soliva and Hunziker 2009, } \\
\text { Capitani et al. } 2016\end{array}$ \\
\hline Unrealistic & $\begin{array}{l}\text { Without consistency analyses, combinations of scenarios can be } \\
\text { unrealistic } \\
\text { Results are not always representative for concrete decision making }\end{array}$ & $\begin{array}{l}\text { Daconto and Sherpa } 2010 \\
\text { Kohler et al. } 2017\end{array}$ \\
\hline Small sample size & $\begin{array}{l}\text { Typically few participants in workshops } \\
\text { Few of the same stakeholders attend follow-on meetings }\end{array}$ & $\begin{array}{l}\text { Bayfield et al. } 2008, \\
\text { Carlsson et al. } 2015\end{array}$ \\
\hline High expectations of model integration & $\begin{array}{l}\text { Scenarios not well-integrated as SES } \\
\text { Typically few variables are considered } \\
\text { Extrapolation of local results challenging }\end{array}$ & $\begin{array}{l}\text { Malinga et al. 2013, } \\
\text { Loibl and Walz } 2010\end{array}$ \\
\hline Resource intensive & $\begin{array}{l}\text { Time-, financially-, and labor-intensive process } \\
\text { Knowledge is needed to understand all aspects at stake }\end{array}$ & $\begin{array}{l}\text { Bourgoin and Castella 2011, } \\
\text { Kohler et al. } 2017\end{array}$ \\
\hline Lack of implementation & $\begin{array}{l}\text { Lack of robust planning mechanisms, implications rarely explored } \\
\text { Lack of adaptive governance systems with the capacity to implement } \\
\text { scenarios }\end{array}$ & $\begin{array}{l}\text { Carvalho-Ribeiro et al. } 2010 \text {, } \\
\text { Allington et al. } 2018\end{array}$ \\
\hline
\end{tabular}

appropriate to envision structural changes in the 21 st century, such as transitions from subsidized, centralized, and large-scale reliance on fossil fuels to greater energy efficiency, lower energy consumption, and sustainable building designs (Lebel 2006, Walz et al. 2014, Sarkki et al. 2017). Capturing this range of scales is important in MtSES, considering that cycles of resource abundance and scarcity may occur at different repeat intervals, e.g., interannual or decadal drought cycles and intra-annual seasonal variability, and therefore long-term planning and program longevity are needed (Mitchell et al. 2015). Furthermore, exploration of nested temporal scales is needed because people's perceptions of the short-term is often more certain, relevant to current needs, and easy to envision compared to the long term. This is analogous to spatial scales, where connections across smaller landscapes are clearer than connections linking MtSES with lowland SES (Huber et al. 2013), or when telecoupling links distant markets in complex social-hydrological relationships (Chignell and Laituri 2018).

\section{Thematic coverage}

Key themes that emerge as important for the future sustainability of MtSES are governance, economy, land use change, and biodiversity (Fig. 7, Appendix 9). These themes, which we describe below, resonate with those raised in other place-based PSP literature (e.g., Oteros-Rosaz et al. 2015). There are key themes that were not addressed in our review, despite their importance in MtSES literature. Planetary boundaries (Rockström et al. 2009) such as stratospheric ozone depletion and nutrient cycling were not addressed, likely because they lie beyond the immediate concerns of MtSES stakeholders. Two themes from the social boundaries (Raworth 2012) that we would expect to be important in MtSES, gender equality, e.g., women's engagement in upland agricultural markets, and adequate sanitation for all, e.g., open defecation-free status, have also been overlooked (Manfredi et al. 2010, Molden et al. 2014, Budhakoti et al. 2017, Klein et al. $2019 b$ ). Similarly, the repercussions and opportunities of permafrost thaw (Yang et al. 2018, Nyima and Hopping 2019) 
and use and trade of medicinal resources, including high value commodities (Bourgoin and Castella 2011, Hopping et al. 2018), received little attention.

Governance: Our analysis suggests that MtSES would benefit from improved horizontal (across space) and vertical (across levels of organizations) governance, and responsive institutions, alongside improved communication, knowledge coproduction, and cooperation among key actors, especially when there are contested views (Lamarque et al. 2013). Securing the livelihoods of MtSES communities rests on better inclusion of local landowners in decision-making processes and action at the subnational level. Enhancing transboundary cooperation across political borders, particularly in relation to transportation infrastructure, may facilitate domestic and international accessibility to remote MtSES regions and thereby improve market access, infrastructural development, and tourism. Strong social safety nets, effective local leadership, informal networks, and strong national institutions combined with international mechanisms will be needed so that marginal upland communities, who often manage MtSES commons, have secure resource rights (Bourgoin and Castella 2011).

Economy: Our review highlights the need for greater attention to trade-offs and equity in MtSES economic transitions. Scenarios identified the potential decline or replacement of traditional sectors, e.g., pastoral, agricultural, and timber, by industrial and service sectors, e.g., tourism, settlement, and manufacturing (Bayfield et al. 2008, Kohler et al. 2017, Barnaud et al. 2007), which could lead to depopulation, land abandonment, and the loss of traditional practices and cultural heritage in upland areas (Tzanopoulos et al. 2011). Conversely, this could encourage changing patterns of in-migration and reruralization as a result of new employment opportunities, investments in upland areas, lifestyle changes, and new market opportunities for niche products (Zhen et al. 2014). Increased tourism may also significantly benefit communities in MtSES if revenues are used for species conservation and providing public services, but could also lead to cultural knowledge loss and pollution (Mitchell et al. 2015). Emerging opportunities lie in payments for ecosystem service schemes including carbon markets, reforestation, restoration, afforestation, sustainable charcoal production (Malinga et al. 2013), but with shortcomings, such as windfall profits or elite capture. Many scenarios foresee MtSES farmers shifting away from subsistence agriculture to cultivating for recreational purposes, i.e., leisure farming and eco-/agri-tourism (Enfors et al. 2008, Soliva and Hunziker 2009). Improvements in telecommunication, infrastructure, information communication technology, telebanking, and access to remote sensing technology could lead to more off-farm livelihood diversification and specialized market chains (Lebel 2006, Daconto and Sherpa 2010, McBride et al. 2017). However, the extent to which MtSES will benefit from technological innovation is contingent on a wide spectrum of legal, governance, economic, institutional, and environmental factors (Capitani et al. 2016, Roy et al. 2019).

Land use change: In the future, landscape multifunctionality, connectivity, land tenure rights, and spatial planning, including land demarcation and zoning (Malek and Boerboom 2015), will play an increasingly important role for sustainable management of MtSES. Our analysis suggests that changing demographic and migration patterns will cause a shift in land uses and their associated ecosystem services, resulting in new sustainability challenges in MtSES. For example, food insecurity may become an even larger challenge if people move away from traditional agricultural-based production systems toward more industrialized systems (Zhen et al. 2014), calling for more multifunctional landscapes. Investment support from government, private sector, and local associations can improve the future viability of agricultural and pastoral activities in MtSES (Lamarque et al. 2013, Malinga et al. 2013, Wyborn et al. 2015), particularly in areas under threat from imminent land privatization, land scarcity, and climate change (Allington et al. 2018, McBride et al. 2017). In this regard, strengthening property rights could provide a mechanism to secure communities' long-term survival, by buttressing against private investors moving into upland areas, mitigating top-down control by governments, and benefiting more widely from new financial streams for conservation (Barnaud et al. 2007, Daconto and Sherpa 2010, Carlsson et al. 2015).

Biodiversity and water provisioning services: Rates of biodiversity loss are expected to continue, both in MtSES and elsewhere. Drivers of biodiversity loss in MtSES include expanding human populations, poor protected area enforcement, and growing energy demands (McBride et al. 2017). For highelevation species, their distribution and community composition will likely change, with northward/uphill migration where habitat is available, establishment of new and/or invasive species, and species adaptation or extinction (Lamarque et al. 2013, Wyborn et al. 2015, Körner et al. 2017). There is also the risk of declining genetic diversity in MtSES because of competition with invasive or exotic species, e.g., high-value eucalyptus replacing conifers, and the introduction of genetically modified organisms (Loibl and Walz 2010). MtSES communities will have to prepare for a world with scarce freshwater resources, especially in light of growing water demands and contamination from agriculture, mining, and manufacturing (Enfors et al. 2008, Oteros-Rozas et al. 2013, UDSM IRA et al. 2016), and altered ground and surface water availability and hydrological flows across elevations with climate change (Mitchell et al. 2015, Jaeger et al. 2017).

\section{What are the benefits of PSP as applied to MtSES?}

\section{Increased learning}

Although learning was rarely explicitly listed as a goal of the PSP process, there is unmet potential for learning to be a valuable outcome. In our evaluation of process and outcomes (Step 9), studies indicated that participants learned by integrating diverse views, understanding the local context, and comparing trajectories of change in and across MtSES. PSP improves social learning (Keen et al. 2005, Reed et al. 2010) and systems thinking (Dyball et al. 2007, Keen and Mahanty 2006), allowing stakeholders to better understand complexities that exist in MtSES. Many of these processes can be used to foster strategic foresight, encouraging learning from past events (Carlsson et al. 2015, Seidl 2015). The PSP process can thus be as important as the outcome. Yet, papers rarely present post-hoc evidence to demonstrate this learning, and the resulting benefits are generally inferred rather than clearly evidenced. We identify the need for more follow-up research to discover whether participants perceive lasting benefits from the PSP process well after it has concluded. 
The inclusion of diverse actors in decision making

PSP in MtSES is being used predominantly as a tool to build cooperation and collaboration, shared understanding, and decision support (Step 1). However, there is often low participation in terms of diversity and number of stakeholders at multiple stages. For example, bi- and multilateral institutions have rarely been included in PSP in MtSES, despite their role in issues such as coordination of international environmental agreements, e.g., in the Himalayas (Daconto and Sherpa 2010). Similarly, less than half of the studies define their study area using political or administrative boundaries (Step 2), even though doing so would potentially make scenarios more easily translatable for policy decisions. Remarkably, studies rarely engage nonacademics to define system boundaries and develop questions to be addressed (Step 2), even though these actors are often the intended end-users of the results. By not doing so, PSP may bias patterns of international cooperation and budget allocation, leading to unintended consequences for MtSES.

There are a variety of approaches to identify stakeholders for inclusion in PSP research, including stakeholder analysis and actor mapping, based on different ways of characterizing stakeholders and their relationships to other stakeholders (Reed et al. 2009). Developing stakeholder proficiency in envisioning can be a time- and engagement-intensive process (Kohler et al. 2017), particularly for isolated MtSES communities who may find it difficult to imagine divergent futures from present/usual conditions because having to select a limited number of drivers of future change might contradict participants' lived experiences in multifunctional MtSES (FAO 2015). Yet, local knowledge can provide critical insights into MtSES processes (e.g., Klein et al. 2014, Thorn 2019, Steger et al. 2020), and the inclusion of diverse actors in PSP is essential for understanding and managing appropriate future trajectories of MtSES that fulfill the needs and desires of local communities.

\section{Research collaborations}

Our research indicates that there is currently a limited set of institutions and researchers employing PSP in MtSES. Teambased scientific work is common in MtSES PSP, with $50 \%$ of studies being coauthored by some of the same researchers. Such collaborations could accelerate innovation. However, the limited set of institutions employing PSP in MtSES could indicate geographic and disciplinary biases, influencing how questions are framed, and which variables are assessed, which ultimately affects the outcome of studies (Step 4; Friedman et al. 2018). Similarly, authors' origins or institutional affiliations could impact the locally or regionally relevant understandings of unique MtSES contexts (Karlsson et al. 2007, Wilson et al. 2016). We encourage long-term capacity building in PSP, especially of early career researchers involving both South-North and South-South exchange (Gleeson et al. 2016).

\section{Visibility of scholarship}

Half of the MtSES PSP studies are distributed online without restrictions on use and reuse (Step 8), which is comparable to open-access publishing trends for scientific studies in general (Archambault et al. 2014). Increasing the rate at which MtSES PSP studies are made freely available online would be particularly valuable because of the relevance of PSP research to MtSES practitioners (Oteros-Rozas et al. 2015). Publicly available tools and insights from PSP could enhance knowledge democratization and improve the visibility and impact of PSP scholarship in national, e.g., public safety and risk reduction agencies, and international arenas, e.g., IPCC (Wilson et al. 2016). There are economic models of open access publishing that avoid author processing charges for publishing fees, which is perhaps the primary barrier to open access publishing, although other barriers exist, such as internet access. Knowledge products and methods of dissemination to inform local decision makers, e.g., policy briefs and meetings, can be strengthened alongside open access publishing. In most cases, the target audiences were participants or researchers who developed the scenarios, therefore potentially excluding influential decision makers who lacked the time to commit to these processes. This trend could limit how research outcomes shape stakeholders' ability to take up research and engage in agenda setting. Although it is possible that studies did not necessarily report all their communication outreach, horizontal learning opportunities and nonacademic venues for disseminating research could hasten broader sharing and use of PSP, thereby providing the public with a valuable tool for anticipating global environmental change (Hovland 2003).

\section{What are key gaps of PSP in MtSES, and what can be learned from PSP in other contexts?}

Results from our evaluation point to two key gaps in PSP for MtSES: communicating uncertainty (Step 7) and monitoring and evaluating scenario impacts (Step 9). We found that although most studies mention uncertainty as an underlying rationale to employ PSP, uncertainty is often poorly evaluated. This may lead to misconceptions regarding the level of confidence with which results can be employed in assessments and decision-making processes. Uncertainty in PSP may arise from a variety of sources, including insufficient or erroneous data used to construct and test models, e.g., soil moisture and streamflow at high elevations ( $\mathrm{Wu}$ et al. 2012, Capitani et al. 2016), problems in system understanding, e.g., the functional role of predator species in alpine ecosystems (Mitchell et al. 2015), or not having a full range of perspectives in the participatory workshops. This lack of diverse perspectives can then lead to insufficient representation of underlying processes, e.g., inadequate understanding of strategic national priorities for large-scale electrification (Roy et al. 2019) or low predictability of the system, e.g., random behavior in energy demand or nonlinear shifts from stable states due to eutrophication (Rockström et al. 2009, Carlsson et al. 2015).

The MtSES research community can learn from the wider scientific community operating in other systems to improve the application of PSP in MtSES. The IPBES recommends that types, sources, and levels of uncertainty should always be critically evaluated and communicated regardless of the scenarios' goals, including the degree of confidence in the data and outputs, and the relative probabilities of diverse futures when statistically available. Similarly, the MtSES scientific community should set standards for best practices to provide robust and transparent evaluations of uncertainty and encourage research into new methods and their impact on decision making (Akçakaya et al. 2016, IPBES 2016). Future work should focus on monitoring whether scenario outcomes meet the model purpose and inform indicators for policy impact. It should also focus on evaluating the predictive capacity, learning, and feasibility of policies under different scenarios. Enhanced monitoring and evaluation of the 
benefits of PSP could lead to a positive feedback in which more groups undertake PSP and experience its benefits (McBride et al. 2017).

\section{CONCLUSION}

In this paper we help to frame future developments of MtSES research and application by providing the first systematic review on the state of PSP in MtSES. Results indicate that since 2006, there has been a steady rise in the application of PSP in MtSES, which has helped fill critical gaps in understanding data-scarce regions of the world. Our findings from MtSES indicate the potential for a substantial amount of learning to take place through the PSP process: by integrating diverse views, understanding local contexts, comparing trajectories of change in and across MtSES, highlighting complexities, uncertainties, and interdependencies, and potentially aiding adaptation to global environmental change. PSP can also be a useful tool to build cooperation and collaboration, shared understanding, and decision support. Overall, we found that PSP in MtSES is an inclusive, flexible, adaptable method that can be applied across scales, involving different actors and communication strategies. PSP can therefore help address some of the challenges, or paradoxes, of MtSES. However, because information about the "success" of PSP is not often documented explicitly in published studies, more research is needed to provide an evidence-based understanding of when and how such benefits are realized.

Substantial progress has been made by using PSP to understand potential futures in MtSES, yet certain gaps remain. The geographic coverage of PSP in MtSES remains biased toward European countries, with less focus in Asian, African, and Latin American MtSES, particularly relative to their extent and human population. Transboundary collaborations are lacking, although many MtSES occur across administrative boundaries. PSP has tended to address certain themes, such as governance, economy, land use change, and biodiversity, but not others, such as gender equality, public health and sanitation, permafrost thaw, and the use and trade of medicinal resources, which are increasingly important for sustainable MtSES. The temporal scope of PSP is wide ranging, from near-term (14 y) to long-term ( $90 \mathrm{y})$ horizons, while analyses with nested temporal scales are less common. Though often stated as an intent, our review revealed low participation in terms of diversity and number of stakeholders at multiple stages of PSP, and with a limited set of institutions employing PSP.

To address these shortcomings and enhance effective future application, there is a need to improve the visibility and impact of PSP scholarship in national and international policy arenas, with a wider array of target audiences and systems of knowledge. These improvements could increase stakeholders' ability to take up research and to engage in agenda-setting. Two steps that require more attention in future work are (1) communicating uncertainty and (2) monitoring and evaluating scenario impact. We also encourage long-term capacity building in PSP, especially of early career researchers involving both South-North and South-South exchange to overcome biases in geographic coverage. This development will require substantive investments to expand and connect the MtSES research and practice communities, as well as a shift in scientific funding, regional cooperation, and science-policy frameworks. Achieving a greater degree of integration could involve analyzing systems over longer time periods, larger spatial extents, and expanding comparative research and subsequent assessment of benefits. This will require the MtSES research community to address the entrenched disadvantages of some countries to initiate research projects, and to reduce the logistical and financial burdens of studying across international boundaries. Future research may explore the extent to which PSP facilitated movement toward desired outcomes or decision making in MtSES (recognizing that this could take time to come to fruition) and which planning mechanisms or adaptive governance systems support scenario implementation most effectively. Results of this review may inform communities, organizations, companies, researchers, and governments tasked with anticipating a future without precedent for MtSES, and SES more broadly.

\section{AUTHOR CONTRIBUTIONS}

This study was coordinated by JPRT and JAK. The research questions were originally conceived by JPRT, JAK, RS, AWN, CMT, RM, VC, KAH, CES, and CC, who advised through the project. JPRT conducted title, abstract, and full text screening. Full-text coding was conducted by JPRT, CC, and CES. JPRT, $\mathrm{KAH}$, and CES conducted data analysis and mapping. JPRT, JAK, CES, KAH, CC, RM, and CMT wrote the manuscript. All authors read, revised, and approved the final manuscript.

Responses to this article can be read online at: http://www.ecologyandsociety.org/issues/responses. php/11608

\section{Acknowledgments:}

The National Science Foundation's Research Coordination Networks (RCN), as part of the project Mountain Sentinels Collaborative Network, Grant Agreement Number NSF \#DEB 1414106, supported this work. Thanks are due to research assistants Emily Sinkular, Alissa Allen, and Danielle Palm. We are grateful for the valuable discussions within the Mountain Sentinels Collaborative Network (https://mountainsentinels.org/) workshop held in Oregon, April 2017.

\section{Data Availability Statement:}

All relevant data underlying the findings described in the manuscript are fully available in the appendices.

\section{LITERATURE CITED}

Akçakaya, H. R., H. M. Pereira, G. A. Canziani, C. Mbow, A. Mori, M. G. Palomo, J. Soberón, W. Thuiller, and S. Yachi. 2016. Improving the rigour and usefulness of scenarios and models through ongoing evaluation and refinement. Chapter 8 in IPBES. The methodological assessment report on scenarios and models of biodiversity and ecosystem services of the Intergovernmental Science-Policy Platform on Biodiversity and Ecosystem Services. S. Ferrier, K. N. Ninan, P. Leadley, R. Alkemade, L. A. Acosta, H. R. Akçakaya, L. Brotons, W. W. L. Cheung, V. Christensen, K. A. Harhash, J. Kabubo-Mariara, C. Lundquist, M. 
Obersteiner, H. M. Pereira, G. Peterson, R. Pichs-Madruga, N. Ravindranath, C. Rondinini, and B. A. Wintle, editors. Secretariat of the Intergovernmental Science-Policy Platform on Biodiversity and Ecosystem Services, Bonn, Germany.

Allington, G. R. H., M. E. Fernandez-Gimenez, J. Chen, and D. G. Brown. 2018. Combining participatory scenario planning and systems modeling to identify drivers of future sustainability on the Mongolian Plateau. Ecology and Society 23(2):9. https://doi. org/10.5751/ES-10034-230209

Archambault, E., D. Amyot, P. Deschamps, A. Nicol, F. Provencher, L. Rebout, G. Roberge. 2014. Proportion of open access papers published in peer-reviewed journals at the European and world levels-1996-2013. European Commission, Brussels, Belgium.

Bai, X., S. van der Leeuw, K. O'Brien, F. Berkhout, F. Biermann, E. S. Brondizio, C. Cudennec, J. Dearing, A. Duraiappah, M. Glaser, A. Revkin, W. Steffen, and J. Syvitski. 2016. Plausible and desirable futures in the Anthropocene: a new research agenda. Global Environmental Change 39:351-362. https://doi.org/10.1016/ j.gloenvcha.2015.09.017

Barnaud, C. E., T. Promburom, G. Trebuil, and F. Bousquet. 2007. An evolving simulation and gaming process to facilitate adaptive watershed management. Simulation and Gaming 38:398-420. https://doi.org/10.1177/1046878107300670

Bayfield, N., P. Barancok, M. Furger, M. T. Sebastia, G. Domínguez, M. Lapka, E. Cudlinova, L. Vescovo, D. Ganielle, A. Cernusca, U. Tappeiner, and M. Drösler. 2008. Stakeholder perceptions of the impacts of rural funding scenarios on mountain landscapes across Europe. Ecosystems 11:1368-1382. https://doi.org/10.1007/s10021-008-9197-1

Biggs, R., C. Raudsepp-Hearne, C. Atkinson-Palombo, E. Bohensky, E. Boyd, G. Cundill, H. Fox, S. Ingram, K. Kok, S. Spehar, M. Tengö, D. Timmer, and M. Zurek. 2007. Linking futures across scales: a dialog on multiscale scenarios. Ecology and Society 12(1):17. https://doi.org/10.5751/ES-02051-120117

Binder, C. R., J. Hinkel, P. W. G. Bots, and C. Pahl-Wostl. 2013. Comparison of frameworks for analyzing social-ecological systems. Ecology and Society 18(4):26. https://doi.org/10.5751/ ES-05551-180426

Boakes, E. H., P. J. K. McGowan, R. A. Fuller, D. Chang-qing, N. E. Clark, K. O'Connor, and G. M. Mace. 2010. Distorted views of biodiversity: spatial and temporal bias in species occurrence data. PLoS Biology 8(6):e1000385. https://doi.org/10.1371/ journal.pbio. 1000385

Bogdan, S.-M., I. Pătru-Stupariu, and L. Zaharia. 2016. The assessment of regulatory ecosystem services: the case of the sediment retention service in a mountain landscape in the Southern Romanian Carpathians. Procedia Environmental Sciences 32:12-27. https://doi.org/10.1016/j.proenv.2016.03.008

Bourgoin, J., and J.-C. Castella. 2011. "PLUP FICTION": Landscape simulation for participatory land use planning in Northern Lao PDR. Mountain Research and Development 31:78-88. https://doi.org/10.1659/MRD-JOURNAL-D-10-00129.1
Brand, F. S., R. Seidl, Q. B. Le, J. M. Brändle, and R. W. Scholz. 2013. Constructing consistent multiscale scenarios by transdisciplinary processes: the case of mountain regions facing global change. Ecology and Society 18(2):43. https://doi. org/10.5751/ES-04972-180243

Bruijnzeel, L. A., F. N. Scatena, and L. S. Hamilton. 2011. Tropical montane cloud forests: science for conservation and management. International Hydrology Series. Cambridge University Press, Cambridge, UK. https://doi.org/10.1017/ CBO9780511778384

Brunner, S. H., R. Huber, and A. Grêt-Regamey. 2016. A backcasting approach for matching regional ecosystem services supply and demand. Environmental Modelling and Software 75:439-458. https://doi.org/10.1016/j.envsoft.2015.10.018

Budhathoki, S. S., M. Bhattachan, P. K. Pokharel, M. Bhadra, and E. Van Teijlingen. 2017. Reusable sanitary towels: promoting menstrual hygiene in post-earthquake Nepal. Journal of Family Planning and Reproductive Health Care 43(2):157-159. https://doi. org/10.1136/jfprhc-2016-101481

Capitani, C., W. Garedew, A. Mitiku, G. Berecha, B. T. Hailu, J. Heiskanen, P. Hurskainen, P. J. Platts, M. Siljander, F. Pinard, T. Johansson, and R. Marchant. 2019. Views from two mountains: exploring climate change impacts on traditional farming communities of Eastern Africa highlands through participatory scenarios. Sustainability Science 14(1):191-203. https://doi. org/10.1007/s11625-018-0622-X

Capitani, C., K. Mukama, B. Mbilinyi, I. Malugu, P. K. T. Munishi, N. D. Burgess, P. J. Platts, S. Sallu, and R. Marchant. 2016. From local scenarios to national maps: a participatory framework for envisioning the future of Tanzania. Ecology and Society 21(3):4. https://doi.org/10.5751/ES-08565-210304

Carey, M., O. C. Molden, M. B. Rasmussen, M. Jackson, A. W. Nolin, and B. G. Mark. 2017. Impacts of glacier recession and declining meltwater on mountain societies. Annals of the American Association of Geographers 107(2):350-359. https://doi. org/10.1080/24694452.2016.1243039

Carlsson, J., L. O. Eriksson, K. Öhman, and E.-M. Nordström. 2015. Combining scientific and stakeholder knowledge in future scenario development - a forest landscape case study in northern Sweden. Forest Policy and Economics 61:122-134. https://doi. org/10.1016/j.forpol.2015.08.008

Carvalho-Ribeiro, S. M., A. Lovett, and T. O'Riordan. 2010. Multifunctional forest management in northern Portugal: moving from scenarios to governance for sustainable development. Land Use Policy 27:1111-1122. https://doi.org/10.1016/j.landusepol.2010.02.008

Chignell, S. M., and M. J. Laituri. 2016. Telecoupling, urbanization, and the unintended consequences of water development aid in Ethiopia. Pages 125-135 in G. R. Wessel and J. K. Greenberg, editors. Geoscience for the public good and global development: toward a sustainable future. Special Paper 520. Geological Society of America, Boulder, Colorado, USA. https:// doi.org/10.1130/2016.2520(13)

Collaboration for Environmental Evidence (CEE). 2013. Guidelines for systematic reviews in environmental management. CEE, Bangor, UK. 
Cuni-Sanchez, A., P. Omeny, M. Pfeifer, L. Olaka, M. B. Mamo, M., R. Marchant, and N. D. Burgess. 2018. Climate change and pastoralists: perceptions and adaptation in montane Kenya. Climate and Development 11(6):513-524. https://doi. org/10.1080/17565529.2018.1454880

Daconto, G., and L. N. Sherpa. 2010. Applying scenario planning to park and tourism management in Sagarmatha National Park, Khumbu, Nepal. Mountain Research and Development 30:103-112. https://doi.org/10.1659/MRD-JOURNAL-D-09-00047.1

Dyball, R., V. A. Brown, and M. Keen. 2007. Towards sustainability: five strands of social learning. Pages 181-194 in A. E. J. Wals, editor. Social learning towards a sustainable world. Wageningen Academic, Wageningen, The Netherlands.

Encalada, A. C., A. S. Flecker, N. LeRoy Poff, E. Suárez, G. A. Herrera-R, B. Ríos-Touma, S. Jumani, E. I. Larson, and E. P. Anderson. 2019. A global perspective on tropical montane rivers. Science 365(6458):1124-1129. https://doi.org/10.1126/science. $\underline{\operatorname{aax} 1682}$

Enfors, E. I., L. J. Gordon, G. D. Peterson, and D. Bossio. 2008. Making investments in dryland development work: participatory scenario planning in the Makanya catchment, Tanzania. Ecology and Society 13(2):42. https://doi.org/10.5751/ES-02649-130242

Environmental Systems Research Institute (ESRI). 2015. Desktop: Release 10. ESRI, Redlands, California, USA.

Fischler, H. K., M. Getchell, and D. B. Jacobs. 2016. Developing future scenarios in fire prone landscapes of Central Oregon: a stakeholder analysis of what could be. Institute of Natural Resources, Oregon State University, Corvallis, Oregon, USA.

Folke, C. 2007. Social-ecological systems and adaptive governance of the commons. Ecological Research 22:14-15. https://doi.org/10.1007/s11284-006-0074-0

Food and Agricultural Organization (FAO). 2015. Mapping the vulnerability of mountain peoples to food insecurity. R. Romeo, A. Vita, R. Testolin, and T. Hofer, editors. FAO, Rome, Italy.

Food and Agriculture Organization and UN Convention to Combat Desertification (FAO and UNCCD). 2019. Vulnerability to food insecurity in mountain regions: land degradation and other stressors. FAO and UNCCD, Bonn, Germany.

Friedman, R. S., E. A. Law, N. J. Bennett, C. D. Ives, J. P. R. Thorn, and K. A. Wilson. 2018. How just and just how? A systematic review of social equity in conservation research. Environmental Research Letters 13:5. https://doi.org/10.1088/1748-9326/ aabcde

Game, E. T., P. Kareiva, and H. P. Possingham. 2013. Six common mistakes in conservation priority setting. Conservation Biology 27 (3):480-485. https://doi.org/10.1111/cobi.12051

Gardner, J. S., and J. Dekens. 2007. Mountain hazards and the resilience of social-ecological systems: lessons learned in India and Canada. Natural Hazards 41:317-336. https://doi. org/10.1007/s11069-006-9038-5

Gleeson, E. H., S. Wymann von Dach, C. G. Flint, G. B. Greenwood, M. F. Price, J. Balsiger, A. Nolin, and V. Vanacker. 2016. Mountains of our future earth: defining priorities for mountain research - a synthesis from the 2015 Perth III Conference. Mountain Research and Development 36(4):537-548. https://doi.org/10.1659/mrd-journal-d-16-00094.1

Glorioso, R. S., and L. A. G. Moss. 2007. Amenity migration to mountain regions: current knowledge and a strategic construct for sustainable management. Social Change 37(1):137-161. https://doi.org/10.1177/004908570703700108

Hagedorn, F., K. Gavazov, and J. M. Alexander. 2019. Aboveand belowground linkages shape responses of mountain vegetation to climate change. Science 365:1119-1123. https://doi. org/10.1126/science.aax4737

Harrison, P. A., M. Vandewalle, M. T. Sykes, P. M. Berry, R. Bugter, F. de Bello, C. K. Feld, U. Grandin, R. Harrington, J. R. Haslett, R. H. G. Jongman, G. W. Luck, P. M. da Silva, M. Moora, J. Settele, J. P. Sousa, and M. Zobel. 2010. Identifying and prioritizing services in European terrestrial and freshwater ecosystems. Biodiversity and Conservation 19:2791-2821. https:// doi.org/10.1007/s10531-010-9789-X

Helmer, E. H., E. A. Gerson, L. S. Baggett, B. J. Bird, T. S. Ruzycki, and S. M. Voggesser. 2019. Neotropical cloud forests and páramo to contract and dry from declines in cloud immersion and frost. PLoS ONE 14(4):e0213155. https://doi.org/10.1371/journal. pone. 0213155

Holling, C. S., and C. R. Allen. 2002. Adaptive inference for distinguishing credible from incredible patterns in nature. Ecosystems 5:319-328. https://doi.org/10.1007/s10021-001-0076-2

Hopping, K. A., S. M. Chignell, and E. F. Lambin. 2018. The demise of caterpillar fungus in the Himalayan region due to climate change and overharvesting. Proceedings of the National Academy of Sciences 115(45):11489-11494. https://doi.org/10.1073/ pnas. 1811591115

Hovland, I. 2003. Communication of research for poverty reduction: a literature review. Overseas Development Institute, London, UK.

Hubacek, K., and D. S. Rothman. 2005. Review of theory and practice with respect to building and assessing scenarios. WP6 of RELU project, Achieving sustainable catchment management: developing integrated approaches and tools to inform future policies. ESRC, NERC, BBSRC. RES-224-25-0081.

Huber, R., A. Rigling, P. Bebi, F. S. Brand, S. Briner, A. Buttler, C. Elkin, F. Gillet, A. Grêt- Regamey, C. Hirschi, H. Lischke, R. W. Scholz, R. Seidl, T. Spiegelberger, A. Walz, W. Zimmermann, and H. Bugmann. 2013. Sustainable land use in mountain regions under global change: synthesis across scales and disciplines. Ecology and Society 18(3):36. https://doi.org/10.5751/ES-05499-180336

Intergovernmental Panel on Climate Change (IPCC). 2018. Summary for policymakers. In Global warming of $1.5^{\circ} \mathrm{C}$. An IPCC Special Report on the impacts of global warming of $1.5^{\circ} \mathrm{C}$ above pre-industrial levels and related global greenhouse gas emission pathways, in the context of strengthening the global response to the threat of climate change, sustainable development, and efforts to eradicate poverty. V. Masson-Delmotte, P. Zhai, H. O. Pörtner, D. Roberts, J. Skea, P. R. Shukla, A. Pirani, W. Moufouma-Okia, C. Péan, R. Pidcock, S. Connors, J. B. R. Matthews, Y. Chen, X. Zhou, M. I. Gomis, E. Lonnoy, T. Maycock, M. Tignor, T. 
Waterfield, editors. World Meteorological Organization, Geneva, Switzerland.

Intergovernmental Science-Policy Platform on Biodiversity and Ecosystem Services (IPBES). 2016. Summary for policymakers of the assessment report of the methodological assessment of scenarios and models of biodiversity and ecosystem services. S. Ferrier, K. N. Ninan, P. Leadley, R. Alkemade, L. Acosta-Michlik, H. R. Akçakaya, L. Brotons, W. Cheung, V. Christensen, K. H. Harhash, J. Kabubo-Mariara, C. Lundquist, M. Obersteiner, H. Pereira, G. Peterson, R. Pichs-Madruga, N. H. Ravindranath, C. Rondinini, B. Wintle, editors. Secretariat of the Intergovernmental Science-Policy Platform on Biodiversity and Ecosystem Services, Bonn, Germany.

Jaeger, W. K., A. Amos, D. P. Bigelow, H. Chang, D. R. Conklin, R. Haggerty, C. Langpap, K. Moore, P. W. Mote, A. W. Nolin, A. J. Plantinga, C. L. Schwartz, D. Tullos, and D. P. Turner. 2017. Finding water scarcity amid abundance using human-natural system models. Proceedings of the National Academy of Sciences 114(45):11884-11889. https://doi.org/10.1073/pnas.1706847114

Kahane, A. 2012. Transformative scenario planning: working together to change the future. Berrett-Koehler Publishers, San Francisco, California, USA.

Karagulle, D., C. Frye, R. Sayre, S. Breyer, P. Aniello, R. Vaughan, and D. Wright. 2017. Modeling global Hammond landform regions from 250-m elevation data. Transactions in GIS 2 (5):1040-1060. https://doi.org/10.1111/tgis.12265

Karlsson, S., T. Srebotnjak, and P. Gonzales. 2007. Understanding the North-South knowledge divide and its implications for policy: a quantitative analysis of the generation of scientific knowledge in the environmental sciences. Environmental Science and Policy 10:668-684. https://doi. org/10.1016/j.envsci.2007.04.001

Keen, M., V. A. Brown, and R. Dyball. 2005. Social learning in environmental management: towards a sustainable future. Routledge, London, UK.

Keen, M., and S. Mahanty. 2006. Learning in sustainable natural resource management: challenges and opportunities in the Pacific. Society and Natural Resources 19(6):497-513. https://doi. org/10.1080/08941920600663896

Klein, J. A., K. A. Hopping, E. T. Yeh, Y. Nyima, R. B. Boone, and K. A. Galvin. 2014. Unexpected climate impacts on the Tibetan Plateau: local and scientific knowledge in findings of delayed summer. Global Environmental Change 28:141-152. https://doi.org/10.1016/j.gloenvcha.2014.03.007

Klein, J. A., C. M. Tucker, A. W. Nolin, K. A. Hopping, R. S. Reid, C. Steger, A. Grêt-Regamey, S. Lavorel, B. Müller, E. T. Yeh, R. B. Boone, P. Bougeron, V. Bustic, E. Castellanos, X. Chen, S. K. Dong, G. Greenwood, M. Keiler, R. Marchant, R. Seidl, T. Spies, J. Thorn, K. Yager, and the Mountain Sentinels Network. $2019 b$. Catalyzing transformations to sustainability in the world's mountains. Earth's Future 7:547-557. https://doi. org/10.1029/2018ef001024

Klein, J. A., C. M. Tucker, C. E. Steger, A. Nolin, R. Reid, K. A. Hopping, E. T. Yeh, M. S. Pradhan, A. Taber, D. Molden, R. Ghate, D. Choudhury, I. Alcántara-Ayalai, S. Lavorel, B. Müller, A. Grêt-Regamey, R. B. Boone, P. Bourgeron, E. Castellanos, X.
Chen, S. Dong, M. Keiler, R. Seidl, J. P. R. Thorn, and K. Yager. 2019a. An integrated community and ecosystem-based approach to disaster risk reduction in mountain systems. Environmental Science and Policy 94:143-152. https://doi.org/10.1016/j. envsci.2018.12.034

Kohler, M., R. Stotten, M. Steinbacher, G. Leitinger, E. Tasser, U. Schirpke, U. Tappeiner, and M. Schermer. 2017. Participative spatial scenario analysis for alpine ecosystems. Environmental Management 60:679-692. https://doi.org/10.1007/s00267-017-0903-7

Kok, K., and M. van Vliet. 2011. Using a participatory scenario development toolbox: added values and impact on quality of scenarios. Journal of Water and Climate Change 2(2-3):87-105. https://doi.org/10.2166/wcc.2011.032

Kok, M. T. J., K. Kok, G. D. Peterson, R. Hill, J. Agard, and S. R. Carpenter. 2017. Biodiversity and ecosystem services require IPBES to take novel approach to scenarios. Sustainability Science 12:177-181. https://doi.org/10.1007/s11625-016-0354-8

Körner, C., W. Jetz, J. Paulsen, D. Payne, K. Rudmann-Maurer, and E. M. Spehn. 2017. A global inventory of mountains for biogeographical applications. Alpine Botany 127:1-15. https://doi. org/10.1007/s00035-016-0182-6

Körner, C., and M. Ohsawa. 2006. Mountain systems. Pages 681-716 in R. Hassan, R. Scholes, and N. Ash, editors. Ecosystems and human well-being: current state and trends. Island, Washington, D.C., USA.

Lebel, L. 2006. Multi-level scenarios for exploring alternative futures for upper tributary watersheds in mainland Southeast Asia. Mountain Research and Development 26:263-273. https:// doi.org/10.1659/0276-4741(2006)26[263:MSFEAF]2.0.CO;2

Lamarque, P., A. Artaux, C. Barnaud, L. Dobremez, B. Nettier, and S. Lavorel. 2013. Taking into account farmers' decision making to map fine-scale land management adaptation to climate and socio-economic scenarios. Landscape and Urban Planning 119:147-157. https://doi.org/10.1016/j.landurbplan.2013.07.012

Liniger, H., and R. Weingartner. 1998. Mountains and freshwater supply: making the link between mountains, forests and water. Food and Agriculture Organization, Rome, Italy. [online] URL: http:// www.fao.org/3/w9300e/w9300e08.htm

Loibl, W., and A. Walz. 2010. Generic regional development strategies from local stakeholders' scenarios - the Montafon experience. Ecology and Society 15(3):5. https://doi.org/10.5751/ es-03387-150303

Malinga, R., L. J. Gordon, R. Lindborg, and G. Jewitt. 2013. Using participatory scenario planning to identify ecosystem services in changing landscapes. Ecology and Society 18(4):10. https://doi.org/10.5751/ES-05494-180410

Malek, Ž., and L. Boerboom. 2015. Participatory scenario development to address potential impacts of land use change: an example from the Italian Alps. Mountain Research and Development 35(2):126-138. https://doi.org/10.1659/MRD-JOURNALD-14-00082.1

Manfredi, E. C., B. Flury, G. Viviano, S. Thakuri, S. N. Khanal, P. K. Jha, R. K. Maskey, R. B. Kayastha, K. R. Kafle, S. Bhochhibhoya, et al. 2010. Solid waste and water quality 
management models for Sagarmatha National Park and Buffer Zone, Nepal. Mountain Research and Development 30(2):127-142. https://doi.org/10.1659/MRD-JOURNAL-D-10-00028.1

Manuelli, S., T. Hofer, and E. Springgay. 2017. FAO's work in sustainable mountain development and watershed management - a 2017 update. Mountain Research and Development 37 (2):224-227. https://doi.org/10.1659/MRD-JOURNAL-D-17-00043.1

McBride, M. F., K. F. Lambert, E. S. Huff, K. A. Theoharides, P. Field, and J. R. Thompson. 2017. Increasing the effectiveness of participatory scenario development through codesign. Ecology and Society 22(3):16. https://doi.org/10.5751/ES-09386-220316

Meijaard, E., M. Cardillo, E. M. Meijaard, and H. P. Possingham. 2015. Geographic bias in citation rates of conservation research. Conservation Biology 29:920-925. https://doi.org/10.1111/ cobi.12489

Mistry, J., C. Tschirhart, C. Verwer, R. Glastra, O. Davis, D. Jafferally, L. Haynes, R. Benjamin, G. Albert, R. Xavier, I. Bovolo, and A. Berardi. 2014. Our common future? Cross-scalar scenario analysis for social-ecological sustainability of the Guiana Shield, South America. Environmental Science and Policy 44:126-148. https://doi.org/10.1016/j.envsci.2014.05.007

Mitchell, M., M. Lockwood, S. A. Moore, and S. Clement. 2015. Scenario analysis for biodiversity conservation: a socialecological system approach in the Australian Alps. Journal of Environmental Management 150:69-80. https://doi.org/10.1016/j. jenvman.2014.11.013

Moher, D., A. Libertati, J. Tetzlaff, D. G. Altman, and The PRISMA Group. 2009. Preferred reporting items for systematic reviews and meta-analyses: the PRISMA statement. PLOS Medicine 6:e1000097. https://doi.org/10.1371/journal.pmed.1000097

Molden, D., R. Verma, and E. Sharma. 2014. Gender equality as a key strategy for achieving equitable and sustainable development in mountains: the case of the Hindu KushHimalayas. Mountain Research and Development 34(3):297-300. https://doi.org/10.1659/MRD-JOURNAL-D-14-00064

Murphy, D., C. Wyborn, L. Yung, D. R. Williams, C. Cleveland, L. Eby, S. Dobrowski, and E. Towler. 2016. Engaging communities and climate change futures with multi-scale, iterative scenario building (MISB) in the Western United States. Human Organization 75(1):33-46. https://doi.org/10.17730/0018-7259-75.1.33

Nyima, Y., and K. A. Hopping. 2019. Tibetan lake expansion from a pastoral perspective: local observations and coping strategies for a changing environment. Society and Natural Resources 32(9):965-982. https://doi.org/10.1080/08941920.2019.1590667

Oteros-Rozas, E., B. Martín-López, T. Daw, E. L. Bohensky, J. Butler, R. Hill, J. Martin -Ortega, A. Quinlan, F. Ravera, I. RuizMallén, M. Thyresson, J. Mistry, I. Palomo, G. D. Peterson, T. Plieninger, K. A. Waylen, D. Beach, I. C. Bohnet, M. Hamann, J. Hanspach, K. Hubacek, S. Lavorel, and S. Vilardy. 2015. Participatory scenario planning in place-based social-ecological research: insights and experiences from 23 case studies. Ecology and Society 20(4):32. https://doi.org/10.5751/es-07985-200432

Oteros-Rozas, E., B. Martín-López, C. A. López, I. Palomo, and J. A. González. 2013. Envisioning the future of transhumant pastoralism through participatory scenario planning: a case study in Spain. Rangeland Journal 35(3):251-272. https://doi. org/10.1071/RJ12092

Park, L. S., and D. N. Pellow. 2011. The slums of Aspen: immigrants vs. the environment in America's Eden. NYU Press, New York, New York, USA.

Pepin, N., R. Bradley, H. Diaz, M. Baraër, E. Caceres, N. Foresythe, H. Fowler, G. Greenwood, M. Z. Hashmi, X. D. Liu, J. R. Miller, L. Ning, A. Ohmura, E. Palazzi, I. Rangwala, W. Schöner, I. Severskiy, M. Shahgedanova, M. B. Wang, S. N. Williamson, D. Q. Yang, and J. Miller. 2015. Elevation-dependent warming in mountain regions of the world. Nature Climate Change 5(5):424-430.

Peterson, G. D., G. S. Cumming, and S. R. Carpenter. 2003. Scenario planning: a tool for conservation in an uncertain world. Conservation Biology 17:358-366. https://doi.org/10.1046/ j.1523-1739.2003.01491.x

Price, M. F., T. Arnesen, E. Gløersen, and M. J. Metzger. 2018. Mapping mountain areas: learning from global, European and Norwegian perspectives. Journal of Mountain Science 16:1-15. https://doi.org/10.1007/s11629-018-4916-3

Pullin, A. S., M. Bangpan, S. Dalrymple, K. Dickson, N. R. Haddaway, J. R. Healey, H. Hauari, N. Hockley, J. P. G. Jones, T. Knight, C. Vigurs, and S. Oliver. 2013. Human well-being impacts of terrestrial protected areas. Environmental Evidence 2:19.

Rahbek, C., M. K. Borregaard, A. Antonelli, R. K. Colwell, B. G. Holt, D. Nogues-Bravo, C. M. Ø. Rasmussen, K. Richardson, M. T. Rosing, R. J. Whittaker, and J. Fjeldså. 2019b. Building mountain biodiversity: geological and evolutionary processes. Science 365:1114-1119. https://doi.org/10.1126/science.aax0151

Rahbek, C., M. K. Borregaard, R. K. Colwell, B. Dalsgaard, B. G. Holt, N. Morueta-Holme, D. Nogues-Bravo, R. J. Whittaker, and J. Fjeldså. 2019a. Humboldt's enigma: What causes global patterns of mountain biodiversity? Science 365:1108-1113. https://doi.org/10.1126/science.aax0149

Randolph, J. 2008. Online Kappa calculator. [online] URL: http:// justusrandolph.net/kappa/

Rasul, G. 2010. The role of the Himalayan mountain systems in food security and agricultural sustainability in South Asia. International Journal of Rural Management 6(1):95-116. https:// doi.org/10.1177/097300521100600105

Rawluk, A., R. M. Ford, and K. J. H. Williams. 2018. Value-based scenario planning: exploring multifaceted values in natural disaster planning and management. Ecology and Society 23(4):2. https://doi.org/10.5751/ES-10447-230402

Raworth, N. 2012. A safe and just space for humanity: can we live within the doughnut? Oxfam discussion papers. Oxfam, Oxford, UK. https://doi.org/10.1163/2210-7975 hrd-9824-0069

Reed, M. S., A. C. Evely, G. Cundill, I. Fazey, J. Glass, A. Laing, J. Newig, B. Parrish, C. Prell, C. Raymond, and L. C. Stringer. 2010. What is social learning? Ecology and Society 5(14):r1. https://doi.org/10.5751/es-03564-1504r01

Reed, M. S., A. Graves, N. Dandy, H. Posthumus, K. Hubacek, J. Morris, C. Prell, C. H. Quinn, and L. C. Stringer. 2009. Who's 
in and why? A typology of stakeholder analysis methods for natural resource management. Journal of Environmental Management 90:1933-1949. https://doi.org/10.1016/j.jenvman.2009.01.001

Reed, M., J. Kenter, A. Bonn, K. Broad, T. P. Burt, I. R. Fazey, E. D. G. Fraser, K. Hubacek, D. Nainggolan, C. H. Quinn, L. C. Stringer, and F. Ravera. 2013. Participatory scenario development for environmental management: a methodological framework illustrated with experience from the UK uplands. Journal of Environmental Management 128:345-362. https://doi.org/10.1016/ j.jenvman.2013.05.016

Rockström, J., W. Steffen, K. Noone, Å. Persson, F. S. Chapin, III, E. Lambin, T. M. Lenton, M. Scheffer, C. Folke, H. Schellnhuber, B. Nykvist, C. A. De Wit, T. Hughes, S. van de Leeuw, H. Rodhe, S. Sörlin, P. K. Snyder, R. Costanza, U. Svedin, M. Falkenmark, L. Karlberg, R. W. Corell, V. J. Fabry, J. Hansen, B. Walker, D. Liverman, K. Richardson, P. Crutzen, and J. Foley. 2009. Planetary boundaries: exploring the safe operating space for humanity. Ecology and Society 14(2):32. https://doi. org/10.5751/ES-03180-140232

Rodríguez, L. G., N. J. Hogarth, W. Zhou, C. Xie, K. Zhang, and L. Putzel. 2016. China's conversion of cropland to forest program: a systematic review of the environmental and socioeconomic effects. Environmental Evidence 5:21. https://doi.org/10.1186/ $\underline{\text { s13750-016-0071-X }}$

Rosa, I. M. D., H. M. Pereira, S. Ferrier, R. Alkemade, L. A. Acosta, H. R. Akçakaya, E. den Belder, A. M. Fazel, S. Fujimori, M. Harfoot, K. A. Harhash, P. A. Harrison, J. Hauck, R. J. J. Hendriks, G. Hernández, W. Jetz, S. I. Karlsson-Vinkhuyzen, H. Kim, N. King, M. T. J. Kok, G. O. Kolomytsev, T. Lazarova, P. Leadley, C. J. Lundquist, J. García Márquez, C. Meyer, L. M. Navarro, C. Nesshöver, H. T. Ngo, K. N. Ninan, M. G. Palomo, L. M. Pereira, G. D. Peterson, R. Pichs, A. Popp, A. Purvis, F. Ravera, C. Rondinini, J. Sathyapalan, A. M. Schipper, R. Seppelt, J. Settele, N. Sitas, and D. van Vuuren. 2017. Multiscale scenarios for nature futures. Nature Ecology and Evolution 1:1416-1419. https://doi.org/10.1038/s41559-017-0273-9

Rose, A. N., J. L. McKee, M. L. Urban, and E. A. Bright. 2018. LandScan 2017. Oak Ridge National Laboratory, Oak Ridge, Tennessee, USA.

Roy, J., E. Moors, M. S. R. Murthy, S. V. R. K. Prabhakar, B. N. Khattak, P. Shi, C. Huggel, and V. Chitale. 2019. Exploring futures of the Hindu Kush Himalaya: scenarios and pathways. Pages 99-125 in P. Wester, A. Mishra, A. Mukherji, and A. B. Shrestha, editors. The Hindu Kush Himalaya assessment. Springer, Cham, Switzerland. https://doi.org/10.1007/978-3-319-92288-1_4

Sarkki, S., A. Ficko, K. Grunewald, A. P. Kyriazopoulos, and M. Nijnik. 2017. How pragmatism in environmental science and policy can undermine sustainability transformations: the case of marginalized mountain areas under climate and land-use change. Sustainability Science 12:549-561. https://doi.org/10.1007/ $\underline{\text { s11625-016-0411-3 }}$

Sayre, R., C. Frye, D. Karagulle, J. Krauer, S. Breyer, P. Aniello, D. J. Wright, D. Payne, C. Adler, H. Warner, D. P. VanSistine, and J. Cress. 2018. A new high-resolution map of world mountains and an online tool for visualizing and comparing characterizations of global mountain distributions. Mountain
Research and Development 38(3):240-249. https://doi.org/10.1659/ MRD-JOURNAL-D-17-00107.1

Scholtz, R. W., and O. Tietje. 2002. Formative scenario analysis. In Embedded case study methods: integrating quantitative and qualitative knowledge. Sage, Thousand Oaks, California, USA.

Seidl, R. 2015. A functional-dynamic reflection on participatory processes in modeling projects. Ambio 44:750-765. https://doi. org/10.1007/s13280-015-0670-8

Soliva, R., and M. Hunziker. 2009. Beyond the visual dimension: using ideal type narratives to analyse people's assessments of landscape scenarios. Land Use Policy 26:284-294. https://doi. org/10.1016/j.landusepol.2008.03.007

Star, J., E. L. Rowland, M. E. Black, C. A. F. Enquist, G. Garfin, C. H. Hoffman, H. Hartmann, K. L. Jacobs, R. H. Moss, and A. M. Waple. 2016. Supporting adaptation decisions through scenario planning: enabling the effective use of multiple methods. Climate Risk Management 13:88-94. https://doi.org/10.1016/j. crm.2016.08.001

Steger, C., G. Nigussie, M. Alonzo, B. Warkineh, J. Van Den Hoek, M. Fekadu, P. H. Evangelista, and J. A. Klein. 2020. Knowledge coproduction improves understanding of environmental change in the Ethiopian highlands. Ecology and Society 25(2):2. https:// doi.org/10.5751/ES-11325-250202

Thorn, J. P. R. 2019. Adaptation "from below" to changes in species distribution, habitat and climate in agro-ecosystems in the Terai Plans of Nepal. Ambio 48:1482-1497. https://doi. org/10.1007/s13280-019-01202-0

Thorn, J. P. R., R. Friedman, D. Benz, K. J. Willis, and G. Petrokofsky. 2016. What evidence exists for the effectiveness of on-farm conservation land management strategies for preserving ecosystem services in developing countries? A systematic map. Environmental Evidence 5:13. https://doi.org/10.1186/s13750-016-0064-9

Tzanopoulos, J., A. S. Kallimanis, I. Bella, L. Labrianidis, S. Sgardelis, and J. D. Pantis. 2011. Agricultural decline and sustainable development on mountain areas in Greece: sustainability assessment of future scenarios. Land Use Policy 28:585-593. https://doi.org/10.1016/j.landusepol.2010.11.007

University of Dar es Salaam Institute of Resource Assessment (UDSM IRA), Michigan State University, and Agrible, Inc. 2016. Crop and water management under climate change: scenario analysis. USAID, Dar es Salaam, Tanzania.

van der Heijden, K. 1996. Scenarios: the art of strategic conversation. Wiley, New York, New York, USA.

van Notten, P. W. F., J. Rotmans, M. B. A. van Asselt, and D. S. Rothman. 2003. An updated scenario typology. Futures 35:423-443. https://doi.org/10.1016/S0016-3287(02)00090-3

van Vuuren, D. P., M. T. J. Kok, B. Girod, P. L. Lucas, and B. de Vries. 2012. Scenarios in global environmental assessments: key characteristics and lessons for future use. Global Environmental Change 22(4):884-895. https://doi.org/10.1016/j.gloenvcha.2012.06.001

Walker, B., S. Carpenter, J. Anderies, N. Abel, G. S. Cumming, M. Janssen, L. Lebel, J. Norberg, G. D. Peterson, and R. Pritchard. 2002. Resilience management in social-ecological 
systems: a working hypothesis for a participatory approach. Ecology and Society 6(1):14. https://doi.org/10.5751/ES-00356-060114

Walz, A., J. M. Braendle, D. J. Lang, F. Brand, S. Briner, C. Elkin, C. Hirschi, R. Huber, H. Lischke, and D. R. Schmatz. 2014. Experience from downscaling IPCC-SRES scenarios to specific national-level focus scenarios for ecosystem service management. Technological Forecasting \& Social Change 86:21-32. https://doi. org/10.1016/j.techfore.2013.08.014

Walz, A., C. Lardelli, H. Behrendt, A. Grêt-Regamey, C. Lundström, S. Kytzia, and P. Bebi. 2007. Participatory scenario analysis for integrated regional modeling. Landscape and Urban Planning 81:114-131. https://doi.org/10.1016/j.landurbplan.2006.11.001

Wilkinson, A. 2009. Scenarios practices: in search of theory. Journal of Futures Studies 13:107-114.

Wilkinson, A., and E. Eidenow. 2008. Evolving practices in environmental scenarios: a new scenario typology. Environmental Research Letters 3:4. https://doi.org/10.1088/1748-9326/3/4/045017

Wilson, K. A., N. A. Auerbach, K. Sam, A. G. Magini, A. S. L. Moss, S. D. Langhans, S. Budiharta, D. Terzano, and E. Meijaard. 2016. Conservation research is not happening where it is most needed. PLoS Biology 14(3):e1002413. https://doi.org/10.1371/ journal.pbio. 1002413

Wu, W., J. S. Clark, and J. M. Vose. 2012. Response of hydrology to climate change in the southern Appalachian Mountains using Bayesian inference. Hydrological processes 28(4):1616-1626. https://doi.org/10.1002/hyp.9677

Wyborn, C., L. Yung, D. Murphy, and D. R. Williams. 2015. Situating adaptation: how governance challenges and perceptions of uncertainty influence adaptation in the Rocky Mountains. Regional Environmental Change 15:669-682. https://doi. org/10.1007/s10113-014-0663-3

Yang, Y., K. A. Hopping, G. Wang, J. Chen, A. Peng, and J. A. Klein. 2018. Permafrost and drought regulate vulnerability of Tibetan Plateau grasslands to warming. Ecosphere 9(5):e02233. https://doi.org/10.1002/ecs2.2233

Zhen, L., X. Deng, Y. Wei, Q. Jiang, Y. Lin, K. Helming, C. Wang, H. J. König, and J. Hu. 2014. Future land use and food security scenarios for the Guyuan district of remote western China. iForest 7:372-384. https://doi.org/10.3832/ifor1170-007

Zimmermann, M., and M. Keiler. 2015. International frameworks for disaster risk reduction: useful guidance for sustainable mountain development? Mountain Research and Development 35(2):195-202. https://doi.org/10.1659/mrd-journald-15-00006.1 
Appendix 1: Scientific expert advisory board for systematic review

\begin{tabular}{|c|c|c|c|c|c|}
\hline No. & Participant name & $\begin{array}{l}\text { Site name and mountain } \\
\text { range }\end{array}$ & Region & Affiliation & Position \\
\hline 1 & Kelly Hopping & $\begin{array}{l}\text { Nyenchentanglha } \\
\text { Mountains, Tibet } \\
\text { Autonomous Region, } \\
\text { China }\end{array}$ & Asia & $\begin{array}{l}\text { Woods Institute for the Environment, } \\
\text { Stanford University }\end{array}$ & Postdoctoral research fellow \\
\hline 2 & Stephanie Kampf & Rockies, Colorado, USA & $\begin{array}{l}\text { North } \\
\text { America }\end{array}$ & $\begin{array}{l}\text { Department of Ecosystem Science and } \\
\text { Sustainability, Colorado State } \\
\text { University }\end{array}$ & Associate Professor \\
\hline 3 & Karina Yager & $\begin{array}{l}\text { Andes in Bolivia and } \\
\text { Peru, Chile }\end{array}$ & $\begin{array}{l}\text { South } \\
\text { America }\end{array}$ & $\begin{array}{l}\text { Sustainability Studies, Stonybrook } \\
\text { University }\end{array}$ & Assistant Professor \\
\hline 4 & Birgit Müller & $\begin{array}{l}\text { High Atlas Mountains, } \\
\text { Morocco }\end{array}$ & Africa & $\begin{array}{l}\text { Helmholtz Centre for Environmental } \\
\text { Research UFZ }\end{array}$ & $\begin{array}{l}\text { Head of Junior Research Group } \\
\text { POLISES }\end{array}$ \\
\hline 5 & Mateja Śmid & $\begin{array}{l}\text { Triglav National Park and } \\
\text { Julian Alps, Slovenia }\end{array}$ & Europe & $\begin{array}{l}\text { Research Centre of Slovenian } \\
\text { Academy of Sciences and Arts, Anton } \\
\text { Melik Geographical Institute }\end{array}$ & Research Fellow \\
\hline 6 & Vishwas Chitale & $\begin{array}{l}\text { Chitwan Annapurna } \\
\text { Landscape, Nepal / } \\
\text { Kailash Sacred } \\
\text { Landscape, Hindu Kush } \\
\text { Himalayas }\end{array}$ & Asia & $\begin{array}{l}\text { International Centre for Integrated } \\
\text { Mountain Development (ICIMOD) }\end{array}$ & $\begin{array}{l}\text { Remote Sensing Analyst- } \\
\text { Ecosystems Geospatial } \\
\text { Solutions }\end{array}$ \\
\hline 7 & Xiaodong Chen & $\begin{array}{l}\text { Qionglai Mountains, } \\
\text { China }\end{array}$ & Asia & $\begin{array}{l}\text { Department of Geography, University } \\
\text { of North Carolina at Chapel Hill }\end{array}$ & $\begin{array}{l}\text { Assistant Professor of } \\
\text { Geography }\end{array}$ \\
\hline 8 & $\begin{array}{l}\text { Claudia } \\
\text { Capitani }\end{array}$ & $\begin{array}{l}\text { Taita Hills, Jimma } \\
\text { Highlands, Kenya }\end{array}$ & Africa & $\begin{array}{l}\text { Department of Environment and } \\
\text { Geography, University of York }\end{array}$ & Research fellow \\
\hline 9 & Julia Klein & $\begin{array}{l}\text { Nyenchentanglha } \\
\text { Mountains, Tibet } \\
\text { Autonomous Region, } \\
\text { China }\end{array}$ & Asia & $\begin{array}{l}\text { Department of Ecosystem Science and } \\
\text { Sustainability, Colorado State } \\
\text { University }\end{array}$ & $\begin{array}{l}\text { Associate Professor, Principal } \\
\text { Investigator }\end{array}$ \\
\hline 10 & Robin Reid & $\begin{array}{l}\text { Kilimanjaro, Tanzania / } \\
\text { Rockies, Colorado, USA }\end{array}$ & $\begin{array}{l}\text { Africa/ } \\
\text { North } \\
\text { America }\end{array}$ & $\begin{array}{l}\text { Center for Collaborative Conservation, } \\
\text { Colorado State University }\end{array}$ & Director, Principal Investigator \\
\hline 11 & $\begin{array}{l}\text { Catherine } \\
\text { Tucker }\end{array}$ & $\begin{array}{l}\text { Sierra Madre de Oaxaca, } \\
\text { Mexico / Santa Barbara } \\
\text { Mountains, Honduras } \\
\end{array}$ & $\begin{array}{l}\text { Central } \\
\text { America }\end{array}$ & $\begin{array}{l}\text { Department of Anthropology and } \\
\text { Center for Latin American Studies, } \\
\text { University of Florida }\end{array}$ & $\begin{array}{l}\text { Associate Professor in } \\
\text { Anthropology, Principal } \\
\text { Investigator }\end{array}$ \\
\hline 12 & Jessica Thorn & $\begin{array}{l}\text { Alps, Switzerland/ Taita } \\
\text { Hills, Kenya }\end{array}$ & $\begin{array}{l}\text { Europe/ } \\
\text { Asia }\end{array}$ & $\begin{array}{l}\text { Department of Ecosystem Science and } \\
\text { Sustainability, Colorado State } \\
\text { University }\end{array}$ & Postdoctoral research fellow \\
\hline 13 & Cara Elizabeth Steger & Guassa Plateau, Ethiopia & Africa & $\begin{array}{l}\text { Department of Ecosystem Science and } \\
\text { Sustainability, Colorado State } \\
\text { University }\end{array}$ & PhD candidate \\
\hline 14 & $\begin{array}{l}\text { Adrienne Grêt- } \\
\text { Regamey }\end{array}$ & Alps, Switzerland & Europe & $\begin{array}{l}\text { Planning Landscapes and Urban } \\
\text { Systems, ETH Zurich }\end{array}$ & Professor \\
\hline 15 & Marty Anderies & $\begin{array}{l}\text { Hindu-Kush Himalayas, } \\
\text { Nepal / Luang Prabang } \\
\text { Mountains, Thailand / } \\
\text { Daba Mountains and } \\
\text { Yungui Plateau, China } \\
\end{array}$ & Asia & $\begin{array}{l}\text { School of Human Evolution and Social } \\
\text { Change, Arizona State University }\end{array}$ & $\begin{array}{l}\text { Professor and Graduate } \\
\text { Director }\end{array}$ \\
\hline 16 & $\begin{array}{l}\text { Edmund } \\
\text { Mabhuye }\end{array}$ & $\begin{array}{l}\text { Eastern Arc Mountains, } \\
\text { Tanzania }\end{array}$ & Africa & $\begin{array}{l}\text { Institute of Resource Assessment, } \\
\text { University of Dar es Salaam }\end{array}$ & Director \\
\hline 17 & $\begin{array}{l}\text { Christopher Liam } \\
\text { Cosgrove }\end{array}$ & $\begin{array}{l}\text { Wrangell St Elias } \\
\text { Mountain Range, Alaska, } \\
\text { USA }\end{array}$ & $\begin{array}{l}\text { North } \\
\text { America }\end{array}$ & $\begin{array}{l}\text { Mountain Hydro-climatology Group, } \\
\text { Oregon State University }\end{array}$ & PhD Candidate \\
\hline 18 & Bryan Mark & Tropical Andes, Peru & $\begin{array}{l}\text { North } \\
\text { America }\end{array}$ & $\begin{array}{l}\text { Geography and Byrd Polar and } \\
\text { Climate Research Centre, Ohio State } \\
\text { University }\end{array}$ & Professor \\
\hline 19 & Tom Spies & $\begin{array}{l}\text { Cascades and Coast } \\
\text { Range, Oregon, USA }\end{array}$ & $\begin{array}{l}\text { North } \\
\text { America }\end{array}$ & $\begin{array}{l}\text { USDA Forest Service/Oregon State } \\
\text { University }\end{array}$ & $\begin{array}{l}\text { Senior Scientist/Courtesy } \\
\text { Faculty }\end{array}$ \\
\hline 20 & Dave Conklin & Cascades, Oregon, USA & $\begin{array}{l}\text { North } \\
\text { America }\end{array}$ & $\begin{array}{l}\text { Freshwater Simulations, Conklin } \\
\text { Biology Institute, Oregon State } \\
\text { University }\end{array}$ & Consultant \\
\hline 21 & Anne Nolin & Cascades, Oregon, USA & $\begin{array}{l}\text { North } \\
\text { America }\end{array}$ & $\begin{array}{l}\text { College of Earth, Ocean, and } \\
\text { Atmospheric Sciences, Oregon State } \\
\text { University }\end{array}$ & Professor, Principal Investigator \\
\hline 22 & Thea Weiss Hayes & Cascades, Oregon, USA & $\begin{array}{l}\text { North } \\
\text { America }\end{array}$ & Portland Public Schools & $\begin{array}{l}\text { Retired Science Teacher (Plus } \\
\text { Health, Math, Reading, Social } \\
\text { Studies, Electives) }\end{array}$ \\
\hline 23 & Jamie Rumage & Cascades, Oregon, USA & $\begin{array}{l}\text { North } \\
\text { America }\end{array}$ & Oregon Department of Education & Science Education Specialist \\
\hline
\end{tabular}




\begin{tabular}{|c|c|c|c|}
\hline No. & Web of Science (WOS) Test string results & $\begin{array}{l}\text { Search } \\
\text { results }\end{array}$ & Date \\
\hline 1 & $\begin{array}{l}\text { ("scenario analy*" OR "scenario develop*" OR "scenario planning" OR } \\
\text { "scenario") AND TOPIC: ("mountain*") AND TOPIC: ("participat*model*") ORTOPIC: ("socio- } \\
\text { ecological system") OR TOPIC: ("transdisciplinary" OR "interdisciplinary" OR } \\
\text { "multidisciplinary") OR TITLE:("stakeholder") - Refined by: TOPIC: ("climate change") }\end{array}$ & 2092 & $\begin{array}{l}\text { August 13, } \\
2017\end{array}$ \\
\hline 2 & scenario analy* OR "scenario develop*" OR "scenario planning" OR "scenario" & 181012 & $\begin{array}{l}\text { August 13, } \\
2017\end{array}$ \\
\hline 3 & $\begin{array}{l}\text { ("scenario analy*" OR "scenario develop*" OR "scenario planning" OR } \\
\text { "scenario") AND TOPIC: ("mountain*") }\end{array}$ & 1629 & $\begin{array}{l}\text { August 13, } \\
2017\end{array}$ \\
\hline 4 & $\begin{array}{l}\text { ("scenario analy*" OR "scenario develop*" OR "scenario planning" OR } \\
\text { "scenario") AND TOPIC: ("mountain*") Refined by: TOPIC: ("socio-ecological") }\end{array}$ & 4 & $\begin{array}{l}\text { August 13, } \\
2017\end{array}$ \\
\hline 5 & $\begin{array}{l}\text { ("scenario analy*" OR "scenario develop*" OR "scenario planning" OR } \\
\text { "scenario") AND TOPIC: ("mountain*") AND TOPIC: ("participat*model*") ORTOPIC: ("socio- } \\
\text { ecological system") OR TOPIC: ("transdisciplinary" OR "interdisciplinary" OR } \\
\text { "multidisciplinary") OR TITLE:("stakeholder") }\end{array}$ & 130944 & $\begin{array}{l}\text { August 13, } \\
2017\end{array}$ \\
\hline 6 & $\begin{array}{l}\text { ("scenario analy*" OR "scenario develop*" OR "scenario planning" OR } \\
\text { "scenario") AND TOPIC: ("mountain*") AND TOPIC: ("participat*model*" OR "model" OR } \\
\text { "socio-ecological") }\end{array}$ & 797 & $\begin{array}{l}\text { August 13, } \\
2017\end{array}$ \\
\hline 7 & $\begin{array}{l}\text { ("scenario analy*" OR "scenario develop*" OR "scenario planning" OR } \\
\text { "scenario") AND TOPIC: ("mountain*") AND TOPIC: ("participat*model*" OR "model" OR } \\
\text { "socio-ecological") } A N D \text { TOPIC: ("case" or "place-based" OR "landscape") }\end{array}$ & 201 & $\begin{array}{l}\text { August 13, } \\
2017\end{array}$ \\
\hline 8 & $\begin{array}{l}\text { ("scenario analy*" OR "scenario develop*" OR "scenario planning" OR } \\
\text { "scenario") AND TOPIC: ("mountain*") AND TOPIC: ("participat*model*" OR "model" OR } \\
\text { "socio-ecological") ANDTOPIC: ("case" or "place-based" OR "landscape" OR "land use") }\end{array}$ & 263 & $\begin{array}{l}\text { August 13, } \\
2017\end{array}$ \\
\hline 9 & $\begin{array}{l}\text { ("scenario analy*" OR "scenario develop*" OR "scenario planning" OR } \\
\text { "scenario") AND TOPIC: ("mountain*") AND TOPIC: ("participat*model*" OR "model" OR } \\
\text { "socio-ecological") ANDTOPIC: ("case" or "place-based" OR "landscape") AND TOPIC: ("climate } \\
\text { change" OR "ecosystem servic*" OR "land use") }\end{array}$ & 120 & $\begin{array}{l}\text { August 13, } \\
2017\end{array}$ \\
\hline 10 & $\begin{array}{l}\text { ("scenario analy*" OR "scenario develop*" OR "scenario planning" OR } \\
\text { "scenario") } A N D \text { TOPIC: ("mountain*") AND TOPIC: ("participat*model*" OR "model" OR } \\
\text { "socio-ecological") } A N D \text { TOPIC: ("case" or "place-based" OR "landscape" OR "land } \\
\text { use") } A N D \text { TOPIC: ("climate change" OR "ecosystem servic*") }\end{array}$ & 132 & $\begin{array}{l}\text { August 13, } \\
2017\end{array}$ \\
\hline 11 & $\begin{array}{l}\text { ("scenario analy*" OR "scenario develop*" OR "scenario planning" OR } \\
\text { "scenario") AND TOPIC: ("mountain*") AND TOPIC: ("participat*model*" OR "model" OR } \\
\text { "socio-ecological") ANDTOPIC: ("climate change" OR "ecosystem servic*") }\end{array}$ & 400 & $\begin{array}{l}\text { August 13, } \\
2017\end{array}$ \\
\hline 12 & $\begin{array}{l}\text { ("scenario analy*" OR "scenario develop*" OR "scenario planning" OR } \\
\text { "scenario") AND TOPIC: ("mountain*") AND TOPIC: ("participat*model*" OR "model" OR } \\
\text { "socio-ecological") ANDTOPIC: ("climate change" OR "ecosystem servic*") AND TOPIC:("case" } \\
\text { OR "landuse") }\end{array}$ & 49 & $\begin{array}{l}\text { August 13, } \\
2017\end{array}$ \\
\hline 13 & $\begin{array}{l}\text { ("scenario analy*" OR "scenario develop*" OR "scenario planning" OR } \\
\text { "scenario") } A N D \text { TOPIC: ("mountain*") AND TOPIC: ("participat*model*" OR "model" OR } \\
\text { "socio-ecological") AND TOPIC: ("climate change" OR "ecosystem servic*") AND TOPIC: ("case" } \\
\text { OR "landuse" OR "place" OR "landscape") }\end{array}$ & 99 & $\begin{array}{l}\text { August 13, } \\
2017\end{array}$ \\
\hline 14 & $\begin{array}{l}\text { ("scenario analy" OR "scenario develop*" OR "scenario planning" OR } \\
\text { "scenario") } A N D \text { TOPIC: ("mountain*") AND TOPIC: ("participat*model*" OR "model" OR } \\
\text { "socio-ecological") AND TOPIC: ("climate change" OR "ecosystem servic*") AND TOPIC: ("case" } \\
\text { OR "landuse" OR "place" OR "landscape") AND TITLE: ("resilience" OR "adaptation") }\end{array}$ & 2 & $\begin{array}{l}\text { August 13, } \\
2017\end{array}$ \\
\hline 15 & $\begin{array}{l}\text { TOPIC:("scenario analy*" OR "scenario develop*" OR "scenario plan*" OR } \\
\text { "scenario") AND TOPIC: ("mountain*") AND TOPIC: ("participat*" OR } \\
\text { "collaborat*") AND TOPIC: ("socio-ecologic*" OR "social-ecologic*" OR "coupled human- } \\
\text { natural" OR "human-environ*") AND TOPIC: ("case" OR "place-based" OR "landscape") }\end{array}$ & 4 & $\begin{array}{l}\text { September } \\
5,2017\end{array}$ \\
\hline 16 & $\begin{array}{l}\text { TOPIC:("scenario analy*" OR "scenario develop*" OR "scenario plan*" OR } \\
\text { "scenario") } A N D \text { TOPIC: ("mountain*") } A N D \text { TOPIC: ("participat*" OR } \\
\text { "collaborat*") AND TOPIC: ("socio-ecologic*" OR "social-ecologic*" O' } \\
\text { R "coupled human-natural" OR "human-environ*") AND TOPIC: ("case" OR "place-based") }\end{array}$ & 2 & $\begin{array}{l}\text { September } \\
5,2017\end{array}$ \\
\hline 17 & $\begin{array}{l}\text { TOPIC:("scenario analy*" OR "scenario develop*" OR "scenario plan*" OR } \\
\text { "scenario") AND TOPIC: ("mountain*") AND TOPIC: ("participat*" OR } \\
\text { "collaborat*") AND TOPIC: ("socio-ecologic*" OR "social-ecologic*" OR "coupled human- } \\
\text { natural" OR "human-environ*") }\end{array}$ & 5 & $\begin{array}{l}\text { September } \\
5,2017\end{array}$ \\
\hline 18 & $\begin{array}{l}\text { TOPIC:("scenario analy*" OR "scenario develop*" OR "scenario plan*" OR } \\
\text { "scenario") } A N D \text { TOPIC: ("mountain*") } A N D \text { TOPIC: ("participat*" OR } \\
\text { "collaborat*") } A N D \text { TOPIC: ("socio-ecologic*" OR "social-ecologic**" OR "human-environ*") }\end{array}$ & 5 & $\begin{array}{l}\text { September } \\
5,2017\end{array}$ \\
\hline 19 & $\begin{array}{l}\text { TOPIC:("scenario analy*" OR "scenario develop*" OR "scenario plan*" OR } \\
\text { "scenario") AND TOPIC: ("mountain*") AND TOPIC: ("participat*" OR } \\
\text { "collaborat*") AND TOPIC: ("socio-ecologic*" OR "social-ecologic*" OR "human- } \\
\text { environ*") AND TOPIC:("case" OR "place-based" OR "landscape") }\end{array}$ & 4 & $\begin{array}{l}\text { September } \\
5,2017\end{array}$ \\
\hline
\end{tabular}




\begin{tabular}{|c|c|c|c|}
\hline 20 & $\begin{array}{l}\text { TOPIC:("scenario analy*" OR "scenario develop*" OR "scenario plan*" OR } \\
\text { "scenario") AND TOPIC: ("mountain*") AND TOPIC: ("participat*" OR } \\
\text { "collaborat*") AND TOPIC: ("case" OR "place-based" OR "landscape") }\end{array}$ & 25 & $\begin{array}{l}\text { September } \\
5,2017\end{array}$ \\
\hline 21 & $\begin{array}{l}\text { TOPIC:("scenario analy*" OR "scenario develop*" OR "scenario plan*" OR } \\
\text { "scenario") AND TOPIC: ("mountain*") AND TOPIC: ("participat*" OR } \\
\text { "collaborat*") AND TOPIC: ("case") }\end{array}$ & 14 & $\begin{array}{l}\text { September } \\
5,2017\end{array}$ \\
\hline 22 & $\begin{array}{l}\text { TOPIC:("scenario analy*" OR "scenario develop*" OR "scenario plan*" OR } \\
\text { "scenario") AND TOPIC: ("mountain*") AND TOPIC: ("participat*" OR } \\
\text { "collaborat*") AND TOPIC:("landscape") }\end{array}$ & 20 & $\begin{array}{l}\text { September } \\
5,2017\end{array}$ \\
\hline 23 & $\begin{array}{l}\text { TOPIC:("scenario analy*" OR "scenario develop*" OR "scenario plan*" OR } \\
\text { "scenario") AND TOPIC: ("mountain*") AND TOPIC: ("participat*") }\end{array}$ & 31 & $\begin{array}{l}\text { September } \\
5,2017\end{array}$ \\
\hline 24 & $\begin{array}{l}\text { TOPIC:("scenario analy*" OR "scenario develop*" OR "scenario plan*" OR } \\
\text { "scenario") AND TOPIC: ("mountain*") AND TOPIC: ("collaborat*") }\end{array}$ & 13 & $\begin{array}{l}\text { September } \\
5,2017\end{array}$ \\
\hline 25 & $\begin{array}{l}\text { TOPIC:("scenario analy*" OR "scenario develop*" OR "scenario plan*" OR } \\
\text { "scenario") } A N D \text { TOPIC: ("mountain*") } A N D \text { TOPIC: ("participat*" OR } \\
\text { "collaborat*") } A N D \text { TOPIC: ("socio-ecologic*") }\end{array}$ & 1 & $\begin{array}{l}\text { September } \\
5,2017\end{array}$ \\
\hline 26 & $\begin{array}{l}\text { TOPIC:("scenario analy*" OR "scenario develop*" OR "scenario plan*" OR } \\
\text { "scenario") } A N D \text { TOPIC: ("mountain*") } A N D \text { TOPIC: ("participat*" OR } \\
\text { "collaborat*") AND TOPIC: ("socio-ecologic*" OR "social-ecologic*" OR "coupled human- } \\
\text { natural" OR "human-environ*" OR "complex*") }\end{array}$ & 9 & $\begin{array}{l}\text { September } \\
5,2017\end{array}$ \\
\hline 27 & $\begin{array}{l}\text { TOPIC:("scenario analy*" OR "scenario develop*" OR "scenario planning" OR } \\
\text { "scenario") AND TOPIC: ("mountain*") }\end{array}$ & 1640 & $\begin{array}{l}\text { September } \\
5,2017\end{array}$ \\
\hline 28 & $\begin{array}{l}\text { ("scenario analy*" OR "scenario develop*" OR "scenario planning" OR } \\
\text { "scenario") } A N D \text { TOPIC: ("mountain*") } A N D \text { TOPIC: ("socio-ecolog*") } \\
\end{array}$ & 4 & $\begin{array}{l}\text { September } \\
5,2017\end{array}$ \\
\hline 29 & $\begin{array}{l}\text { TOPIC:("scenario analy*" OR "scenario develop*" OR "scenario planning" OR } \\
\text { "scenario") AND TOPIC: ("mountain*") AND TOPIC: ("socio-ecolog*") ANDTOPIC: ("case") }\end{array}$ & 2 & $\begin{array}{l}\text { September } \\
5,2017\end{array}$ \\
\hline 30 & $\begin{array}{l}\text { TOPIC:("scenario analy*" OR "scenario develop*" OR "scenario plan*" OR } \\
\text { "scenario") } A N D \text { TOPIC: ("mountain*") AND TOPIC: ("participat*" OR "collaborat*") AND } \\
\text { TOPIC "model" }\end{array}$ & 26 & $\begin{array}{l}\text { September } \\
8,2017\end{array}$ \\
\hline 31 & $\begin{array}{l}\text { TOPIC:("scenario analy*" OR "scenario develop*" OR "scenario plan*" OR } \\
\text { "scenario") AND TOPIC: ("mountain*") AND TOPIC: ("participat*") AND TIOPIC "model: }\end{array}$ & 4 & $\begin{array}{l}\text { September } \\
8,2017\end{array}$ \\
\hline 32 & $\begin{array}{l}\text { ("scenario analy*" OR "scenario develop*" OR "scenario planning" OR } \\
\text { "scenario) } A N D \text { TOPIC: ("mountain*") } A N D \text { TOPIC: ("participat*model*" OR } \\
\text { "participat*") } A N D \text { TOPIC: ("socio-ecologic*" OR "social-ecologic*" OR "coupled human-natural" } \\
\text { OR "human-environ*) }\end{array}$ & 5,751 & $\begin{array}{l}\text { September } \\
8,2017\end{array}$ \\
\hline 33 & $\begin{array}{l}\text { ("scenario analy*" OR "scenario develop*" OR "scenario planning" OR } \\
\text { "scenario) } A N D \text { TOPIC: ("mountain*") AND TOPIC: ("participat*model*" OR } \\
\text { "participat*") AND TOPIC: ("socio-ecologic*" OR "social-ecologic*" OR "coupled human-natural" } \\
\text { OR "human-environ*) }\end{array}$ & 5,751 & $\begin{array}{l}\text { September } \\
8,2017\end{array}$ \\
\hline 34 & $\begin{array}{l}\text { TOPIC:("scenario analy*" OR "scenario develop*" OR "scenario planning" OR } \\
\text { "scenario") AND TOPIC: ("participat*") AND TOPIC: ("socio-ecological" OR "social- } \\
\text { ecological") AND TOPIC:("case" OR "place-based" OR "landscape") AND TOPIC:("mountain" }\end{array}$ & 4 & $\begin{array}{l}\text { September } \\
8,2017\end{array}$ \\
\hline 35 & $\begin{array}{l}\text { TOPIC:("scenario analy*" OR "scenario develop*" OR "scenario planning" OR } \\
\text { "scenario") AND TOPIC:("participat*model*" OR "model" OR "socio-ecological" OR "social- } \\
\text { ecological") AND TOPIC: ("case" OR "place-based" OR "landscape") ANDTOPIC: ("mountain") }\end{array}$ & 119 & $\begin{array}{l}\text { September } \\
8,2017\end{array}$ \\
\hline 36 & $\begin{array}{l}\text { TOPIC:("scenario analy*" OR "scenario develop*" OR "scenario planning" OR } \\
\text { "scenario") AND TOPIC:("participat*model*" OR "model" OR "socio- } \\
\text { ecological") AND TOPIC:("case" OR "place-based" OR "landscape") AND TOPIC:("mountain") }\end{array}$ & 117 & $\begin{array}{l}\text { September } \\
8,2017\end{array}$ \\
\hline 37 & $\begin{array}{l}\text { TOPIC:("scenario analy*" OR "scenario develop*" OR "scenario planning" OR } \\
\text { "scenario") AND TOPIC:("participat*model*" OR "model" OR "socio- } \\
\text { ecological") AND TOPIC:("case" OR "place-based") ANDTOPIC: ("mountain") }\end{array}$ & 68 & $\begin{array}{l}\text { September } \\
8,2017\end{array}$ \\
\hline 38 & $\begin{array}{l}\text { TOPIC:("scenario analy*" OR "scenario develop*" OR "scenario planning" OR } \\
\text { "scenario") AND TOPIC:("participat*model*" OR "model" OR "socio-ecological" OR "social- } \\
\text { ecological" OR "human-environ*") AND TOPIC: ("stakeholder") ANDTOPIC: ("case" OR "place- } \\
\text { based" OR "landscape") AND TOPIC:("mountain") }\end{array}$ & 4 & $\begin{array}{l}\text { September } \\
8,2017\end{array}$ \\
\hline 39 & $\begin{array}{l}\text { TOPIC:("scenario analy*" OR "scenario develop*" OR "scenario planning" OR } \\
\text { "scenario") AND TOPIC:("participat*model*" OR "model" OR "socio-ecological" OR "social- } \\
\text { ecological" OR "human-environ*") AND TOPIC: ("case" OR "place-based"OR } \\
\text { "landscape") AND TOPIC:("mountain") }\end{array}$ & 120 & $\begin{array}{l}\text { September } \\
5,2017\end{array}$ \\
\hline 40 & $\begin{array}{l}\text { TOPIC:("scenario analy*" OR "scenario develop*" OR "scenario plan*" OR } \\
\text { "scenario") } A N D \text { TOPIC: ("mountain*") AND TOPIC: ("participat*" OR "collaborat*") }\end{array}$ & 43 & $\begin{array}{l}\text { September } \\
5,2017\end{array}$ \\
\hline
\end{tabular}




\section{Appendix 3. Test library}

1. Sarkki, S., A. Ficko, K. Grunewald, A. P. Kyriazopoulos, and M. Nijnik. 2017. How pragmatism in environmental science and policy can undermine sustainability transformations: the case of marginalized mountain areas under climate and land-use change. Sustainability Science 12: 549561.

2. Bogdan, S.-M., I. Pătru-Stupariu, and Zaharia, L. 2016. The assessment of regulatory ecosystem services: the case of the sediment retention service in a mountain landscape in the Southern Romanian Carpathians. Procedia Environmental Sciences 32: 12-27.

3. Capitani, C., K. Mukama, B. Mbilinyi, I. Malugu, P. K. T Munishi, N. D. Burgess, P. J. Platts, S. Sallu, and R. Marchant. 2016. From local scenarios to national maps: a participatory framework for envisioning the future of Tanzania. Ecology and Society 21(3): 5.

4. Palacios-Agundez, I., M. Onaindia, M. Potschin, J. A. Tratalos, I. Madariaga, and R. Haines-Young. 2015. Relevance for decision making of spatially explicit, participatory scenarios for ecosystem services in an area of a high current demand. Environmental Science and Policy 54 (Supplement C): 199-209.

5. Malek, Z., and L. Boerboom. 2015. Participatory scenario development to address potential impacts of land use change: An example from the Italian Alps. Mountain Research and Development 35(2): 126-138.

6. Enache, A., M. Kuhmaier, K. Stampfer, and V. D. Coibanu. 2013. An integrated decision support tool for assessing forest road options in a mountainous region in Romania. Croatian Journal of Forest Engineering 34(1): 43-60.

7. Lippe, M., T. T. Minh, A. Neef, T. Hilger, V. Hoffman, N. T. Lam, and G. Cadisch. 2011. Building on qualitative datasets and participatory processes to simulate land use change in a mountain watershed of Northwest Vietnam. Environmental Modeling and Software 25(12): 1454-1466.

8. Tzanopoulos, J., A. S. Kallimanis, I. Bella, L. Labrianidis, S. Sgardelis, and J. D. Pantis. 2011. 
Agricultural decline and sustainable development on mountain areas in Greece: Sustainability assessment of future scenarios. Land Use Policy 28(3): 585-593.

9. Bajracharya, B., S. Pradhan, S. Basanta, and F. Salerno. 2010. An integrated decision support toolbox (DST) for the management of mountain protected areas. Mountain Research and Development 30(2): 94-102.

10. Daconto, G., and L. N. Sherpa. 2015. Applying scenario planning to park and tourism management in Sagarmatha National Park, Khumbu, Nepal. Mountain Research and Development 30(2): 103-112.

11. Suzuki, N., and K. L. Parker. Potential conflict between future development of natural resources and high-value wildlife habitats in boreal landscapes. Biodiversity and Conservation 25(14): 3043-3073.

12. Soliva, R., and M. Hunziker. 2009. Beyond the visual dimension: Using ideal type narratives to analyse people's assessments of landscape scenarios. Land Use Policy 26(2): 284-294.

13. Soliva, R., K. Rønningen, I. Bella, P. Bezak, T. Cooper, B. E. Flø, P. Marty, and C. Potter. 2008. Envisioning upland futures: Stakeholder responses to scenarios for Europe's mountain landscapes. Journal of Rural Studies 24(1): 56-71.

14. Lamarque, P., A. Artaux, C. Barnaud, L. Dobremez, B. Nettier, and S. Lavorel. 2013. Taking into account farmers' decision making to map fine-scale land management adaptation to climate and socio-economic scenarios. Landscape and Urban Planning 119(Supplement C): 147-157.

15. Bolliger, J., F. Kienast, R. Soliva, and G. Rutherford. 2007. Spatial sensitivity of species habitat patterns to scenarios of land use change (Switzerland). Landscape Ecology 22(5): 773-789.

16. Koo, K. A., S. U. Park, W.-S. Kong, S. Hong, I. Jang, and C. Seo. 2017. Potential climate change effects on tree distributions in the Korean Peninsula: Understanding model and climate uncertainties. Ecological modeling 353: 17-37.

17. Schirpka, U., F. Timmermann, U. Tappeiner, and E. Tasser. 2016. Cultural ecosystem services of mountain regions: Modeling the aesthetic value. Ecological Indicators 69: 78-90. 
18. Bentham, J. 2014. The scenario approach to possible futures for oil and natural gas. Energy Policy 64: 87-92.

19. Soliva, R. 2007. The future of the Swiss Alps: A participatory sustainability assessment of agricultural and landscape scenarios. Gaia-Ecological Perspectives for Science and Society 16(2): 122-129.

20. Vashisht, A. K. 2008. Ingenious techniques for irrigation sustainability in Himalayan and Shiwalik foothill regions. Current Science 95(12): 1688-1693.

21. Salerno, F., G. Viviano, S. Thukari, B. Flury, R. K. Maskey, S. N. Khanal, D. Bhuju, M. Carrer, S. Bhochhibhoya, M. T. Melis, F. Giannino, A. Staiano, F. Carteni, S. Mazzoleni, A. Cogo, A. Sapkota, S. Shresha, and E. C. Manfredi. 2010. Energy, forest and indoor air pollution models for Sagarmatha national park and buffer zone, Nepal implementation of a participatory modeling framework. Mountain Research and Development 30(20): 113-126.

22. Walz, A., C. Lardelli, H. Behrendt, A. Gret-Regamey, C. Lundstrom, S. Kytzia, and P. Bebi. 2007. Participatory scenario analysis for integrated regional modeling. Landscape and Urban Planning 81: 114-131.

23. Palazzi, E., L. Filippi, and J. von Hardenberg. 2017. Insights into elevation- dependent warming in the Tibetan Plateau-Himalayas from CMIP5 model simulations. Climate Dynamics 48(11): $3991-4008$.

24. Accatello, C., B. Filippo, and E. Borgogno-Mondino. 2017. A spatial-based decision support systems for wood harvesting management in mountain areas. Land Use Policy 67: 277-287.

25. Sil, A., A. P. Rodrigues, and C. Carvarlho-Santos. 2016. Trade-offs and synergies between provisioning and regulating ecosystem services in mountain area Portugal affected by landscape change. Mountain Research and Development 36(4): 452-464.

26. Cantiani, M. G., C. Geitner, C. Haida, F. Maino, C. Tattoni, D. Vettorato, and M. Ciolli. 2016. Balancing economic development and environmental conservation for a new governance of Alpine areas. Sustainability 8(8): 802. 
27. Langer, A., F. Irauschek, S. Perez, M. Pardos, T. Zlatanov, K. Öhman, E.-M. Nordström, and M. J. Lexer. 2017. Value-based ecosystem service trade-offs in multi-objective management in European mountain forests. Ecosystem Services 26: 245-257.

28. Cavallaro, F., F. Ciari, S. Nocero, F. Prettenthaler, and A. Scuttari. 2017. The impacts of climate change on tourist mobility in mountain areas. Journal of Sustainable Tourism 28(8): 1063-1083.

29. Portman, M. E., and E. Yargen. 2016. Ecosystem services assessment from the mountain to the sea: In search of a method for land and seascape planning. Urban Sustainability: Policy and Praxis 14: 23-41.

30. Djordjevic, D. S., V. Secerov, D Filipovic, B. Lukic, and M. R. Jeftic. 2016. The impact of climate change on the planning of mountain tourism development in Serbia: Case studies of Kopaonik and Zlatibor. Fresenius Environmental Bulletin 25(11): 5027-5034. 
Appendix 4. Records generated for specific searches. Given the limited search capability of databases, a hierarchical approach to searching was used, converting the original string to key words (e.g., "scenario") and topics (e.g., "mountain"). Searches were subject to the specific rules of individual databases; and variations were documented. Where the facilities were available, language limits to English were set. Where no search bar existed, websites were also hand-searched. The web addresses were correct in July 2020.

\begin{tabular}{|c|c|c|c|c|c|c|c|c|c|}
\hline Source & Database & Results & $\begin{array}{c}\text { Included } \\
\text { at title }\end{array}$ & $\begin{array}{c}\text { Included } \\
\text { at } \\
\text { abstract }\end{array}$ & $\begin{array}{c}\text { Included } \\
\text { at full } \\
\text { text }\end{array}$ & $\begin{array}{l}\text { Included } \\
\text { at critical } \\
\text { appraisal }\end{array}$ & $\begin{array}{c}\text { Date } \\
\text { downloaded }\end{array}$ & Search terms & Link \\
\hline \multirow{5}{*}{ 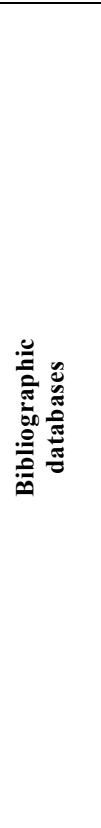 } & $\begin{array}{l}\text { Thomson } \\
\text { Reuter's } \\
\text { (formally ISI) } \\
\text { Web of } \\
\text { Science } \\
\text { Collection Core } \\
\end{array}$ & 43 & 34 & 23 & 12 & 12 & 9/5/17 & $\begin{array}{l}\text { TOPIC:("scenario analy*" OR "scenario develop*" OR } \\
\text { "scenario plan*" OR } \\
\text { "scenario") AND TOPIC: ("mountain*") AND TOPIC: (" } \\
\text { participat*" OR "collaborat*") Limiters: English } \\
\text { language, Exclude: data set, legislation, clinical trial, } \\
\text { patent, news }\end{array}$ & $\underline{\text { https://login.webofknowledge.com/ }}$ \\
\hline & $\begin{array}{l}\text { Academic } \\
\text { Search Premier }\end{array}$ & 39 & 16 & 9 & 1 & 1 & $9 / 28 / 17$ & $\begin{array}{l}\text { TOPIC:("scenario analy*" OR "scenario develop*" OR } \\
\text { "scenario plan*" OR } \\
\text { "scenario") AND TOPIC: ("mountain*") AND TOPIC: (" } \\
\text { participat*" OR "collaborat*") Limiters: Language: } \\
\text { English. Sorted by relevance. }\end{array}$ & $\begin{array}{l}\text { https://www.ebsco.com/products/research- } \\
\text { databases/academic-search-premier }\end{array}$ \\
\hline & $\begin{array}{l}\text { CAB Abstracts } \\
\text { published by } \\
\text { CAB } \\
\text { International, } \\
1973 \text { - present }\end{array}$ & 48 & 21 & 13 & 0 & 0 & 9/28/17 & $\begin{array}{l}\text { TOPIC:("scenario analy*" OR "scenario develop*" OR } \\
\text { "scenario plan*" OR } \\
\text { "scenario") AND TOPIC: ("mountain*") AND TOPIC: (" } \\
\text { participat*" OR "collaborat*") Limiters: Language: } \\
\text { English. Sorted by relevance. }\end{array}$ & $\begin{array}{l}\text { https://www.cabdirect.org } \\
\text { via } \\
\text { ovidsp.tx.ovid.com }\end{array}$ \\
\hline & $\begin{array}{l}\text { AGRICOLA } \\
\text { Agricultural } \\
\text { Research } \\
\text { Database }\end{array}$ & 8 & 1 & 1 & 1 & 1 & 9/28/17 & $\begin{array}{l}\text { TOPIC:("scenario analy*" OR "scenario develop*" OR } \\
\text { "scenario plan*" OR } \\
\text { "scenario") AND TOPIC: ("mountain*") AND TOPIC: (" } \\
\text { participat*" OR "collaborat*") Limiters: Language: } \\
\text { English. Sorted by relevance. }\end{array}$ & $\begin{array}{l}\text { https://www.ebsco.com/products/research- } \\
\text { databases/agricola }\end{array}$ \\
\hline & $\begin{array}{l}\text { Social Sciences } \\
\text { Full Text (H. } \\
\text { W. Wilson) }\end{array}$ & 3 & 1 & 1 & 0 & 0 & 9/28/17 & $\begin{array}{l}\text { TOPIC:("scenario analy*" OR "scenario develop*" OR } \\
\text { "scenario plan*" OR } \\
\text { "scenario") AND TOPIC: ("mountain*") AND TOPIC: (" } \\
\text { participat*" OR "collaborat*") Limiters: Language: } \\
\text { English. Sorted by relevance. }\end{array}$ & $\begin{array}{l}\text { https://www.ebsco.com/products/research- } \\
\text { databases/social-sciences-full-text }\end{array}$ \\
\hline \multirow{5}{*}{ 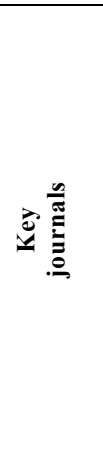 } & $\begin{array}{l}\text { Mountain } \\
\text { Research and } \\
\text { Development }\end{array}$ & 852 & 8 & 6 & 2 & 2 & $10 / 1 / 17$ & Hand searched & http://www.bioone.org/loi/mred \\
\hline & Earth's Future & 69 & 12 & 0 & 0 & 0 & $10 / 2 / 17$ & $\begin{array}{l}\text { Scenario AND mountain AND participatory (search } \\
\text { terms searched separately) }\end{array}$ & $\begin{array}{l}\text { https://agupubs.onlinelibrary.wiley.com/jour } \\
\underline{\text { nal/23284277 }}\end{array}$ \\
\hline & $\begin{array}{l}\text { Environmental } \\
\text { Modeling and } \\
\text { Software }\end{array}$ & 32 & 23 & 8 & 1 & 1 & $10 / 2 / 17$ & $\begin{array}{l}\text { scenario* AND mountain* AND participatory, sorted by } \\
\text { relevance }\end{array}$ & $\begin{array}{l}\text { https://www.journals.elsevier.com/en } \\
\text { vironmental-modelling-and-software }\end{array}$ \\
\hline & \multirow{2}{*}{$\begin{array}{l}\text { Ecology and } \\
\text { Society }\end{array}$} & 37 & 29 & 15 & 1 & 1 & $10 / 15 / 17$ & $\begin{array}{l}\text { "participatory scenario" [Select: search article topic; } \\
\text { match all of these words] }\end{array}$ & \multirow{2}{*}{ https://www.ecologyandsociety.org } \\
\hline & & 10 & 8 & 4 & 1 & 1 & $10 / 15 / 17$ & $\begin{array}{l}\text { Special issue on Landscape Scenarios and } \\
\text { Multifunctionality: Making Land Use Impact Assessment } \\
\text { Operational }\end{array}$ & \\
\hline 宽 & $\begin{array}{l}\text { Mountain } \\
\text { Sentinels } \\
\text { Collaborative } \\
\text { Network }\end{array}$ & 21 & 15 & 15 & 10 & 10 & $4 / 22 / 17$ & Open call & Not applicable \\
\hline
\end{tabular}




\begin{tabular}{|c|c|c|c|c|c|c|c|c|c|}
\hline Source & Database & Results & $\begin{array}{l}\text { Included } \\
\text { at title }\end{array}$ & $\begin{array}{l}\text { Included } \\
\text { at } \\
\text { abstract }\end{array}$ & $\begin{array}{l}\text { Included at } \\
\text { full text }\end{array}$ & $\begin{array}{l}\text { Included at } \\
\text { critical } \\
\text { appraisal }\end{array}$ & $\begin{array}{c}\text { Date } \\
\text { downloaded }\end{array}$ & Search terms & Link \\
\hline \multirow{14}{*}{ 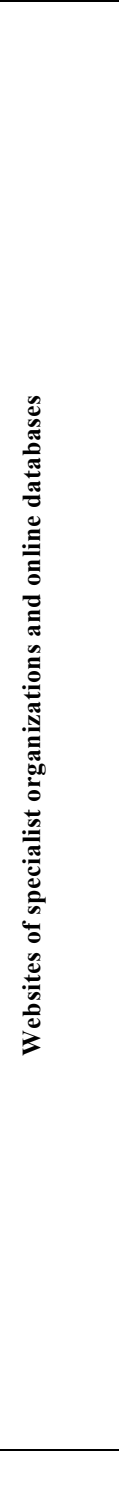 } & $\begin{array}{l}\text { The Mountain } \\
\text { Institute (TMI) }\end{array}$ & 10 & 8 & 3 & 0 & 0 & $10 / 9 / 17$ & $\begin{array}{l}\text { About us tab -> publications }->\text { search in English under } \\
\text { Glaciers, Himalayan Program and Andes Program }\end{array}$ & http://mountain.org/publications/ \\
\hline & $\begin{array}{l}\text { Mountain } \\
\text { Research } \\
\text { Initiative (MRI) }\end{array}$ & 15 & 14 & 0 & 0 & 0 & $10 / 9 / 17$ & resources tab -> publications & $\begin{array}{l}\text { https://www.mountainresearchinitiative.org/ } \\
\text { resources-opportunities }\end{array}$ \\
\hline & $\begin{array}{l}\text { United Nations } \\
\text { Environment } \\
\text { Program } \\
\text { (UNEP) }\end{array}$ & 13 & 11 & 8 & 0 & 0 & $10 / 10 / 17$ & $\begin{array}{l}\text { UNEP Knowledge Repository - > Publications Search -> } \\
\text { scenario, mountain. Filter by English }\end{array}$ & http://www.unep.org/publications/ \\
\hline & $\begin{array}{l}\text { Interdisciplinary } \\
\text { Mountain } \\
\text { Research }\end{array}$ & 19 & 2 & 0 & 0 & 0 & $10 / 10 / 17$ & $\begin{array}{l}\text { Search: scenario* OR participat*. All words, Articles. } \\
\text { Searched articles within projects retrieved from search. }\end{array}$ & $\underline{\text { http://www.mountainresearch.at/index.php/e }}$ \\
\hline & $\begin{array}{l}\text { International } \\
\text { Centre for } \\
\text { Integrated } \\
\text { Mountain } \\
\text { Development } \\
\text { (ICIMOD) } \\
\end{array}$ & 14 & 9 & 3 & 0 & 0 & 9/28/17 & $\begin{array}{l}\text { "scenario analy*" OR "scenario develop*" OR "scenario } \\
\text { plan*" OR "scenario" AND "mountain*" AND } \\
\text { "participat*" OR "collaborat*" }\end{array}$ & https://lib.icimod.org \\
\hline & $\begin{array}{l}\text { Stockholm } \\
\text { Resilience } \\
\text { Centre }\end{array}$ & 59 & 20 & 10 & 2 & 2 & $10 / 11 / 17$ & Mountain + socio-ecological + scenario & $\begin{array}{l}\text { http://www.stockholmresilience.org/publicat } \\
\text { ions.html }\end{array}$ \\
\hline & $\begin{array}{l}\text { Social- } \\
\text { Ecological } \\
\text { Systems (SES) } \\
\text { Library }\end{array}$ & 14 & 11 & 2 & 0 & 0 & $10 / 11 / 17$ & Quick start: "scenario" & $\underline{\text { https://seslibrary.asu.edu/ }}$ \\
\hline & $\begin{array}{l}\text { International } \\
\text { Commission for } \\
\text { the Protection } \\
\text { of the Alps } \\
\text { (CIPRA) }\end{array}$ & 100 & 25 & 6 & 0 & 0 & $10 / 11 / 17$ & Hand searched first 100 articles & $\underline{\text { http://www.cipra.org/en/publications }}$ \\
\hline & $\begin{array}{l}\text { EURAC } \\
\text { Research }\end{array}$ & 48 & 15 & 8 & 2 & 2 & $10 / 11 / 17$ & Institute: All; Keyword: mountain, scenario & $\begin{array}{l}\text { http://www.eurac.edu/en/research/Publication } \\
\text { s/Pages/default.aspx }\end{array}$ \\
\hline & $\begin{array}{l}\text { Ecosystem } \\
\text { Services and } \\
\text { Poverty } \\
\text { Alleviation }\end{array}$ & 280 & 21 & 6 & 0 & 0 & $10 / 23 / 17$ & $\begin{array}{l}\text { Search: "scenario". Included only articles screened at } \\
\text { Abstract stage. }\end{array}$ & $\underline{\text { http://www.espa.ac.uk/ }}$ \\
\hline & Valuing Arc & 2 & 1 & 1 & 0 & 0 & $11 / 8 / 17$ & Hand searched & $\begin{array}{l}\text { http://www.valuingthearc.org } \\
\text { currently } \\
\text { https://eprints.soton.ac.uk/372347/1/VtAspecia } \\
\text { lissue.pdf }\end{array}$ \\
\hline & $\begin{array}{l}\text { The Mountain } \\
\text { Partnership of } \\
\text { the UNFAO }\end{array}$ & 29 & 23 & 6 & 0 & 0 & $10 / 13 / 17$ & $\begin{array}{l}\text { Publications tab -> Mountain Partnership Key } \\
\text { Publications, Member publications }\end{array}$ & $\begin{array}{l}\text { http://www.fao.org/mountain- } \\
\text { partnership/publications/en/ }\end{array}$ \\
\hline & $\begin{array}{l}\text { Natural Capital } \\
\text { Project }\end{array}$ & 18 & 11 & 5 & 1 & 0 & $11 / 8 / 17$ & $\begin{array}{l}\text { Publication library -> Search: "scenario", "mountain", All } \\
\text { Publications }\end{array}$ & $\begin{array}{l}\text { https://naturalcapitalproject.stanford.edu/pub } \\
\text { lications }\end{array}$ \\
\hline & $\begin{array}{l}\text { Mountain } \\
\text { Sentinels }\end{array}$ & 6 & 6 & 0 & 0 & 0 & $11 / 8 / 17$ & $\begin{array}{l}\text { Publication library -> Search: "scenario", "mountain", All } \\
\text { Publications }\end{array}$ & https://mountainsentinels.org/ \\
\hline 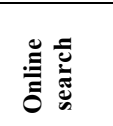 & Google Scholar & 200 & 133 & 45 & 10 & 9 & 9/27/17 & $\begin{array}{l}\text { Advanced search with results organized by relevance: } \\
\text { scenario, mountain, participate*, social-ecological. } \\
\text { Limiters: Exclude patents, exclude citations. Sorted by } \\
\text { relevance. Searched first } 200 \text { results out of } 4330 .\end{array}$ & https://scholar.google.com/ \\
\hline TOTAL & & 1989 & 479 & 198 & 44 & 42 & & & \\
\hline
\end{tabular}


Appendix 5. Master database

Please click here to download file 'appendix 5.xlsx'. 
Ecology and Society 25(3): 6

https://www.ecologyandsociety.org/vol25/iss3/art6/

Appendix 6. Codebook

Please click here to download file 'appendix6.xlsx'. 
Appendix 7. List of case studies analyzed. NTFP: Non-timber forest products. Land use categories are based on Klein et al.

$2019 \mathrm{~b}$.

\begin{tabular}{|c|c|c|c|c|c|c|}
\hline No. & Location & Primary economic activity (s) & Primary land use (s) & $\begin{array}{l}\text { Baseline } \\
\text { year }\end{array}$ & $\begin{array}{l}\text { Target } \\
\text { year }\end{array}$ & Reference \\
\hline 1 & $\begin{array}{l}\text { Norway, France, Switzerland, Belgium, } \\
\text { Germany, Austria, Portugal, Spain, } \\
\text { Balkans, Turkey, Greece, Ukraine, } \\
\text { Czech Republic, Poland, UK, Ireland: } \\
\text { Alps, Carpathian Mountains, Apennines, } \\
\text { Pyrenees, } \\
\text { Iberian mountains, Nordic mountains, } \\
\text { The Caucasus }\end{array}$ & Service sector (trade and tourism), Agricultural & $\begin{array}{l}\text { Crops, Agropastoral, } \\
\text { Tourism/recreation }\end{array}$ & 2005 & 2050 & Sarkki et al. 2017 \\
\hline 2 & $\begin{array}{l}\text { Romania: Iezer Mountains of the } \\
\text { Southern Carpathians }\end{array}$ & Forestry & Timber/logging & 2012 & $\begin{array}{l}\text { Unspec } \\
\text { ified }\end{array}$ & Bogdan et al. 2016 \\
\hline 3 & Italy: Carnian and Julian Alps & $\begin{array}{l}\text { Private sector or resources industries, Service } \\
\text { sector (trade and tourism) }\end{array}$ & Agropastoral & 2013 & 2035 & Malek and Boerboom 2015 \\
\hline 4 & France: Central French Alps & Service sector (trade and tourism), Agricultural & Pastoral, Agropastoral & 2003 & 2050 & Lamarque et al. 2013 \\
\hline 5 & UK: Peak District & Agriculture, Tourism, Hunting & Agropastoral, Tourism & 2009 & 2030 & Reed et al. 2013 \\
\hline 6 & $\begin{array}{l}\text { Slovakia: Carpathian Mountains, } \\
\text { Slovensky Raj National Park }\end{array}$ & Tourism, Forestry & Timber/logging, Tourism & 2006 & 2030 & Bizikova et al. 2012 \\
\hline 7 & France: Pic Saint-Loup Mountain & Pastoral & Pastoral & 2008 & 2040 & Griffo et al. 2011 \\
\hline 8 & Greece: Pindos Mountains & Service sector (trade and tourism), Agricultural & Agropastoral, Tourism & 2010 & 2035 & Tzanopoulos et al. 2011 \\
\hline 9 & Nepal: Himalayas & Service sector (trade and tourism), Agricultural & Tourism/recreation & 2007 & 2032 & Daconto and Sherpa 2010 \\
\hline 10 & Switzerland: Oberhalbstein Alps & Service sector (trade and tourism), Agricultural & $\begin{array}{l}\text { Crops, Agropastoral, } \\
\text { Tourism/recreation, Residential }\end{array}$ & 2005 & 2030 & Soliva and Hunziker 2009 \\
\hline 11 & $\begin{array}{l}\text { Cairngorms (Scotland), Causse Mejan } \\
\text { (France), Eastern Jotunheimen } \\
\text { (Norway), Surses valley (Switzerland), } \\
\text { Zagori (Greece), } \\
\text { Poloniny National Park (Slovakia) }\end{array}$ & $\begin{array}{l}\text { Private sector or resources industries, Service } \\
\text { sector (trade and tourism), Agricultural, } \\
\text { administration }\end{array}$ & $\begin{array}{l}\text { NTFPs and crops, } \\
\text { Timber/logging, Tourism }\end{array}$ & 2003 & 2060 & Soliva et al. 2008 \\
\hline 12 & Switzerland: Swiss Alps & Service sector (trade and tourism), Agricultural & Crops, Tourism/recreation & 2000 & 2050 & Walz et al. 2007 \\
\hline 13 & Thailand: Doi Tung Mountains & Subsistence economy & Crops & 2002 & 2007 & Barnaud et al. 2007 \\
\hline 14 & $\begin{array}{l}\text { Spain: Basque mountains/Pyrenees } \\
\text { mountain range }\end{array}$ & $\begin{array}{l}\text { Service sector (trade and tourism), } \\
\text { Subsistence economy }\end{array}$ & $\begin{array}{l}\text { NTFPs, Timber/Logging, } \\
\text { Tourism/ recreation, }\end{array}$ & 2015 & 2050 & Palacios-Agundez et al. 2015 \\
\hline 15 & Sweden: Fennoscandian Mountains & Private sector or resources industries & Timber/logging, Recreation & 2014 & 2044 & Carlsson et al. 2015 \\
\hline 16 & Spain: Montes Universales & Agricultural & Pastoral & 2010 & 2030 & Oteros-Rozas et al. 2013 \\
\hline 17 & USA: Rocky Mountains & Service sector & $\begin{array}{l}\text { Tourism/recreation, } \\
\text { Timber/logging }\end{array}$ & 2010 & 2030 & Wyborn et al. 2015 \\
\hline 18 & Germany: Swabian Alb & $\begin{array}{l}\text { Private sector or resources industries, Service sector } \\
\text { (trade and tourism) }\end{array}$ & Agropastoral & 2011 & 2040 & Plieninger et al. 2013 \\
\hline 19 & Portugal: Peneda-Gerès & Private sector or resources industries & Timber/Logging, Tourism & 2008 & 2050 & Carvalho-Ribeiro et al. 2010 \\
\hline 20 & Austria: Tyrolean Alps & Service sector (trade and tourism), Agricultural & Pastoral, Tourism/recreation & 2015 & 2050 & Kohler et al. 2017 \\
\hline 21 & USA: Rocky Mountains & $\begin{array}{l}\text { Service sector (trade and tourism), } \\
\text { Agricultural, Subsistence economy }\end{array}$ & $\begin{array}{l}\text { Pastoral, Timber/Logging, } \\
\text { Tourism/ recreation }\end{array}$ & 2015 & 2035 & Murphy et al. 2016 \\
\hline
\end{tabular}




\begin{tabular}{|c|c|c|c|c|c|c|}
\hline 22 & Australian Alps & $\begin{array}{l}\text { Private sector or resources industries, Service sector } \\
\text { (trade and tourism) }\end{array}$ & $\begin{array}{l}\text { Pastoral, Timber/Logging and } \\
\text { Tourism/ recreation }\end{array}$ & 2013 & 2030 & Mitchell et al. 2015 \\
\hline 23 & China: Liupan Mountains & Subsistence economy & Crops & 2005 & 2020 & Zhen et al. 2014 \\
\hline 24 & $\begin{array}{l}\text { LAO PDR: Luang Prabang Mountain } \\
\text { Range }\end{array}$ & Service sector (trade and tourism), Agricultural & NTFPs and crops, Pastoral & 2010 & NA & Bourgoin and Castella 2011 \\
\hline 25 & $\begin{array}{l}\text { Thailand, Vietnam, China, Cambodia, } \\
\text { Laos, Malaysia, Myanmar }\end{array}$ & $\begin{array}{l}\text { Service sector (trade and tourism), Agricultural, } \\
\text { Subsistence economy }\end{array}$ & $\begin{array}{l}\text { Agropastoral, Timber/Logging, } \\
\text { Tourism }\end{array}$ & 2000 & 2050 & Lebel 2006 \\
\hline 26 & France: Massif Central Range & Private sector or resources industries, Agricultural & Agropastoral & 2003 & 2023 & Simon and Etienne 2010 \\
\hline 27 & $\begin{array}{l}\text { Hindu-Kush Himalayan region (India, } \\
\text { Pakistan, Afghanistan, Nepal, Bhutan, } \\
\text { China, Myanmar) }\end{array}$ & $\begin{array}{l}\text { Semi-subsistence agricultural economy, Private } \\
\text { sector or resources industries, Service sector (trade } \\
\text { and tourism) }\end{array}$ & $\begin{array}{l}\text { NTFPs and crops, Pastoral, } \\
\text { Agropastoral }\end{array}$ & 2015 & 2080 & Roy et al. 2019 \\
\hline 28 & $\begin{array}{l}\text { Tanzania: Eastern Arc/ Rift } \\
\text { Mountains }\end{array}$ & $\begin{array}{l}\text { Semi-subsistence agricultural economy, Reduced } \\
\text { Emissions from Deforestation and Degradation } \\
\text { (REDD+), illegal timber harvesting, or mineral } \\
\text { extraction, large scale investors }\end{array}$ & Agropastoral & 2010 & 2045 & Capitani et al. 2016 \\
\hline 29 & Tanzania: Rufugi Basin & Smallholder agriculture & Agropastoral, NTFPs & 2010 & 2060 & UDSM IRA et al. 2016 \\
\hline 30 & Mongolian Plateau & $\begin{array}{l}\text { Communal pastoralism, mining, industrial sector, } \\
\text { agricultural livelihoods }\end{array}$ & Pastoral & 2014 & 2050 & Allington et al. 2018 \\
\hline 31 & Switzerland: Pennine Alps & Service sector (trade and tourism) & $\begin{array}{l}\text { Tourism, Timber/ logging, Crops, } \\
\text { Residential }\end{array}$ & 2010 & 2050 & Brand et al. 2013 \\
\hline 32 & $\begin{array}{l}\text { Switzerland: Swiss Alps and Jura } \\
\text { Mountain Range }\end{array}$ & Service sector (trade and tourism) & $\begin{array}{l}\text { Crops, Agropastoral, } \\
\text { Tourism/recreation, Residential }\end{array}$ & 2010 & 2050 & Walz et al. 2014 \\
\hline 33 & $\begin{array}{l}\text { South Africa: Ukhahlamba } \\
\text { Drakensberg (Upper Thukela) }\end{array}$ & $\begin{array}{l}\text { Agricultural, Subsistence economy, Large scale } \\
\text { commercial and smallholder farming }\end{array}$ & Crops, Agropastoral & 2010 & 2030 & Malinga et al. 2013 \\
\hline 34 & $\begin{array}{l}\text { Tanzania: South Pare Mountains, } \\
\text { Eastern Arc Mountains }\end{array}$ & Subsistence economy & Cropland & 2005 & 2030 & Enfors et al. 2008 \\
\hline 35 & $\begin{array}{l}\text { Cairngorms Mountain Range } \\
\text { (Scotland), Stubai Alps (Austria), } \\
\text { Mountain Alinyà (Spain, } \\
\text { Northeastern) Bavarian Alps } \\
\text { (Germany), Trentino Mountains } \\
\text { (Italy), Glarus Alps (Switzerland), } \\
\text { Polana Mountain Range (Slovakia) } \\
\text { Nové Hrady Mountains (Czech } \\
\text { Republic) }\end{array}$ & $\begin{array}{l}\text { Private sector or resources industries, Service sector } \\
\text { (trade and tourism), Agricultural }\end{array}$ & $\begin{array}{l}\text { NTFPs, Agropastoral, Timber/ } \\
\text { logging, Tourism/recreation }\end{array}$ & 2006 & 2026 & Bayfield et al. 2008 \\
\hline 36 & Austria: Stubai Alps & Agriculture, Tourism & Agropastoral, Tourism/recreation & 2003 & 2020 & Tappeiner et al. 2008 \\
\hline 37 & USA: Adirondack & Private sector or resources industries & Timber/ logging, Residential & 2014 & 2050 & McBride et al. 2017 \\
\hline 38 & Austrian Alps & $\begin{array}{l}\text { Private sector or resources industries, Service sector } \\
\text { (trade and tourism) }\end{array}$ & $\begin{array}{l}\text { Timber/ logging, Tourism/ } \\
\text { recreation }\end{array}$ & 2009 & 2030 & Loibl and Walz 2010 \\
\hline 39 & Mongolian Plateau & $\begin{array}{l}\text { Communal pastoralism, mining, industrial sector, } \\
\text { Agricultural }\end{array}$ & Pastoral & 2014 & 2050 & Allington et al. 2018 \\
\hline 40 & Australian Alps & $\begin{array}{l}\text { Private sector or resources industries, Service sector } \\
\text { (trade and tourism) }\end{array}$ & Pastoral, Tourism/ recreation & 2013 & 2030 & Mitchell et al. 2015 \\
\hline 41 & USA: Cascades & Private sector or resources industries, Agricultural & Agropastoral, Residential & 2010 & 2100 & Jaeger et al. 2017 \\
\hline 42 & Tanzania: Eastern Arc Mountains & Private sector or resources industries, Agricultural & $\begin{array}{l}\text { NTFP, Agropastoral, } \\
\text { Agroforestry, Timber/ logging }\end{array}$ & 2011 & 2025 & Fisher et al. 2011 \\
\hline
\end{tabular}




\section{Appendix 8. Studies included in the systematic review.}

Allington, G. R. H., M. Fernández-Giménez, J. Chen, and D. G. Brown. 2018. Combining participatory scenario planning and systems modeling to identify drivers of future sustainability on the Mongolian Plateau. Ecology and Society 23: 9.

Barnaud, C., T. Promburom, G. Trebuil, and F. Bousquet. 2007. An evolving simulation and gaming process to facilitate adaptive watershed management. Simulation and Gaming 38: $398-420$.

Bayfield, N., P. Barancok, M. Furger, M. T. Sebastià, G. Domínguez, M. Lapka, E.

Cudlinova, L. Vescovo, D. Ganielle, A. Cernusca, U. Tappeiner, and M. Drösler. 2008. Stakeholder perceptions of the impacts of rural funding scenarios on mountain landscapes across Europe. Ecosystems 11: 1368-1382.

Bizikova, L., M. Nijnik, and T. Kluvanková-Oravská. 2012. Sustaining multifunctional forestry through the developing of social capital and promoting participation: A case of multiethnic mountain communities. Small-scale Forestry 11:301-319.

Bogdan, S.-M., I. Pătru-Stupariu, and L. Zaharia. 2016. The assessment of regulatory ecosystem services: the case of the sediment retention service in a mountain landscape in the Southern Romanian Carpathians. Procedia Environmental Sciences 32: $12-27$.

Bourgoin, J., and J-C. Castella. 2011. "PLUP FICTION": Landscape simulation for 
participatory land use planning in Northern Lao PDR. Mountain Research and Development 31: 78-88.

Brand, F. S., R. Seidl, Q. B. Le, J. M. Brändle, and R. W. Scholz. 2013. Constructing consistent multiscale scenarios by transdisciplinary processes: the case of mountain regions facing global change. Ecology and Society 18: 43.

Capitani, C., K. Mukama, B. Mbilinyi, I. Malugu, K. T. Munishi, N. D. Burgess, P. J. Platts, S. Sallu, and R. Marchant. 2016. From local scenarios to national maps: a participatory framework for envisioning the future of Tanzania. Ecology and Society 21: 5 .

Carlsson, J., L. O. Eriksson, K. Öhman, and E.-M.Nordström. 2015. Combining scientific and stakeholder knowledge in future scenario development - A forest landscape case study in northern Sweden. Forest Policy and Economics 61(Supplement C): 122-134.

Carvalho-Ribeiro, S. M., A. Lovett, and T. O'Riordan. 2010. Multifunctional forest management in Northern Portugal: Moving from scenarios to governance for sustainable development. Land Use Policy 27: 1111-1122.

Daconto, G., and L. N. Sherpa. 2015. Applying scenario planning to park and tourism management in Sagarmatha National Park, Khumbu, Nepal. Mountain Research and Developmen, 30: 103-112.

Enfors, E. I., L. J. Gordon, L. J., G. D. Peterson, and D. Bossio. 2008. Making investments 
in dryland development work: participatory scenario planning in the Makanya catchment, Tanzania. Ecology and Society 13: 42.

Fisher, B., R. K. Turner, N. D. Burgess, R. D. Swetnam, J. Green, R. E. Green, G. Kajembe, K. S. Kulindwa, L. Lewis, R. Marchant, S. Marshall, A. R. Madoffe, P. K. Munishi, S. Morse-Jones, S. Mwakalila, J. Paavola, R. Naidoo, T. Ricketts, M. Rouget, , S. Willcock, S. White, and A. Balmford. 2011. Measuring, modeling and mapping ecosystem services in the Eastern Arc Mountains of Tanzania. Progress in Physical Geography 35: 595-611.

Griffon, S., A. Nespoulous, J-P. Cheylan, P. Marty, and D. Auclair. 2011. Virtual reality for cultural landscape visualization. Virtual Reality 15: 279-294.

Jaeger, W. K., A. Amos, D. P. Bigelow, H. Chang, D. R., Conklin, R. Haggerty, C. Langpap, K. Moore, P. W. Mote, A.W. Nolin, A. J. Plantinga, C. L. Schwartz, D. Tullos, and D. P. Turner. 2017. Finding water scarcity amid abundance using human-natural system models. Proceedings of the National Academy of Sciences114: 11884-11889.

Kohler, M., R. Stotten, M. Steinbacher, G. Leitinger, E. Tasser, U. Schirpke, U. Tappeiner, and M. Schermer. 2017. Participative spatial scenario analysis for Alpine ecosystems. Environmental Management 60: 679-692.

Lamarque, P., Artaux, A., Barnaud, C., Dobremez, L., Nettier, B., and Lavorel, S. 2013. Taking into account farmers' decision making to map fine-scale land management 
adaptation to climate and socio-economic scenarios. Landscape and Urban Planning, 119 (Supplement C): 147-157.

Lebel, L. 2006. Multi-level scenarios for exploring alternative futures for upper tributary watersheds in mainland Southeast Asia. Mountain Research and Development 26: 263-273.

Loibl, W., and A. Walz. 2010. Generic regional development strategies from local stakeholders' scenarios - the Montafon experience. Ecology and Society 15: 5.

Malek, Z., and L. Boerboom, L. 2015. Participatory scenario development to address potential impacts of land use change: An example from the Italian Alps. Mountain Research and Development 35: 126-138.

Malinga, R., L. J. Gordon, R. Lindborg, and G. Jewitt. 2013. Using participatory scenario planning to identify ecosystem services in changing landscapes. Ecology and Society 18: 10 .

McBride, M. F., E. Lambert, S. Huff, K. A. Theoharides, P. Field, and J. R. Thompson. 2017. Increasing the effectiveness of participatory scenario development through codesign. Ecology and Society, 22: 16.

Mitchell, M., M. Lockwood, S. A. Moore, and S. Clement. 2015. Scenario analysis for biodiversity conservation: A social-ecological system approach in the Australian Alps. Journal of Environmental Management 150 (Supplement C): 69-80. 
Mitchell, M., M. Lockwood, S. A. Moore, S. Clement, S. Gilfedder, and G. Anderson. 2016. Using scenario planning to assess governance reforms for enhancing biodiversity outcomes. Land Use Policy 50: 559-572.

Murphy, D., C. Wyborn, L. Yung, D. R. Williams, C. Cleveland, S. Eby, L. Dobrowski, and E. Towler. 2016. Engaging communities and climate change futures with multi-scale, iterative scenario building (MISB) in the Western United States. Human Organization 75:1.

Oteros-Rozas, E., B. Martín-López, C. López, A. I. Palomo, and J. A. González. 2013. Envisioning the future of transhumant pastoralism through participatory scenario planning: a case study in Spain. The Rangeland Journal: 22.

Palacios-Agundez, I., M. Onaindia, M. Potschin, J. A. Tratalos, I. Madariaga, and R. HainesYoung, R. 2015. Relevance for decision making of spatially explicit, participatory scenarios for ecosystem services in an area of a high current demand. Environmental Science and Policy 54 (Supplement C): 199-209.

Plieninger, T., C. Bieling, B. Ohnesorge, H. Schaich, C. Schleyer, and F. Wolff. 2013. Exploring futures of ecosystem services in cultural landscapes through participatory scenario development in the Swabian Alb, Germany. Ecology and Society 18: 39.

Reed, M.S., K. Hubacek, A. Bonn, T. P. Burt, J. Holden, L. C. Stringer, N. Beharry- Borg, S. Buckmaster, D. Chapman, P. J. Chapman, G. D. Clay, S. J. Cornell, A. J. Dougill, 

A. C. Evely, E. D. G. Fraser, N. Jin, B. J. Irvine, M. J. Kirkby, W. E. Kunin, C. Prell, C. H. Quinn, B. Slee, S. Stagl, M. Termansen, S. Thorp, and F. Worrall. 2013. Anticipating and managing future trade-offs and complementarities between ecosystem services. Ecology and Society 18: 5-18.

Roy, J., E. Moors, M. S. R. Murthy, S. V. R. K. Prabhakar, B. N. Khattak, P. Shi, C. Huggel, and V. Chitale. 2019. Exploring futures of the Hindu Kush Himalaya: Scenarios and pathways. In: Wester P., Mishra A., Mukherji A., Shrestha A. (eds) The Hindu Kush Himalaya Assessment. Springer, Cham.

Sarkki, S., A. Ficko, K. Grunewald, A. P. Kyriazopoulos, and M. Nijnik. 2017. How pragmatism in environmental science and policy can undermine sustainability transformations: the case of marginalized mountain areas under climate and land- use change. Sustainability Science 12: 549-561.

Simon, C., and M. Etienn. 2010. A companion modeling approach applied to forest management planning. Environmental Modeling and Software 25: 1371-1384.

Soliva, R., and M. Hunziker. 2009. Beyond the visual dimension: Using ideal type narratives to analyse people's assessments of landscape scenarios. Land Use Policy 26: 284294.

Soliva, R., K. Rønningen, I. Bella, P. Bezak, T. Cooper, B. E. Flø, P. Marty, and C. Potter. 2008. Envisioning upland futures: Stakeholder responses to scenarios for Europe's mountain landscapes. Journal of Rural Studies 24: 56-71. 
Tappeiner, U., E. Tasser, G. Leitinger, A. Cernusca, and G. Tappeiner. 2008. Effects of historical and likely future scenarios of land use on above- and belowground vegetation carbon stocks of an Alpine Valley. Ecosystems 11: 1383-1400.

Tzanopoulos, J., A. S. Kallimanis, I. Bella, L. Labrianidis, S. Sgardelis, J. D. Pantis, 2011. Agricultural decline and sustainable development on mountain areas in Greece: Sustainability assessment of future scenarios. Land Use Policy 28: 585- 593.

USAID 2016. Scenario analysis report. Dar Es Salaam, Tanzania University of Dar Es Salaam Institute of Resource Assessment: Tanzania.

Walz, A., J. M. Braendle, D. J. Lang, F. Brand, S. Briner, C. Elkin, C. Hirschi, R. Huber, H. Lischke, and D. R. Schmatz. 2014. Experience from downscaling IPCC- SRES scenarios to specific national-level focus scenarios for ecosystem service management. Technological Forecasting and Social Change 86(Supplement C): 21-32.

Walz, A., C. Lardelli, H. Behrendt, A. Gret-Regamey, C. Lundstrom, S. Kytzia, and P. Bebi. 2007. Participatory scenario analysis for integrated regional modeling. Landscape and Urban Planning 81: 114-131.

Wyborn, C., L. Yung, D. Murphy, and D. R. Williams. 2015. Situating adaptation: How governance challenges and perceptions of uncertainty influence adaptation in the Rocky Mountains. Regional Environmental Change 15: 669-682. 
Zhen, L., X. Deng, Y. Wei, Q. Jiang, Y. Lin, K. Helming, C. Wang, H. J. König, and J. Hu. 2014. Future land use and food security scenarios for the Guyuan district of remote western China. iForest 7:372-384 
Appendix 9. Results from coded variables

0. Bibliographic coverage Publication type

$\begin{array}{rll} & \text { No. } & \text { \% of case studies } \\ \text { Journals } & 40 & 95.2 \\ \text { Reports } & 1 & 2.4 \\ \text { Unpublished manuscripts } & 1 & 2.4\end{array}$

Publication or journal title

\section{Publisher}

$\begin{array}{rll}\text { Resilience Alliance } & 9 & 21.4 \\ \text { Elsevier Sci Ltd } & 7 & 16.7 \\ \text { Springer } & 5 & 11.9 \\ \text { International Mountain Society } & 4 & 9.5 \\ \text { Elsevier Sci BV } & 4 & 9.5 \\ \text { Sage Publications } & 1 & 2.4 \\ \text { Sage Publications Inc. } & 1 & 2.4 \\ \text { Science Direct } & 1 & 2.4 \\ \text { SISEF-Italian Society of Silviculture and Forest Ecology } & 1 & 2.4 \\ \text { Society for Applied Anthropology } & 1 & 2.4 \\ \text { ICIMOD } & 1 & 2.4\end{array}$




$\begin{array}{rcc}\text { Springer Japan KK } & 1 & 2.4 \\ \text { Springer London-Ltd } & 1 & 2.4 \\ \text { CSIRO } & 1 & 2.4 \\ \text { USAID } & 1 & 2.4 \\ \text { National Academy of Sciences } & 1 & 2.4 \\ \text { Pergamon-Elsevier Science Ltd } & 1 & 2.4\end{array}$

Open access journal articles

$$
\begin{array}{rrr}
\text { No } & 23 & 57.5 \\
\text { Yes } & 17 & 42.5
\end{array}
$$

\section{Initial assessment}

Scenario purpose

$\begin{array}{rll}\text { Understanding } & 33 & 78.57 \\ \text { Decision support } & 19 & 45.24 \\ \text { Prediction } & 13 & 30.95 \\ \text { Learning } & 5 & 11.9 \\ \text { Communication } & 4 & 9.5\end{array}$

Goal

$\begin{array}{rll}\text { Exploratory } & 25 & 59.5 \\ \text { Pre-policy } & 10 & 23.8 \\ \text { Both } & 6 & 14.3 \\ \text { Not stated } & 1 & 2.4\end{array}$

Function

$\begin{array}{rll}\text { Process } & 20 & 47.6 \\ \text { Both } & 13 & 31.0 \\ \text { Product } & 9 & 21.4\end{array}$

Method(s) of initial assessment

$\begin{array}{lll}\text { Building on long-term research collaborations } & 18 & 42.9\end{array}$

Key stakeholder interviews $17 \quad 40.5$

$\begin{array}{lll}\text { Literature review } & 8 & 19.0\end{array}$

$\begin{array}{lll}\text { Focus groups } 6 & 6\end{array}$

Workshops $3 \quad 7.1$

Field visits $1 \quad 2.4$

Information given to participants beforehand

$\begin{array}{rll}\text { Not stated } & 22 & 52.4 \\ \text { Yes } & 18 & 42.9 \\ \text { No } & 2 & 4.8\end{array}$

2. Define system boundaries

Publication year

$\begin{array}{lll}2017 \quad 6 & 14.3\end{array}$ 


$\begin{array}{lll}2016 & 5 & 11.9 \\ 2015 & 7 & 16.7 \\ 2014 & 1 & 2.4 \\ 2013 & 6 & 14.3 \\ 2012 & 1 & 2.4 \\ 2011 & 4 & 9.5 \\ 2010 & 4 & 9.5 \\ 2009 & 1 & 2.4 \\ 2008 & 4 & 9.5 \\ 2007 & 2 & 4.8 \\ 2006 & 1 & 2.4\end{array}$

\section{Baseline year}

$\begin{array}{rll}2015 & 4 & 9.5 \\ 2014 & 4 & 9.5 \\ 2013 & 3 & 7.1 \\ 2012 & 1 & 2.4 \\ 2011 & 2 & 4.8 \\ 2010 & 9 & 21.4 \\ 2009 & 2 & 4.8 \\ 2008 & 2 & 4.8 \\ 2007 & 1 & 2.4 \\ 2006 & 2 & 4.8 \\ 2005 & 4 & 9.5 \\ 2003 & 4 & 9.5 \\ 2000 & 2 & 4.8 \\ \text { Not stated } & 2 & 4.8\end{array}$

Midterm year

$\begin{array}{rll}2040 & 1 & 2.4 \\ 2030 & 2 & 4.8 \\ 2025 & 2 & 4.8 \\ 2015 & 1 & 2.4 \\ 2011 & 1 & 2.4 \\ 2010 & 1 & 2.4 \\ \text { Not stated } & 34 & 81.0\end{array}$

Target year

$\begin{array}{lll}2100 & 1 & 2.4 \\ 2080 & 1 & 2.4 \\ 2060 & 2 & 4.8 \\ 2050 & 12 & 28.6 \\ 2045 & 1 & 2.4 \\ 2044 & 1 & 2.4 \\ 2040 & 3 & 7.1 \\ 2035 & 3 & 7.1\end{array}$




$\begin{array}{rll}2032 & 1 & 2.9 \\ 2030 & 9 & 21.4 \\ 2026 & 1 & 2.4 \\ 2025 & 1 & 2.4 \\ 2023 & 1 & 2.4 \\ 2020 & 2 & 4.8 \\ \text { Not stated } & 3 & 7.1\end{array}$

\section{Primary region}

$\begin{array}{rll}\text { Europe } & 23 & 54.8 \\ \text { Asia } & 8 & 19.0 \\ \text { Africa } & 5 & 11.9 \\ \text { North America } & 4 & 9.5 \\ \text { Oceania } & 2 & 4.8 \\ \text { South America } & 0 & 0.0\end{array}$

Country study sites $(\mathrm{n}=127)$

$\begin{array}{rll}\text { Tanzania } & 17 & 13.4 \\ \text { Spain } & 9 & 7.1 \\ \text { Slovakia } & 7 & 5.5 \\ \text { Norway } & 6 & 4.7 \\ \text { Switzerland } & 6 & 4.7 \\ \text { Greece } & 5 & 3.9 \\ \text { Italy } & 5 & 3.9 \\ \text { UK } & 5 & 3.9 \\ \text { USA } & 5 & 3.9 \\ \text { Austria } & 4 & 3.2 \\ \text { Bulgaria } & 4 & 3.2 \\ \text { China } & 4 & 3.2 \\ \text { France } & 4 & 3.2 \\ \text { Czech Republic } & 3 & 2.4 \\ \text { Finland } & 3 & 2.4 \\ \text { Germany } & 3 & 2.4 \\ \text { Sweden } & 3 & 2.4 \\ \text { Thailand } & 3 & 2.4 \\ \text { Ukraine } & 3 & 2.4 \\ \text { Slovenia } & 2 & 1.6 \\ \text { Australia } & 2 & 1.6 \\ \text { Laos } & 2 & 1.6 \\ \text { Myanmar } & 2 & 1.6 \\ \text { Nepal } & 2 & 1.6 \\ \text { Portugal } & 2 & 1.6 \\ \text { Romania } & 2 & 1.6 \\ \text { Russia } & 2 & 1.6 \\ \text { Afghanistan } & 1 & 0.8 \\ \text { Bangladesh } & 1 & 0.8 \\ \text { Bhutan } & 1 & 0.8\end{array}$




$\begin{array}{rll}\text { Cambodia } & 1 & 0.8 \\ \text { Iceland } & 1 & 0.8 \\ \text { India } & 1 & 0.8 \\ \text { Ireland } & 1 & 0.8 \\ \text { Mongolia } & 1 & 0.8 \\ \text { Pakistan } & 1 & 0.8 \\ \text { Serbia } & 1 & 0.8 \\ \text { South Africa } & 1 & 0.8 \\ \text { Vietnam } & 1 & 0.8\end{array}$

Landscape delineated by watershed $11 \quad 26.2$

Spatial scale

$\begin{array}{rll}\text { Regional } & 9 & 21.4 \\ \text { Multi-scale } & 8 & 19.0 \\ \text { Farm, village or community } & 6 & 14.3 \\ \text { International } & 5 & 11.9 \\ \text { District } & 4 & 9.5 \\ \text { National } & 4 & 9.5 \\ \text { rial area (e.g., national park) } & 3 & 7.1\end{array}$

Define geographic boundaries

Determined by political/administrative units (e.g., district) $19 \quad 45.2$

Determined by natural features (e.g., forest, mountain) $12 \quad 28.6$

Determined by both $9 \quad 21.4$

Determined by neither - selected for research $2 \quad 4.8$

Elevation minimum (meters above sea level - m.a.s.l. defined by study or stated mountain range)

$\begin{array}{rll}2500-2999 & 1 & 2.6 \\ 2000-2499 & 1 & 2.6 \\ 1500-1999 & 3 & 7.7 \\ 1000-1499 & 4 & 10.3 \\ 500-999 & 16 & 41.0 \\ 0-499 & 14 & 35.9\end{array}$

Elevation maximum (m a.s.l.)

$\begin{array}{rll}8000-8999 & 2 & 4.4 \\ 7000-7999 & 0 & 0.0 \\ 6000-6999 & 0 & 0.0 \\ 5000-5999 & 5 & 11.1 \\ 4000-4999 & 4 & 8.9 \\ 3000-3999 & 7 & 15.6 \\ 2000-2999 & 13 & 28.9 \\ 1000-1999 & 7 & 15.6 \\ 0-999 & 7 & 15.6\end{array}$




\section{Climate}

$\begin{array}{rlr}\text { Temperate } & 22 & 52.4 \\ \text { Dry land or semi-arid } & 8 & 19.0 \\ \text { Tropical or sub-tropical } & 7 & 16.7 \\ \text { Multiple } & 6 & 14.3 \\ \text { Alpine, inner-alpine, cold continental or subarctic climate } & 5 & 11.9\end{array}$

Biome(s)

Grasslands, shrub lands, savannah $21 \quad 50.0$

Forested protected $14 \quad 33.3$

Various $12 \quad 28.6$

Forested unprotected $11 \quad 26.2$

Peri-urban or urban $5 \quad 11.9$

$\begin{array}{lll}\text { Tundra } & 3 & 7.1\end{array}$

Land use(s)

$\begin{array}{rll}\text { Tourism / recreation } & 21 & 50.0 \\ \text { Agropastoral } & 18 & 42.9 \\ \text { Timber / logging } & 14 & 33.3 \\ \text { Pastoral } & 11 & 26.2 \\ \text { Crops } & 9 & 21.4 \\ \text { Non-timber forest products } & 7 & 16.7 \\ \text { Residential (incl. business) } & 4 & 9.5\end{array}$

Main livelihood(s)

$\begin{array}{lll}\text { Small scale and commercial agriculture } & 24 & 57.1\end{array}$

$\begin{array}{lll}\text { Service sector (incl. trade and tourism) } & 23 & 54.8\end{array}$

$\begin{array}{lll}\text { Private sector or resources industries } & 21 & 50.0\end{array}$

$\begin{array}{lll}\text { Pastoralism } & 3 & 7.1\end{array}$

Administration $11 \quad 2.4$

Socio-demographic profile

$\begin{array}{rll}\text { Stated } & 34 & 81.0 \\ \text { Not stated } & 8 & 19.0\end{array}$

Main subject

$\begin{array}{rll}\text { Issue-based } & 31 & 73.8 \\ \text { Area-based } & 6 & 14.3 \\ \text { Institution-based } & 3 & 7.1 \\ \text { Institution- and area-based } & 1 & 2.4 \\ \text { Issue- and area-based } & 1 & 2.4\end{array}$

\section{Main theme}

$\begin{array}{lll}\text { Governance arrangement change, policies presses/pulses } & 42 & 100.0\end{array}$

Land use change $39 \quad 92.9$

Markets, income and employment $39 \quad 92.9$ 
Maintenance of cultural and/or biological diversity $34 \quad 81.0$

Biodiversity loss $33 \quad 78.6$

Demographic change (in/outmigration) $\quad 33 \quad 78.6$

Tourism and recreation $31 \quad 73.8$

$\begin{array}{llll}\text { Technological or infrastructure change (incl. transportation) } & 30 & 71.4\end{array}$

Climate change $\quad 28 \quad 66.7$

Freshwater use $\quad 27 \quad 64.3$

Land tenure change $\quad 23 \quad 54.8$

Food security $20 \quad 47.6$

Education $19 \quad 45.3$

Energy $\quad 18 \quad 42.9$

Timber $\quad 18 \quad 42.9$

Forage $17 \quad 40.5$

Natural hazards (incl. landslide/avalanche/floods) $\quad 17 \quad 40.5$

Fire $\quad 15 \quad 35.7$

Biological invasions and pest outbreaks $14 \quad 33.3$

$\begin{array}{llll}\text { Social equity and voice } & 11 & 26.2\end{array}$

Healthcare $\quad 10 \quad 23.8$

$\begin{array}{lll}\text { Minerals } & 8 & 19.1\end{array}$

Chemical pollution $\quad 6 \quad 14.3$

$\begin{array}{lll}\text { Glacier melt } \quad 6 & 14.3\end{array}$

Non-timber forest products $3 \quad 7.1$

Global P and N cycles 24.8

Gender equality $2 \quad 4.8$

Ocean acidification $\quad 0 \quad 0.0$

Stratospheric ozone depletion $\quad 0 \quad 0.0$

Atmospheric aerosol loading $\quad 0 \quad 0.0$

Sanitation $0 \quad 0.0$

Permafrost thaw $0 \quad 0.0$

Medicinal resources $\quad \begin{array}{ll}0 & 0.0\end{array}$

\section{Number of participants}

$\begin{array}{rll}\text { Not reported } & 14 & 33.3 \\ 120-240 & 3 & 7.1 \\ 71-80 & 3 & 7.1 \\ 61-70 & 2 & 4.8 \\ 51-60 & 3 & 7.1 \\ 41-50 & 0 & 0.0 \\ 31-40 & 1 & 2.4 \\ 21-30 & 4 & 9.5 \\ 11-20 & 11 & 26.2 \\ <10 & 0 & 0.0\end{array}$

Types of stakeholder(s)

Government offices $\quad 24 \quad 57.1$

Resource users $\quad 22 \quad 52.4$ 
Conservation groups, park authorities or NGOs $\quad 20 \quad 47.6$

Private sector $13 \quad 31.0$

Municipal councils, community or indigenous organizations $\quad 14 \quad 33.3$

Research institutes $9 \quad 21.4$

Not stated $5 \quad 11.9$

Bilateral or multilateral institutions $0 \quad 0$

Diversity of stakeholders (i.e., number of types)

$\begin{array}{rll}\text { One } & 5 & 11.9 \\ \text { Two } & 8 & 19.0 \\ \text { Three } & 10 & 23.8 \\ \text { Four } & 6 & 14.3 \\ \text { Five } & 4 & 9.5 \\ \text { Six } & 1 & 2.4 \\ \text { Seven } & 1 & 2.4 \\ \text { Eight } & 1 & 2.4 \\ \text { Nine } & 0 & 0.0 \\ \text { Ten } & 1 & 2.4 \\ \text { Not stated } & 5 & 11.9\end{array}$

Duration of stakeholder engagement

$\begin{array}{rll}>1 \text { year } & 20 & 47.6 \\ 1 \text { - 4 years } & 10 & 23.8 \\ \text { Not stated } & 9 & 21.4 \\ \text { < 1 year } & 2 & 4.8 \\ >\text { 10 years } & 1 & 2.4\end{array}$

Scenario process embedded into a larger research program

$\begin{array}{rrr}\text { Yes } & 17 & 40.5 \\ \text { Not stated } & 14 & 33.3 \\ \text { No } & 11 & 26.2\end{array}$

3. Envision futures

See forthcoming publication

4. Identify drivers of change Method(s) of data collection

Workshops $14 \quad 33.3$

In depth interviews $12 \quad 28.6$

Defined in the project scope $11 \quad 26.2$

Focus groups $9 \quad 21.4$

$\begin{array}{lll}\text { Literature review } & 7 & 16.7\end{array}$

Storylines $5 \quad 11.9$

Not stated $4 \quad 9.5$

Surveys $3 \quad 7.1$ 


$\begin{array}{rrr}\text { Field visits } & 1 & 2.4 \\ \text { Role-playing games } & 1 & 2.4 \\ \text { Land use mapping analysis } & 1 & 2.4\end{array}$

Rank drivers

$\begin{array}{rrr}\text { No } & 26 & 61.9 \\ \text { Yes } & 16 & 38.1\end{array}$

Address synergies

$\begin{array}{rrr}\text { No } & 25 & 59.5 \\ \text { Yes } & 17 & 40.5\end{array}$

Address trade-offs

$\begin{array}{rrr}\text { No } & 25 & 59.5 \\ \text { Yes } & 17 & 40.5\end{array}$

5. Construct scenario storylines

Number of scenarios created

$\begin{array}{rll}\text { Four } & 16 & 38.1 \\ \text { Three } & 13 & 31.0 \\ \text { Two } & 7 & 16.7 \\ \text { Six } & 3 & 7.1 \\ \text { One } & 2 & 4.8 \\ \text { Five } & 1 & 2.4\end{array}$

Data type

$\begin{array}{rll}\text { Both } & 20 & 47.6 \\ \text { Qualitative } & 14 & 33.3 \\ \text { Quantitative } & 7 & 16.7 \\ \text { Semi-quantitative } & 1 & 2.4\end{array}$

Forecasting or backcasting

$\begin{array}{rll}\text { Forecasting } & 38 & 90.5 \\ \text { Backcasting } & 2 & 4.8 \\ \text { Both } & 2 & 4.8\end{array}$

Method(s) of developing the scenarios

Participatory stakeholder workshops $27 \quad 64.3$

$\begin{array}{lll}\text { Desk research incl. literature review and computer simulations } & 21 & 50.0\end{array}$

Stakeholder and expert in-depth interviews $\quad 17 \quad 40.5$

Focus group discussion $10 \quad 23.8$

Building on previously existing scenarios $\quad 2 \quad 4.8$

Role-playing games $2 \quad 4.8$

Global, place-based or hybrid scenarios

Place-based scenarios $\quad 24 \quad 57.1$ 


$\begin{array}{rll}\text { Both } & 13 & 31.0 \\ \text { Global or regional scenarios } & 5 & 11.9\end{array}$

Number of workshops

$\begin{array}{rll}\text { None } & 5 & 11.9 \\ \text { One } & 11 & 26.2 \\ \text { Two } & 6 & 14.3 \\ \text { Three } & 10 & 23.8 \\ \text { Four } & 0 & 0.0 \\ \text { Five } & 2 & 4.8 \\ \text { Six } & 3 & 7.1 \\ \text { Seven } & 1 & 2.4 \\ \text { Eight } & 2 & 4.8 \\ \text { NA } & 3 & 7.1\end{array}$

\section{Quantify scenarios}

Quantify scenarios

$\begin{array}{rlr}\text { No } & 35 & 88.3 \\ \text { Yes } & 7 & 16.7\end{array}$

\section{Method of data analysis}

Semi-quantitative model (e.g., criteria cluster analysis of $17 \quad 40.5$ heterogenous rank data)

Participant surveys $12 \quad 28.6$

Geospatial Information Systems $11 \quad 26.2$

Situational and narrative analysis $4 \quad 9.5$

Qualitative coding $3 \quad 7.1$

General linear models, Markov, stepwise discriminant

$\begin{array}{rrr}\text { analysis } & 3 & 7.1 \\ \text { Multi-Agent Systems } & 2 & 4.8 \\ \text { InVEST 3.2 scenario generator } & 1 & 2.4 \\ \text { Vensim software } & 1 & 2.4 \\ \text { Network analysis } & 1 & 2.4 \\ \text { Qualitative content analysis of recorded discussions } & 1 & 2.4 \\ \text { Economic valuation } & 1 & 2.4 \\ \text { Graphical timeline } & 1 & 2.4 \\ \text { Non-parametric tests } & 1 & 2.4 \\ \text { Causal loop diagram } & 1 & 2.4\end{array}$

Inform other models

Not used for other models $\quad 23 \quad 54.8$

Agent-based models $7 \quad 16.7$

Other models $5 \quad 11.9$

Debris flow, mass balance or hydrological models $4 \quad 9.5$

Bayesian models or dynamical models $3 \quad 7.1$ 


\section{Consistency and plausibility analysis}

Test for plausibility

$$
\begin{array}{rrr}
\text { No } & 28 & 66.7 \\
\text { Yes } & 14 & 33.3
\end{array}
$$

Test for consistency

$$
\begin{array}{rlr}
\text { No } & 34 & 81.0 \\
\text { Yes } & 8 & 19.0
\end{array}
$$

Uncertainty explicitly addressed

$\begin{array}{rll}\text { Agree } & 13 & 31.0 \\ \text { Disagree } & 10 & 23.8 \\ \text { Neutral } & 7 & 16.7 \\ \text { NA } & 3 & 7.1 \\ \text { Strongly disagree } & 7 & 16.7 \\ \text { Strongly agree } & 2 & 4.8\end{array}$

8. Co-communication of PSP process and results

Dissemination

$\begin{array}{rll}\text { Yes } & 22 & 52.4 \\ \text { Not stated } & 19 & 45.2 \\ \text { No } & 1 & 2.4\end{array}$

Adaptation pathways

$$
\begin{array}{cll}
\text { Yes } & 37 & 88.1 \\
\text { No } & 5 & 11.9
\end{array}
$$

Maladaptation pathways

$$
\begin{array}{rlr}
\text { No } & 36 & 85.7 \\
\text { Yes } & 8 & 19.1
\end{array}
$$

\section{Outreach material}

$\begin{array}{rll}\text { Scientific publication } & 36 & 85.7 \\ \text { Report } & 12 & 28.6 \\ \text { Drawings / illustrations } & 8 & 19.0 \\ \text { Maps } & 7 & 16.7 \\ \text { Posters } & 3 & 7.1 \\ \text { Videos } & 2 & 4.8 \\ \text { Photographs } & 2 & 4.8 \\ \text { Recordings } & 1 & 2.4 \\ \text { Meetings } & 1 & 2.4\end{array}$

Tools

Combination of tools $17 \quad 40.5$

Knowledge representation diagrams (i.e., represent system entity, processes and interactions) $15 \quad 35.7$ 
Spatial representation tools (e.g., hand-drawn maps, ArcGIS maps, or three-dimensional landscape visualizations) 14

\section{Target audience}

$\begin{array}{rll}\text { Stakeholders involved } & 19 & 45.2 \\ \text { Scientific audiences } & 18 & 42.9 \\ \text { Not stated } & 10 & 23.8 \\ \text { public incl. private sector } & 9 & 21.4 \\ \text { national decision makers } & 2 & 4.8\end{array}$

\section{Monitoring and evaluation of process and outcomes}

Monitoring

$\begin{array}{lll}\text { No } & 41 & 97.6 \\ \text { Yes } & 1 & 2.4\end{array}$

Duration of monitoring

$$
\begin{array}{rll}
\text { Not stated } & 41 & 97.6 \\
\text { One year } & 1 & 2.4
\end{array}
$$

\section{Reason for not monitoring}

Evaluation

Not stated $40 \quad 95.2$

Time or financial constraints $2 \quad 4.9$

$\begin{array}{rrr}\text { No } & 25 & 59.5 \\ \text { Yes } & 15 & 35.7\end{array}$

Method(s) of evaluation

NA $\quad 24 \quad 57.1$

Focus group discussion(s) $6 \quad 14.3$

Interviews $5 \quad 11.9$

Surveys $4 \quad 9.5$

Not stated $4 \quad 9.5$

Qualitative, self-reflexive assessment by participants $2 \quad 4.8$

Expert meeting to investigate possibilities of implementation $\begin{array}{lll}1 & 2.4\end{array}$

Secondary information $1 \quad 2.4$

Observation $11 \quad 2.4$

\section{Reason for evaluation}

$\begin{array}{rll}\text { NA } & 25 & 59.5 \\ \text { Assess usefulness of process } & 9 & 21.4 \\ \text { Provide feedback } & 5 & 11.9 \\ \text { Not stated } & 2 & 4.8 \\ \text { Assess social connection created } & 1 & 2.4 \\ \text { Determine steps going forward } & 1 & 2.4\end{array}$


Assess degree of learning

Assess framings, generalizations, rhetoric of paradigms

Who defined the boundaries and scale of the research?

Researchers $22 \quad 52.4$

Researchers, literature $9 \quad 21.4$

Stakeholders $6 \quad 14.3$

Stakeholders, researchers $4 \quad 9.5$

Stakeholders, researchers and literature $\quad 1 \quad 2.4$

Evidence of outcomes in the short-and long-term

$$
\begin{array}{ccc}
\text { Yes } & 21 & 50.0 \\
\text { No } & 21 & 50.0
\end{array}
$$

Inform future research

$\begin{array}{rcl}\text { No } & 39 & 92.9 \\ \text { Yes } & 3 & 7.1\end{array}$

